2 Lingbi Jiang ${ }^{1}$, Mingming Yang ${ }^{1,3}$, Shihui $\mathrm{He}^{1}$, Zhengyang $\mathrm{Li}^{1}$, Haobin $\mathrm{Li}^{1}$, Ting Niu ${ }^{1}$, Dehuan Xie ${ }^{3}$, Yan

$3 \mathrm{Mei}^{3}$, Xiaodong $\mathrm{He}^{1}$, Lili Wei ${ }^{4}$, Pinzhu Huang ${ }^{4}$, Mingzhe Huang ${ }^{4}$, Rongxin Zhang ${ }^{2,1}$, Lijing Wang ${ }^{*}$,

$4 \quad$ Jiangchao $\mathrm{Li}^{1 *}$

5 Authors' affiliations:

1. Institute of Basic Medical Sciences, School of Life Sciences and Biopharmaceuticals, Guangdong Pharmaceutical University, Guangzhou, 510006, China. maceutical University, Guangzhou, 510006, China.

3. The State Key Laboratory of Oncology in South China, Collaborative Innovation Center for Cancer Medicine, Sun Yat-Sen University Cancer Center, Guangzhou 510060, China.

\title{
*Corresponding author
}

Jiangchao Li, Associate Prof. or Prof. Lijing Wang

Institute of Basic Medical Sciences, School of Life Sciences and Biopharmaceuticals, Guangdong Phar-

maceutical University, Guangzhou, 510006, China.

Address: No. 280 Waihuan Rd. E, Higher Education Mega Center, Guangzhou 510006, China.

Office Phone: 86-20-39352126; E-mail: lijiangchao@gdpu.edu.cn or wanglijing@gdpu.edu.cn

\section{Manuscript Conflict-of-interest Disclosure:}

20 The authors declare no potential conflicts of interest. 


\section{Abstract}

Weight loss and muscle wasting can have devastating impacts on survival and quality of life of patients

with cancer cachexia. Here, we have established a hybrid mouse of $\mathrm{Apc}^{\mathrm{Min} /+}$ mice and MMP12 knockout mice $\left(\mathrm{Apc}^{\mathrm{Min} /+} ; \mathrm{MMP12} 2^{--}\right)$and found that knockout MMP12 can suppress the weight and muscle loss of $\mathrm{Apc}^{\mathrm{Min} /+}$ mice. In detail, we found that interleukin 6 was highly upregulated in the serum of cancer patients and MMP12 was increased in muscle of tumor-bearing mice. Interestingly, the interleukin 6 secreted by tumor cells led to MMP12 overexpression in the macrophages, which further resulted in degradation of insulin and insulin-like growth factor 1 and interruption of glycolipid metabolism. Notably, depletion of MMP12 prevented weight loss of $\mathrm{Apc}^{\mathrm{Min} /+}$ mice. Our study uncovers the critical role of MMP12 in controlling weight and highlights the great potential of MMP12 in the treatment of cancer cachexia.

\section{Keywords:}

MMP12; Macrophage; IL-6; Weight and Muscle loss; Cancer cachexia; Apc ${ }^{\mathrm{Min} /+}$; MMP12--

Running title: 


\section{Introduction}

Many studies have shown that rapid skeletal muscle mass loss is a characteristic of cancer cachexia (CAC)

in colorectal cancer (CRC) patients with advanced cancer stages, which cannot be completely reversed

by conventional nutritional support or drugs therapy (Bonetto et al., 2016; Pettersen et al., 2017; Song et

CAC in recent years and great progress has been made in the diagnosis and treatment of $\mathrm{CRC}$, the mor-

61 the loss of skeletal muscle and adipose tissue when maintained for a long time (Fonseca et al., 2020; 
medical interventions or approved drug therapies that can completely reverse muscle loss caused by CAC,

which brings difficulties to the treatment of chemotherapy drugs (Daou, 2020) (Fonseca et al., 2020).

MMP12 is a matrix protein metalloenzyme, also named macrophage metalloenzyme, from a family of endoproteolytic enzymes whose activities depend on metal ions such as calcium and zinc and can degrade extracellular matrix. It was discovered in a study of tadpole morphological changes during development and is necessary for monocyte recruitment, and it is mainly secreted by inflammatory cells such as monocyte macrophages(Bauters et al., 2013). MMP12 is mainly secreted by M2 macrophages(Han et al., 2018; Hotary et al.; Lee et al., 2016). Reports have demonstrated that MMP12 can decompose most extracellular matrix and vascular components, and has obvious effects on elastic fiber-rich blood vessels, lung, embryonic development, reproduction, and tissue remodeling(Atl1, 2017; Kraen et al., 2019; Langlois et al.; Wagner et al., 2016; Wang et al., 2019; Wetzl et al.). MMP12 is associated not only with smoking-induced emphysema(Kraen et al., 2019) but also with the typing of bone marrow cells and myeloid derived suppressor cells(Qu et al., 2011). As early as 1981, studies reported that MMP12 can specifically degrade insulin(Kettner et al.). In 2014, researchers of Washington University confirmed that MMP12 regulates insulin sensitivity and is positively correlated with insulin resistance(Lee et al., 2016). In 2016, MMP12 was identified as a target for insulin-related treatment of metabolic diseases, and MMP12 promotes insulin resistance and prevents fat expansion under high-fat conditions(Amor and Moreno-Viedma; Bauters et al., 2013). In recent years, some inflammatory cytokines, such as Interleukin 6 (IL-6), monocyte chemoattractant protein-1, tumor necrosis factor, zinc- $\alpha 2$-glycoprotein and pancreatic enzymes, have been shown to be 
al., 2018). IL-6, a multi effect proinflammatory cytokine, is secreted by normal human monocytes, fi-

The IL-6 level has been proposed to be high in patients with skeletal muscle loss (Peixoto da Silva et al.,

2020a). IL-6 levels were increased in tumor tissue and involved in skeletal loss progression in cancer patient (Narsale et al., 2014). IL-6 can directly induce alternative macrophage activation(Ayaub et al.;

Hopkins et al.). And systemic overexpression of IL-6 accelerates CAC muscle loss in Apc ${ }^{\mathrm{Min} /+}$ mice progression of muscular dystrophies, including muscle loss induced by CAC and duchenne muscular dystrophy. Blocking IL-6 receptor may inhibit dystrophic muscle loss and lipolysis by suppressing the downstream Janus kinase/signal transducer and transcription activator (JAK/STAT) pathway to promote muscle regeneration(Hu et al., 2019; Wada et al., 2017). Ville Wallenius et al found that centrally acting IL-6 exerts anti-obesity effects in rodents but does not increase energy expenditure(Franckhauser et al., 2008; Wallenius et al., 2002). IL-6 has been shown to induce insulin resistance(Liaqat et al., 2017). It is well known that insulin affects glucose uptake through the PI3K-AKT-mTOR pathway by binding to

101 insulin receptors(Hopkins et al.). Skeletal muscle is the primary tissue involved in insulin-stimulated glucose uptake. IL-6 mediates glucose intolerance and promotes insulin resistance in skeletal muscle

103 (Deshmukh et al.; Han et al., 2018; Nicholson et al., 2019). Moreover, insulin resistance can promote

104 muscle wasting(Peixoto da Silva et al., 2020b). IL-6 suppresses insulin action through the Signal trans-

105 ducer and activator of transcription 3 (STAT3) pathway, which then may affect the insulin receptor by 
MMP12 in these activated macrophages will be upregulated, degrading insulin and insulin-like growth

1116 derived from cancer cells up-regulates MMP12 in macrophages, which affects skeletal glycolipid metabolism over a long period of time, may resulting in loss of skeletal muscle for a long time.

113 To date, for patients with muscle and weight loss induced by CAC, multimodal interventions including

114 drugs, nutritional support and physical exercise may be a reasonable approach for future research to

115 better understand and prevent loss of muscle (Fonseca et al., 2020). Although several drugs have had

116 positive clinical effects in increasing lean body mass, their effects on body function are limited. There

117 are no effective medical interventions or approved drug therapies that can completely reverse muscle

118 loss caused by CAC, which brings difficulties to the treatment of chemotherapy drugs (Daou, 2020)

119 (Fonseca et al., 2020). Taken together, the combination of MMP12 inhibitors and chemotherapy drugs may bring new challenges and ideas for the treatment of cancer cachexia to improve the quality of life. 


\section{Materials and Methods}

B6.129X-MMP12tm1Sds/J macrophage metalloelastase-deficient (MMP12 $2^{-/}$) mice (no. 004855), with tical University.

\section{2 Genotype identification}

140 We established crossbred mice and genotyped the 3-week-old mice. The polymerase chain reaction prod-

141 ucts were subjected to gel electrophoresis (1.2\%), and a gel imaging system (GboxGyngene system, UK)

142 was used to obtain electrophoresis images (Figure 1-figure Supplement 1B). The details of genotype

143 identification can be found on the website of the Jackson Laboratory https://www.jax.org/strain/004855.

144 2. 3 Mice experiments and Tissue collection

145 Mice were anesthetized by inhalation of carbon dioxide anesthesia, marrow, blood, epididymal white fat,

146 gastrocnemius and soleus muscle and brown back fat were collected. For immunohistochemistry Mice

147 were anesthetized by inhalation of carbon dioxide anesthesia, marrow, blood, epididymal white fat, 
gastrocnemius and soleus muscle and brown back fat were collected. For immunohistochemistry stain-

149 ing analysis, we obtained muscle tissues wax tissue blocks from clinical surgery patients. For serum

150 detection, all fresh clinical blood samples were obtained from the Sun Yat-Sen University Cancer Center,

151 Guangzhou, China. all fresh clinical blood samples were taken individuals undergoing a clinical health

152 individuals and colorectal cancer patients (30-60 years, excluding individuals with diabetes and hyper-

153 thyroidism) and frozen at $-80^{\circ} \mathrm{C}$ until the experiments were performed.

154 2. 4 Antibodies and Reagents:

155 An anti-F4/80 anti-body (Cat: 14-4801-81) was purchased from eBioscience and anti-MMP12 (MA5-

156 24851) were purchased from Thermo Fisher (Thermo Fisher Scientific, Cambridge, Massachusetts,

157 USA). An anti-GAPDH (5174P) and anti- $\beta$-actin (4970S) were purchased from Cell Signaling Technol-

158 ogy Inc (CST). Recombinant mouse MMP-12 protein (3467-MPB-020) was purchased from R\&D Sys-

159 tems, Inc. The MMP12 inhibitor MMP408 (444291) was purchased from Merck Millipore Company.

160 Alexa Fluor-488 donkey antibody (P/N SA11055S) was purchased from Invitrogen (Thermo Fisher Sci-

161 entific, Cambridge, Massachusetts, USA).

162 2. 5 Total RNA extraction and Real-time polymerase chain reaction

163 All tissues from mice were quick-frozen in liquid nitrogen and stored at $-80^{\circ} \mathrm{C}$ until they were dissolved

164 with Trizol (TaKaRa, Guangzhou, China, A161050A). RNA extraction was performed according to the

165 manufacturer's instruction, and the total extracted RNA was reverse-transcribed into cDNA for polymer-

166 ase chain reaction amplification using the real-time polymerase chain reaction SYBR Green kit (TaKaRa,

167 Guangzhou, China). The reverse transcription steps were as follows: denaturation at $94^{\circ} \mathrm{C}$ for 5 minutes;

16840 cycles of denaturation at $94^{\circ} \mathrm{C}$ for 30 seconds, annealing at $60^{\circ} \mathrm{C}$ for 30 seconds, and extension at 
$72^{\circ} \mathrm{C}$ for 30 seconds; $72^{\circ} \mathrm{C}$ for 5 minutes. The mRNA samples were quantified in triplicate. The house-

170 keeping gene GAPDH was used as an internal control to normalize the real-time polymerase chain reac-

171 tion data for each sample of mRNA. All real-time polymerase chain reaction primers were synthesized

172 by Shanghai Sangon Biotechnology Inc., China, and the primer sequences are listed in S Table 1.

173 2. 6 Histological analysis and Hematoxylin and eosin staining

174 Formalin-fixed (10\% neutral buffered formalin), gradient dehydration and paraffin-embedded to obtain

$1753-\mu \mathrm{m}$ tissue sections from mice were subjected to perform the experiments of hematoxylin and eosin

176 staining, immunohistochemical staining and immunofluorescence staining in accordance with the proto-

177 cols. To assess the cross-sectional area of muscle, image J software was used after hematoxylin and eosin

178 staining

1792.7 Immunohistochemistry

180 Tissue sections were dewaxed and incubated with 30\% hydrogen peroxide in methanol and blocked with

181 10\% bovine serum albumin diluted with phosphate buffered saline (PBS). The sections were incubated

182 with primary antibodies against MMP12 $(1: 100)$ at $4^{\circ} \mathrm{C}$ overnight. Finally, the primary antibody-treated

183 sections were incubated with secondary antibody (1:100) horseradish peroxides (HRP) (goat anti-rabbit

$184 \mathrm{IgG}$ ) conjugated with $\mathrm{HRP}$ at $37^{\circ} \mathrm{C}$ for 1hour, stained with 3,3-diaminobenzidine, and counterstained

185 with hematoxylin.

186 2.8 Double immunofluorescence staining

187 Tissue sections were dewaxed and blocked with $10 \%$ bovine serum albumin diluted with PBS. The sec-

188 tions were incubated with a mixture of primary antibodies against MMP12(1:100) and F4/80 (1:100)

189 overnight at $4{ }^{\circ} \mathrm{C}$. The next day, the primary antibody-treated sections were incubated with mixtures of 

scope.

203 Tissue samples (50-80 mg) or cells were homogenized and lysed with radio immunoprecipitation assay

204 buffer (Thermo Scientific, 89900) containing with protease and phosphatase inhibitors, and then the su-

205 pernatants were clarified by centrifugation. Quantitative analysis based on the bicinchoninic acid (BCA)

206 protein assay was used to detect the protein concentration. Denatured proteins in the supernatant were

207 separated by sodium dodecyl sulfate-polyacrylamide gel electrophoresis and transferred to polyvinyli-

208 dene difluoride (Millipore Corporation, Billerica, MA, USA) membranes, blocked with 5\% nonfat milk

209 powder at room temperature, and then incubated with the primary antibodies $(1: 1000)$ overnight at $4{ }^{\circ} \mathrm{C}$.

210 The next day, the protein strips were further incubated with HRP-conjugated anti-rabbit secondary 
211 antibodies (1:5000) and the bands were visualized after exposure to film after incubated with enhanced

212 chemiluminescence detection reagents. These bands were visualized after exposure to film. We used

213 imageJ software to analyze the optical density of the protein band. All experiments were repeated three

214 times.

$215 \quad 2.11$ Cytokine antibody assay

216 Qualitative assessment of 38 cytokines in the supernatants from media for culture (+MC38) or non-cul-

217 ture with MC38 (-MC38) cells was performed with the Ray Bio Mouse Cytokine Antibody Array 5

218 (AAM-INF-1-2, Ray Biotech) according to the provided manufacturer's protocol. The detection proce-

219 dure was as follows: The membranes were blocked by incubation with the blocking buffer. Diluted bio-

220 tin-conjugated anti-cytokine antibodies and HRP-conjugated streptavidin were detected to immuno-

221 complexes. The visualized X-ray film was exposed to chemiluminescence for quantification with ECL

222 chemiluminescence. Semiquantitative data analysis was performed for signal intensity ImageJ, and

223 positive controls were used to normalize the results. Every cytokine to positive control ratio (cytokine

224 density/positive control density) is used to represent the relative content of every cytokine. The cyto-

225 kines and their abbreviations are shown in (Figure 3-figure Supplement 7).

226 2. 12 Oral glucose tolerance test, Insulin tolerance test and Blood glucose level measurement

227 Mice were fasted for 8 hours and then housed overnight. And then, they were given either oral glucose

$228(2 \mathrm{~g} / \mathrm{kg}$ body weight or an intraperitoneal insulin injection $(0.75 \mathrm{IU} / \mathrm{kg})$. The tail vein blood glucose level

229 of mice was measured for tail blood glucose at $0,15,30,45,60,90$, and 120 minutes after treatment.

230 Blood samples were collected at 0,15, 30 and 60, 90, and 120 minutes for glucose measurement in tail 
vein blood with a blood glucose meter (Johnson \& Johnson) at the specified time points. All blood glucose levels were performed using the glucose meters.

234 The levels of total cholesterol (TC), total triglycerides (TG), high density lipoprotein cholesterol (HDL-

235 C) and low density lipoprotein cholesterol (LDL-C) were determined according to the manufacturer's

236 protocols. The assay kits all were purchased from Jiancheng (Nanjing, China).

237 2. 14 Cell culture

238 The RAW264.7 cell line, MC38 cell line and CT26 cell line were purchased from the American Typical

239 Culture Collection (ATCC) and cultured according to international standard protocols. All cell lines were

240 maintained in Dulbecco's Modified Eagle's Medium (DMEM, Thermo Scientific HyClone, Beijing,

241 China) $+10 \%$ fetal bovine serum (FBS, HyClone) $+1 \%$ penicillin (HyClone)/streptomycin (HyClone)

242 The RAW 264.7 cell line, MC 38 cell line and CT26 cell line were cultured in DMEM. All cell lines in

243 the experiments were incubated with a mixture of $95 \%$ air and $5 \% \mathrm{CO}_{2}$.

244 2. 15 Co-culture experiment

245 All cells were grown in DMEM+10\% FBS+10\% penicillin-streptomycin. The co-culture of RAW264.7

246 and MC38/CT26 cells was seeded into performed using a chamber with filter inserts (pore size,0.4 $\mu \mathrm{m}$ )

247 in 6-well dishes (Corning, NY, USA). All cell lines could not pass to the filter because the pore size of

248 the filter was smaller than the diameter of cell lines. RAW264.7 cells non co-cultured with MC38/CT26

249 cell lines (-MC38/CT26) were used as the negative controls. MC38/CT26 cell lines (control, 1x104, 3x10

$\left.2505 \times 10^{4}\right)$ were seed in upper chamber, while RAW264.7cells $\left(1-2 \times 10^{5}\right)$ were seed in the lower chamber.

251 We can separate physically RAW264.7 cells or MC38/CT26 cell lines to obtain RAW264.7 
(+MC38/CT26) cells in lower chamber. The RAW264.7 cells were homogenized and lysed with radio

253 immunoprecipitation assay buffer to quantitative analysis and then subjected to western bloting.

255 The Interleukin 6 (IL-6) freeze-dried powder was purchased from Pepertech (216-16) and was dissolved

256 in trehalose-bovine serum albumin aqueous solution. RAW264.7 cells $\left(1-2 \times 10^{5}\right)$ were seeded into 6-well

257 plates and treated with increasing different doses of IL-6 (+IL-6, 0, 2, 5 10,30ng/ ml) for 72hours. Next,

258 RAW264.7 cells $\left(1-2 \times 10^{5}\right)$ were treated continuously with IL-6(+IL-6, $\left.30 \mathrm{ng} / \mathrm{ml}\right)$ for $0,3,6$, and 9hours.

259 Cells incubated with fresh media were used as the untreated (-IL-6) negative controls. Finally, western

260 blotting was used to quantify MMP12 in RAW264.7 cells under different conditions.

2612.18 Isolation of primary peritoneal macrophages

24-week-old WT and $\mathrm{Apc}^{\mathrm{Min} /+}$ mice were sterilized with $75 \%$ ethanol after cervical dislocation. The

263 mouse abdomen was opened from the peritoneum, and $5 \mathrm{~mL}$ fatal bovine serum was injected with a

264 syringe, which was allowed to remain inside the abdomen for 5 minutes, with gentle massaging for $30 \mathrm{~s}$.

265 The peritoneal fluid was collected, and this fluid was transferred to a $15 \mathrm{~mL}$ sterile tube to obtain perito-

266 neal macrophages. After centrifugation $\left(4^{\circ} \mathrm{C}, 1000 \mathrm{rpm}\right)$ for 10 minutes, the supernatant was removed,

267 and the collected cells were resuspended in Dulbecco's Modified Eagle's Medium. The resuspended cells

268 were cultured in a petri dish for 2 hours $\left(37^{\circ} \mathrm{C}\right)$, and the primary peritoneal macrophages were prepared

269 from the remaining adherent cells after the medium was removed.

2702.19 MMP12 and Peptide experiments:

271 Recombinant mouse MMP-12 protein (3467-MPB-020) was purchased from R\&D Systems, Inc. Ac-

272 cording to the instructions, dissolve MMP12 in a buffer containing $50 \mathrm{mM}$ Tris, $10 \mathrm{mM} \mathrm{CaCl} 2,150 \mathrm{mM}$ 
$273 \mathrm{NaCl}, 0.05 \%$ (w/v) Brij-35, $5 \mu \mathrm{M} \mathrm{ZnCl}_{2}$, pH 7.5 at a concentration of $250 \mathrm{ug} / \mathrm{ml}$. Insulin polypeptide

274 and insulin-like factor polypeptide were synthesized by ChinaPeptides Co., Ltd.

275 The fluorescent peptide sequence:

276 (1) Insulin:5-FAM-NQHLCGSHLVEALYLVCGERGFFYTPK(Dabcyl);

277 (2) insulin-like growth factor 1: 5-FAM-GPETLCGAELVDALQFVCGDRGFYFNK(Dabcyl). Ac-

278 cording to the instructions, the peptide freeze-dried powder was dissolved in $25 \%$ ACN and $75 \%$

$\mathrm{ddH}_{2} \mathrm{O}$ solvent at a concentration of $1 \mathrm{mg} / \mathrm{ml}$.

280 The two experiments are as follows: (1) Fluorescence intensity: After mixed incubation of MMP12 and

281 peptide $\left(37^{\circ} \mathrm{C}, 2\right.$ hours $)$, the fluorescence intensity was measured with a fluorescence microplate reader.

282 (2) MS Analysis Report: After the MMP12 and peptide were mixed and incubated, the lower liquid af-

283 ter being filtered by a 34KD filter is subjected to Electrospray Ionization Mass Spectrometry (IMS) to

284 detect its characteristic peaks. The experimental conditions are: Ion Source: ESI, Capillary (KV): \pm

285 (2500 3000), Desolvation(L/hr):800, Desolvation Temp:450 C, Cone(V): 30 50, Run Time: $1 \mathrm{~min}$.

286 2. 20 Mice administration

287 All 17-week-old $\mathrm{Apc}^{\mathrm{Min} /+}$ mice were randomly divided into three groups (five mice in each group). A

288 group of $\mathrm{Apc}^{\mathrm{Min} /+}$ mice were administered intragastric with MMP12 inhibitor (MMP408) at a dose of

$2895 \mathrm{mg} / \mathrm{kg}$, and the other group was intraperitoneally administered with $5-\mathrm{FU}(30 \mathrm{mg} / \mathrm{kg})$ combined with a

290 dose of intragastric administration of MMP408. At the same time, $\mathrm{Apc}^{\mathrm{Min} /+}$ mice injected with normal

291 saline intraperitoneally served as a control group. The body weight was weighed by the administration

292 every 2 days and after this continued for 10 days, the final weight change from the initial body weight

293 was calculated. 
295 All mouse organ ratios represented the percentage of the organs/tissues weight compared to the body 


\section{Results}

\section{1 Knockout MMP12 can suppress weight and muscle loss in $\mathrm{Apc}^{\mathrm{Min} /+}$ mice}

To investigate the weight dynamics of the mice, we determined the mouse body weight by retroactive

(Figure 1A). Surprisingly, in comparison to the $\mathrm{Apc}^{\mathrm{Min} /+}$ mice control, the body weight of $\mathrm{Apc}^{\mathrm{Min} /+}$;

329 WT mice, the WAT-to-body weight ratio in $\mathrm{Apc}^{\mathrm{Min} /+}$ mice decreased and the weight ratio of $\mathrm{Apc} \mathrm{Min} /+^{\text {; }}$

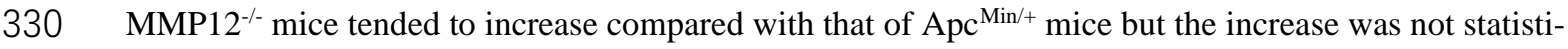

331 cally significant (Figure 1D). However, a significant increase of approximately $4.5 \%$ in the muscle-tobody weight ratio was observed in $\mathrm{Apc}^{\mathrm{Min} /+} ; \mathrm{MMP}_{2}{ }^{-/}$mice compared with $\mathrm{Apc}^{\mathrm{Min} /+}$ mice (Figure 1E).

333 To further confirm the histological changes of WAT (Figure 1F) and muscle area (Figure 1H) in the

334 four mice group at 24-week-old, we performed hematoxylin and eosin staining to assess the histologi-

335 cal area by the ImageJ software (Figure $1 \mathrm{~F}, \mathrm{H})$. We observed the fat area is larger in MMP12 $2^{-\digamma}$ mice 
compared with WT mice, but there has no difference between $\mathrm{Apc}^{\mathrm{Min} /+}$ mice and $\mathrm{Apc}{ }^{\mathrm{Min} /} ; \mathrm{MMP}^{-/-}$

337 mice (Figure 1G). The H\&E staining of muscle to show that the area of $\mathrm{Apc}^{\mathrm{Min} /+}$; MMP12 $2^{-/}$mice is es-

timated to be approximately 1-2-fold larger than $\mathrm{Apc}^{\mathrm{Min} /+}$ mice (Figure 1I). Meanwhile, no difference in

341 mice at CAC stage, but not in WT mice.

\subsection{MMP12 is upregulated in muscle tissue and peritoneal macrophages of $\mathrm{Apc}^{\mathrm{Min} /+}$ mice}

343 To confirm whether MMP12 is expressed in muscle tissue, we use immunohistochemical staining, im-

344 munofluorescence staining and western immunoblotting to detect the expression of MMP12 in muscle.

345 The immunohistochemistry results proved that MMP12 positive staining was expressed not only in

346 skeletal muscles from clinical individuals (Figure 2A, Figure 2 -figure Supplement 3B), but also in WT

347 mice (Figure 2B $)$. In order to investigate why the reduction in muscle loss caused by knocking out

348 MMP12 only occurred after tumor-bearing mice and not in WT mice, furthermore, we used immuno-

349 histochemistry methods to detect MMP12 expression in muscle from 24-week-old WT mice and

$350 \mathrm{Apc}^{\mathrm{Min} /+}$ mice (Figure 2C). The results of immunohistochemical staining showed that MMP12-positive

351 staining was increased in the muscle of $\mathrm{Apc}^{\mathrm{Min} /+}$ mice compared with that in WT mice at 24-weeks old

352 by image $\mathrm{J}$ (Figure 2D). Because MMP12 is mainly secreted by macrophages (Lee et al., 2014a; Lee et

353 al., 2014b), next, we performed double immunofluorescence (IF) to detect the expression of macro-

354 phages and MMP12 in muscle and found that the F4/80 and MMP12 markers were colocalized in mice

355 (Figure 2E). Quantitative PCR (qPCR) revealed that a tendency towards higher MMP12 mRNA levels

356 in peritoneal macrophages (as described in the Materials) was seen in $\mathrm{Apc}^{\mathrm{Min} /+}$ mice (Figure 2F), which 
358 MMP12 level by enzyme-linked immunosorbent assay and found that the MMP12 levels in 9-, 15-, and

MMP12 is increased in skeletal muscle tissue and peritoneal macrophages of $\mathrm{Apc}^{\mathrm{Min} /+}$ mice, but no dif-

\section{3 Tumor cells can secrete IL-6}

364 Previous studies have shown that interleukin 6 (IL-6) is one of the cytokines predictive muscle loss induced by CAC(Bonetto et al., 2012; Kim et al., 2013; Mahadik and Sujata, 2013; Mauer et al., 2014), it

can accelerate muscle loss indued by CAC. And tumor cells are an important source of IL-6(Carson and

Baltgalvis, 2010b; Han et al., 2018; Pettersen et al., 2017). The clinical literature data also suggested that among many CAC-muscle loss patients who lost weight and were close to death, IL-6 was almost the

related to muscle loss, is caused by tumors (Carson and Baltgalvis, 2010b). We observed that the clinical

371 colorectal cancer patients had significantly higher serum IL-6 levels than the normal healthy group (Fig-

$372 \underline{\text { ure } 3 \mathrm{~A}}$ ). In vivo, a similar trend was found in $\mathrm{Apc}^{\mathrm{Min} /+}$ mice, and serum IL-6 levels in Apc ${ }^{\mathrm{Min} /+}$ mice were

373 significantly increased compared with WT mice at 15-24-week-old (Figure 3B). We demonstrated that

374 the IL-6 mRNA levels were higher in intestinal tumors of $\mathrm{Apc}^{\mathrm{Min} /+}$ mice than in normal intestinal epithe-

375 lium of WT mice by qPCR (Figure 3C). Previous study reported MC38 cells and CT26 cells all can secret

376 IL-6(Li et al., 2018). Therefore, tumor cells can be the source of IL-6. In vitro, we used protein microar-

377 rays to detect inflammatory factors in the supernatant of mouse colorectal carcinoma MC38 cell lines 
and the results showed that IL-6 expression was higher in the supernatant after cultured with MC-38 cells

(Figure 3D, E). So, tumor cells can secrete IL-6.

\section{4 Tumor-derived IL-6 can upregulate MMP12 in macrophage}

381 Because some previous studies reported that IL-6 may not directly lead to muscle loss in CAC(Carson and Baltgalvis, 2010a; Franckhauser et al., 2008). IL-6 in the tumor microenvironment may be an important determinant of alternative macrophage activation and induce macrophage M2 polarization and

384 M2 macrophages can produce MMP12(Suzuki et al., 2017; Wang et al., 2018). Taken together, we spec-

385 ulated whether tumors regulate macrophage MMP12 by secreting IL-6 to affect muscle loss. To uncover

386 the underlying mechanism communication between tumor-derived IL-6 and macrophages, we performed

387 cell experiments in vitro (as described in the Materials). Mouse macrophage RAW264.7 cells co-cultured

388 with mouse colorectal cancer MC38 cells (CT 26 cells) for 72hours to detect macrophage MMP12 by

389 western blotting (Figure 4A) and the results confirmed that RAW264.7 cells exhibited increased MMP12

390 expression as the number of MC38 cells increased, with RAW264.7 cells cultured alone as the negative

391 control group (Figure 4B, C). Similar trends were observed in CT26 cells (Figure 4D, E). We further

392 treated RAW264.7 cells with IL-6 in different methods. RAW264.7 cells were seeded into 6-well plates

393 and treated with increasing doses of IL-6 $(0,2,510,30 \mathrm{ng} / \mathrm{mL})$ for $72 \mathrm{~h}$. Next, RAW264.7 cells were

394 treated continuously with IL-6 (30 ng/ml) for 0, 3, 6, and 9hours. Cells incubated with fresh media were

395 used as the untreated negative controls (Figure 4F). We found that within a certain concentration range

$396(<30 \mathrm{ng} / \mathrm{ml})$, as the IL-6 dose increased, the expression of MMP 12 in RAW264.7 cells also increased

397 when treated with IL-6 (Figure 4G, H). Next, the expression of MMP12 in RAW264.7 increased as the

398 stimulation time prolonged when the RAW264.7 cells treated with IL-6(30ng/ml) (Figure 4I, J). 
Meanwhile, immune gene data proved that IL-6 receptor (IL-6R) is highly expressed on myeloid cells,

\section{5 MMP12 can degrade insulin and insulin-like growth factor-1}

404 The present results have proved that tumor-derived IL-6 can up-regulate MMP12 in macrophages.

405 Knockout of MMP12 can reduce muscle loss in $\mathrm{Apc}^{\mathrm{Min} /+}$ mice. Recently, it has been demonstrated that

406 insulin and insulin-like growth factor 1(IGF-1) have complex anabolic effects and are important regula-

407 tors of muscle remodeling that can mediate muscle atrophy(Baker Rogers et al., 2020; Dev et al., 2019;

408 Han et al., 2019; Masi and Patel, 2020; Takayama, 2019). Moreover, Jung-Ting Lee proposed that

409 MMP12 expression significantly promoted insulin resistance and that insulin may be regulated by resi-

410 dent macrophages(Lee et al., 2014a). To understand the molecular mechanism underlying muscle loss

411 by macrophage MMP12, we further examined the relationship between MMP12 and insulin (IGF-1)

412 which affects muscle loss. Firstly, after the labeled insulin polypeptide is incubated with serum, the ab-

413 sorbance increases $(\lambda=488 \mathrm{~nm})$ (Figure 5A). Because IGF-1 is similar in structure to insulin, further-

414 more, we verified the relationship between fluorescently labeled insulin (IGF-1) and MMP12, and

415 measured its fluorescence intensity and characteristic peak changes (Figure 5B). We found that when

416 the dose of insulin fluorescent peptide is constant, the more MMP12 protein, the stronger the fluores-

417 cence intensity. Similar Tendencies were observed in the IGF-1(Figure 5C). The qualitative results of

418 electrospray ionization mass spectrometry showed that the characteristic peak of insulin fluorescent

419 peptide $(\mathrm{m} / \mathrm{z}=436.99)$ disappeared after incubation with MMP12 protein (Figure 5-figure Supplement 
IGF-1. It seems that the degradation of MMP 12 to IGF-1 is stronger than that of insulin.

\subsection{MMP12 inhibitor can rescue weight loss of $\mathrm{Apc}^{\mathrm{Min} /+}$ mice}

It is reported that insulin and insulin-like growth factor 1 can indeed affect the muscle loss caused by combination group (+MMP408+5-FU), when compared with the MMP12 inhibitor group alone (+ 


\section{Discussion}

442 Researches on weight loss have received more and more attention in many fields, such as diabetes, ab-

443 normal thyroid metabolism, weight control, etc, among which, muscle loss caused by malnutrition sim-

444 ilar to cancer cachexia (CAC) is more worrying. More than four-fifths of patients with CAC die from

445 extreme loss of body weight and skeletal muscle. Our study suggested that MMP12 plays a new role in

446 controlling weight and muscle loss and inhibiting MMP12 can reverse the body weight reduction with

447 CAC. In details, the major findings of our study are as follows: (1) MMP12 promotes weight loss and

448 accelerates the deterioration of CAC. The loss of weight and muscle induced by CAC was reduced in

$449 \mathrm{Apc}^{\mathrm{Min} /+}$ by MMP12 knockout. (2) In vivo, MMP12-positive immunostaining was found in muscle of

450 human and mice. MMP12 was co-labeled with macrophages in the muscle tissue in situ. Importantly,

451 MMP12 positive staining was substantially increased in the muscle and peritoneal macrophages from

$452 \mathrm{Apc}^{\mathrm{Min} /+}$ mice compared with those from wild type (WT) mice. (3) Clinically, serum interleukin 6 (IL-

453 6) increased in cancer patients. A similar increasing trend was found in serum and tumor tissues of

$454 \mathrm{Apc}^{\mathrm{Min} /+}$ mice compared to those from WT mice. Crucially, IL-6 has been shown to be directly secreted

455 by MC38 tumor cells. (4) In vitro, we proved that tumor cells have a positive relationship with MMP12

456 secreted by macrophages. At the cellular level, we found for the first time that macrophages can be

457 stimulated and regulated by IL-6, and the level of MMP12 in macrophages was up-regulated. (5) Un-

458 derlying mechanism, MMP12 can degrade insulin and insulin-like growth factor 1. In our study, the

459 degradation effect of MMP12 on insulin-like growth factor 1 was proved for the first time, and it was

460 found that the degradation effect of MMP12 was stronger than that of insulin. (6) Inhibiting MMP12

461 prevent weight loss in $\mathrm{Apc}^{\mathrm{Min} /+}$ mice at CAC stage. In summary, the present study uncovered a novel 
mechanism that MMP12 promotes weight and muscle loss. The crosstalk between tumor cells and mac-

rophages is that MMP12 is upregulated by tumor cell-derived IL-6 and MMP12 can degrade insulin

465 Weight and muscle loss induced by CAC is main cause of death in cancer patients worldwide. The clinmuscle.

473 As a kind of matrix metalloproteinase family, MMP12 is also called macrophage elastase. It was previ-

474 ously reported that MMP12 can decompose various extracellular matrix components and vascular com-

475 ponents, and MMP12 is involved in tumor cell invasion and metastasis. In 2014, Lee Jung-Ting had 476 explored the role of MMP12 in white adipose tissue expansion on high-fat feeding(Jung-Ting et al.,

477 2014), while the function of MMP12 under the lack of nutrition yielded has not been studied. We firstly

478 tried to build a model with tumor-bearing environment lacking nutrition in $\mathrm{Apc}^{\mathrm{Min} /+}$ mice hybridized with

479 MMP12-/ mice. Unexpectedly, under the condition of tumor-bearing mice, knocking out MMP12 caused

480 a decrease in muscle loss, but not affect white adipose tissue.

481 A mRNA analysis of the data got from The Cancer Genome Atlas (TCGA) for GTEx, Illumina, Bi- 
study, we focus on the liver, muscle and fat tissues. We weighed these mice tissues at 24 -weeks old,

484 and performed histological evaluation using H\&E staining. The liver weight has difference between

$\mathrm{Apc}^{\mathrm{Min} /+}$ mice and $\mathrm{Apc}^{\mathrm{Min} /+} ; \mathrm{MMP}^{-/-}$mice (Figure 1-figure Supplement $4 \mathrm{~A}$ ), however, H\&E staining

(Figure 1-figure Supplement 4B). Similarly, knocking out MMP12 in Apc ${ }^{\mathrm{Min} /+}$ mice did not cause 
IL-6 is mainly secreted by a variety of immune cells and is also highly expressed in a variety of cancer

511 rived chemokine (KC) which can recruit macrophages(Barcelos et al., 2004; Engin, 2017; Wang et al.,

512 2011). But unfortunately, our experiments have shown that only increased at mRNA levels of intestinal

513 tumors in $\mathrm{Apc}^{\mathrm{Min} /+}$ mice at CAC stage but serum MCP1did not change at the CAC stage in $\mathrm{Apc} \mathrm{Min} /+^{-}$

514 mice (Figure 3-figure Supplement 5A, B). There was no difference in serum KC and KC mRNA levels

515 in late tumors in mice (Figure 3-figure Supplement 5C, D). Similarly, clinically, serum KC did not dif-

516 fer between normal healthy individuals and colorectal cancer patients (Figure 3-figure Supplement 5E).

517 In summary, we suspected that there may be a possibility that MCP1 and KC can also cooperate with

518 IL-6 to recruit macrophages, thereby activating alternative macrophages to polarize M2 macrophages,

519 resulting in MMP12 secretion. The above results suggested that in the period of CAC, the key is that

520 IL-6 secreted by tumor cells plays a major role(Baltgalvis et al., 2008). In Table 2.

521 we summarized the research on IL-6 on body weight and muscle loss, which mostly demonstrated that

522 IL-6 may have indirect effect on body weight and muscle. Especially, Kristen A Baltgalvis pointed out

523 knocking out IL-6 can reduce muscle consumption in $\mathrm{Apc}^{\mathrm{Min} /+}$ mice(Baltgalvis et al., 2008). 
524 The crosstalk between tumors and inflammatory factors is well known(Talbert et al., 2018b; Zhang et

525 al., 2008). We use co-culture experiments in MC38 cell lines and CT26 with RAW264.7 cell lines to

526 demonstrate that macrophage MMP12 increase treatment with IL-6. We speculated that this is caused by

527 the IL-6 secreted by tumor cells, and we firstly proved that IL-6 can directly upregulate macrophage

528 MMP12. However, we did not determine whether the IL-6 produced by macrophages acts on macro-

529 phages themselves. Similarly, we have not explored whether other cytokines secreted by tumors or mac-

530 rophages themselves play a synergistic or indirect role along with IL-6.

531 In present study, we used fluorescence intensity measurement and ionization mass spectrometry meth-

532 ods to prove that insulin and IGF-1 can indeed be degraded by MMP12, but the specific sites and

533 amino acids where insulin and IGF-1 were broken have not been further proved. At the same time, we

534 could not prove to completely rule out whether MMP12 itself generates characteristic peaks from frac-

535 ture (Figure 5-figure Supplement 2A, B).

536 MMP12, as a macrophage matrix metalloproteinase, has been repeatedly reported to degrade insulin

537 and affect insulin sensitivity. We verified MMP12 can degrade insulin or IGF-1 in vitro, which is con-

538 sistent with the previous study(Kettner et al.). As the two key hormones in tumor microenvironment,

539 insulin resistance is correlated with in insufficient insulin, lack of insulin receptor, or decreased insulin

540 sensitivity, which will reduce the uptake of glucose in organs, which suggests that MMP12 is closely

541 related to glycolipid metabolism, leading to the loss of skeletal muscle and adipose tissue(Baker Rogers

542 et al., 2020; Dev et al., 2019; Han et al., 2019; Masi and Patel, 2020; Takayama, 2019). The insulin kits

543 and insulin tolerance test and oral glucose tolerance test results showed that the knocking out MMP12

544 in $\mathrm{Apc}^{\mathrm{Min} /+}$ mice may reduce insulin levels or increase insulin sensitivity, reversing insulin resistance 
545 (Figure 5-figure Supplement 6A-H), but is not related to basic function of islets according to H\&E

546 staining and IHC staining (Figure 5-figure Supplement 4E-H). We tested four blood lipid levels with

547 the kit, and the results showed that when $\mathrm{Apc}^{\mathrm{Min} /+}$ mice were knocked out MMP12, total triglycerides

548 decreased in the early and middle stages, but high density lipoprotein cholesterol increased in all age

549 groups, total cholesterol and low density lipoprotein cholesterol not changed across the 4 groups (Fig-

550 ure 5-figure Supplement 6I-L). So, does IL-6 regulating MMP12 help restore muscle loss caused by

551 cachexia? Clinical inhibiting IL-6 may reduce CAC patients with weight loss. However, long-term

552 treatments with high-dose IL-6 may cause additional side effects, such as exacerbating CAC resulting

553 in more muscle loss(Wada et al., 2017). After all, IL-6 acts on muscles indirectly. Surprisingly,

554 MMP12, as the downstream of IL-6, can significantly suppress weight loss when being specifically in-

555 hibited in mice, although the effect is not more obvious after combined treatment with the classic colo-

556 rectal cancer chemotherapy drug 5-FU. Clinically, suppressing MMP12 may reduce the possibility of

557 insulin degradation, suggesting that our findings may as a method to treat directly glucose deficiency,

558 CAC and complications of CAC. It will not only provide a new direction for reducing the blood glu-

559 cose and blood lipid levels of cancer patients but also bring new research ideas for the clinical treat-

560 ment of diabetes caused by insulin deficiency.

561 In summary, our results identified that knocking out MMP12 in $\mathrm{Apc}^{\mathrm{Min} /+}$ mice significantly reduced mus-

562 cle loss caused by CAC. We determined a positive correlation with between tumor-derived IL-6 and

563 macrophage MMP12 in colorectal cancer. MMP12 can degrade insulin and IGF-1, reversing the insulin

564 resistance in CAC to regulate tumor glycolipid metabolism. Therefore, MMP12 is a double-edged sword 

treatment of clinical patients with weight loss.

\section{Authors' Contributions}

568 Conceptualization: Jiangchao Li, Lijing Wang, Lingbi Jiang

569 Methodology: Jiangchao Li, Lijing Wang, Lingbi Jiang,

570 Software: Lingbi Jiang

571 Validation: Lingbi Jiang, Mingming Yang, Ting Niu

572 Formal analysis: Jiangchao Li, Lingbi Jiang

573 Investigation: Jiangchao Li, Lingbi Jiang,

574 Resources: Zhengyang Li, Lili Wei, Haobin Li, and Ting Niu, Mingzhe Huang, Pinzhu Huang

575 Data curation: Lingbi Jiang, Jiangchao Li

576 Writing - original draft preparation: Lingbi Jiang, Jiangchao Li,

577 Writing - review \& editing: Visualization; Jiangchao Li, Lijing Wang, Yan Mei, Rongxin Zhang, Dehuan

578 Xie, Yan Mei

579 Supervision; Jiangchao Li, Lijing Wang,

580 Project administration; Lingbi Jiang and Shihui He, Zhengyang Li, Xiaodong He

581 Funding acquisition: Jiangchao Li, Lijing Wang, Rongxin Zhang. This work was supported by grants

583 to Lijing Wang and 81872320 to Rongxin Zhang). The funding source involves research design, data

584 collection and interpretation, and now it is decided to submit the work for publication. 


\section{Acknowledgments}

587 We thank technician Dr. Hao Chen for their help in clinical sample collection. We appreciate that Prof.

588 Ming Li gave us advices for this study. We would also like to thank Jingzhou Xie, Lixun Huang, Yongjia

589 Zheng, Yiting Zhang, Junwei Ye, Qianhui Ma, Jiena Liu and Xiaoyang Chen for their help with animal

590 experiments.

\section{Ethics Statement for Human Subjects Research or Animal Experimentation}

592 All mouse experimental protocols were approved by the animal experimental ethics committee of Guang-

593 dong Pharmaceutical University. The animal ethics approval number was gdpulac2019019. All tests were

594 carried out with the approval of the Guangdong Medical Laboratory Animal Center, Guangzhou, China.

595 All experiments for clinical patients in this study were obtained by the approval of the Guangzhou Human

596 Research Ethics Committee, Provincial First Affiliated Hospital of Guangdong Pharmaceutical Univer-

597 sity, China. The clinical ethics approval number was EC-AF-019.

598

599

600

601

602

603

604

605

606 


\section{References}

608 Amor, M., and Moreno-Viedma, V.J.M.M. Identification of Matrix Metalloproteinase-12 as a

609 Candidate Molecule for Prevention and Treatment of Cardiometabolic Disease. 22.

610 PMID: 27385318

611 Atlı, Ö. (2017). Matrix metalloproteinases are possible targets in monocrotaline-induced 612 pulmonary hypertension: investigation of anti-remodeling effects of alagebrium and everolimus.

613 17, 8-17. PMID: 27182612

614 Ayaub, E.A., Dubey, A., Imani, J., Botelho, F., Kolb, M.R.J., Richards, C.D., and Ask, K.J.S.R.

615 Overexpression of OSM and IL-6 impacts the polarization of pro-fibrotic macrophages and the

616 development of bleomycin-induced lung fibrosis. 7, 13281. PMID: 29038604

617 Baker Rogers, J., Syed, K., and Minteer, J.F. (2020). Cachexia. In StatPearls (Treasure Island FL: (c)

618 2020, StatPearls Publishing LLC.). PMID: 29262118

619 Baltgalvis, K.A., Berger, F.G., Peña, M.M.O., Mark Davis, J., White, J.P., and Carson, J.A. (2010).

620 Activity level, apoptosis, and development of cachexia in Apc(Min/+) mice. Journal of applied

621 physiology (Bethesda, Md : 1985) 109, 1155-1161. PMCID: PMC2963323

622 Baltgalvis, K.A., Berger, F.G., Pena, M.M., Davis, J.M., Muga, S.J., and Carson, J.A. (2008).

623 Interleukin-6 and cachexia in ApcMin/+ mice. Am J Physiol Regul Integr Comp Physiol 294,

624 R393-401. DOI: 10.1152/ajpregu.00716.2007

625 Baracos, V.E., Martin, L., Korc, M., Guttridge, D.C., and Fearon, K.C.H. (2018). Cancer-associated

626 cachexia. Nature Reviews Disease Primers 4, 17105. DOI: $\underline{10.1038 / \mathrm{nrdp} .2017 .105}$

627 Barcelos, L.S., Talvani, A., Teixeira, A.S., Cassali, G.D., Andrade, S.P., and Teixeira, M.M. (2004).

628 Production and in vivo effects of chemokines CXCL1-3/KC and CCL2/JE in a model of

629 inflammatory angiogenesis in mice. Inflammation research : official journal of the European

630 Histamine Research Society [et al] 53, 576-584. DOI: 10.1007/s00011-004-1299-4

631 Bauters, D., Van Hul, M., and Lijnen, H.R. (2013). Macrophage elastase (MMP-12) in expanding

632 murine adipose tissue. Biochimica et Biophysica Acta (BBA) - General Subjects 1830, 2954-

633 2959. DOI: 10.1016/j.bbagen.2012.12.024 
Bing, C. (2011). Lipid mobilization in cachexia: mechanisms and mediators. Current opinion in

637 (2012). JAK/STAT3 pathway inhibition blocks skeletal muscle wasting downstream of IL -6 and in

638 experimental cancer cachexia. Am J Physiol Endocrinol Metab 303, E410-E421.

\section{PMCID: $\underline{\text { PMC3423125 }}$}

640 Bonetto, A., Rupert, J.E., Barreto, R., and Zimmers, T.A. (2016). The Colon-26 Carcinoma Tumor-

641 bearing Mouse as a Model for the Study of Cancer Cachexia. Journal of visualized experiments :

642 JoVE, 54893. PMCID: PMC5226332

643 Bray, F., Ferlay, J., Soerjomataram, I., Siegel, R.L., Torre, L.A., and Jemal, A. (2018). Global cancer 644 statistics 2018: GLOBOCAN estimates of incidence and mortality worldwide for 36 cancers in 185

645 countries. CA: a cancer journal for clinicians 68, 394-424. DOI: 10.3322/caac.21492

646 Brody, H. (2015). Colorectal cancer. Nature 521, S1. DOI: 10.1038/521S1a

647 Carson, J.A., and Baltgalvis, K.A. (2010a). Interleukin 6 as a key regulator of muscle mass during

648 cachexia. Exerc Sport Sci Rev 38, 168-176. DOI: 10.1097/JES.0b013e3181f44f11

649 Carson, J.A., and Baltgalvis, K.A. (2010b). Interleukin 6 as a key regulator of muscle mass during

650 cachexia. Exerc Sport Sci Rev 38, 168-176. PMCID: $\underline{\text { PMC3065300 }}$

651 Center, M.M., Jemal, A., Smith, R.A., and Ward, E. (2009). Worldwide variations in colorectal

652 cancer. CA: a cancer journal for clinicians 59, 366-378. DOI: 10.3322/caac.20038

653 Daou, H.N. (2020). Exercise as an anti-inflammatory therapy for cancer cachexia: a focus on

654 interleukin-6 regulation. American journal of physiology Regulatory, integrative and comparative

655 physiology 318, R296-R310. DOI: 10.1152/ajpregu.00147.2019

656 Deshmukh, Biology, A.S.J.H.M., and Investigation, C. Insulin-stimulated glucose uptake in healthy 657 and insulin-resistant skeletal muscle. DOI: $10.1515 / \mathrm{hmbci-2015-0041}$ 
Dev, R., Del Fabbro, E., and Dalal, S. (2019). Endocrinopathies and cancer cachexia. Current

666 J., Bosch, F., and Smith, U. (2008). Overexpression of II6 leads to hyperinsulinaemia, liver

667 inflammation and reduced body weight in mice. Diabetologia 51, 1306-1316.

668 DOI: $10.1007 / \mathrm{s} 00125-008-0998-8$

669 Han, J., Meng, Q., Shen, L., and Wu, G. (2018). Interleukin-6 induces fat loss in cancer cachexia by 670 promoting white adipose tissue lipolysis and browning. Lipids Health Dis 17, 14-14.

671 PMCID: PMC5771021

672 Han, X., Møller, L.L.V., De Groote, E., Bojsen-Møller, K.N., Davey, J., Henríquez-Olguin, C., Li, Z., 673 Knudsen, J.R., Jensen, T.E., Madsbad, S., et al. (2019). Mechanisms involved in follistatin-induced 674 hypertrophy and increased insulin action in skeletal muscle. J Cachexia Sarcopenia Muscle 10, 675 1241-1257. PMCID: PMC7663972

676 Herremans, K.M., Riner, A.N., Cameron, M.E., and Trevino, J.G. (2019). The Microbiota and Cancer 677 Cachexia. International journal of molecular sciences 20. PMCID: PMC6940781

678 Hopkins, B.D., Chantal, P., Du, X., G., W.D., Xiang, L., David, W., C., A.S., D., G.M., Cindy, H., and 679 Nature, L.M.R.J. Suppression of insulin feedback enhances the efficacy of PI3K inhibitors.

680 PMCID: $\underline{\text { PMC6197057 }}$

681 Hotary, K.B., Allen, E.D., Brooks, P.C., Datta, N.S., Long, M.W., and Cell, S.J.W.J. Membrane Type I 682 Matrix Metalloproteinase Usurps Tumor Growth Control Imposed by the Three-Dimensional 683 Extracellular Matrix. 114, 0-45. DOI: 10.1016/s0092-8674(03)00513-0 
684

685

686

687

688

689

690

691

692

693

694

695

696

697

698

699

700

701

702

703

704

705

706

707

708

709

710

Hu, W., Ru, Z., Zhou, Y., Xiao, W., Sun, R., Zhang, S., Gao, Y., Li, X., Zhang, X., and Yang, H. (2019). Lung cancer-derived extracellular vesicles induced myotube atrophy and adipocyte lipolysis via the extracellular IL-6-mediated STAT3 pathway. Biochim Biophys Acta Mol Cell Biol Lipids 1864,

\section{1-1102. DOI: 10.1016/j.bbalip.2019.04.006}

Jung-Ting, Lee, Nathalie, Pamir, Ning-Chun, Liu, Elizabeth, A., Kirk, Michelle, M., and Averill (2014). Macrophage metalloelastase (MMP12) regulates adipose tissue expansion, insulin sensitivity, and expression of inducible nitric oxide synthase. Endocrinology.

\section{PMCID: PMC4138576}

Kettner, C., Shaw, E., White, R., and Janoff, A.J.B.J. The specificity of macrophage elastase on the insulin B-chain. 195, 369-372. PMCID: PMC1162899

Kim, T., Choi, S.E., Ha, E.S., Jung, J.G., Han, S.J., Kim, H.J., Kim, D.J., Kang, Y., and Lee, K.W. (2013). IL-6 induction of TLR-4 gene expression via STAT3 has an effect on insulin resistance in human skeletal muscle. Acta Diabetologica 50, 189-200. DOI: 10.1007/s00592-011-0259-z

Kraen, M., Frantz, S., Nihlén, U., Engström, G., Löfdahl, C.G., Wollmer, P., and Dencker, M. (2019). Matrix Metalloproteinases in COPD and atherosclerosis with emphasis on the effects of smoking. PloS one 14, e0211987-e0211987. PMCID: PMC6383934

Langlois, Stephanie, Wild, Benjamin, Cowan, Kyle, N., St-Pierre, and Marie-Eve Elastase and matrix metalloproteinase activities are associated with pulmonary vascular disease in the nitrofen rat model of congenital diaphragmatic hernia. DOI: 10.1016/j.jpedsurg.2017.01.010

Lee, J.-T., Pamir, N., Liu, N.-C., Kirk, E.A., Averill, M.M., Becker, L., Larson, I., Hagman, D.K., FosterSchubert, K.E., van Yserloo, B., et al. (2014a). Macrophage metalloelastase (MMP12) regulates adipose tissue expansion, insulin sensitivity, and expression of inducible nitric oxide synthase.

Endocrinology 155, 3409-3420. DOI: 10.1210/en.2014-1037

Lee, J.T., Pamir, N., Liu, N.C., Kirk, E.A., Averill, M.M., Becker, L., Larson, I., Hagman, D.K., Fosterschubert, K.E., and Van Yserloo, B. (2014b). Macrophage Metalloelastase (MMP12) Regulates Adipose Tissue Expansion, Insulin Sensitivity, and Expression of Inducible Nitric Oxide Synthase. Endocrinology 155, 3409-3420. PMCID: PMC4138576 
711 Lee, J.T., Pamir, N., Liu, N.C., Kirk, E.A., Averill, M.M., Becker, L., Larson, I., Hagman, D.K.,

712 Fosterschubert, K.E., and Yserloo, B.V. (2016). Macrophage metalloelastase (MMP12) regulates

713 adipose tissue expansion, insulin sensitivity, and expression of inducible nitric oxide synthase.

714 155, 3409-3420. PMCID: PMC4138576

715 Li, J., Xu, J., Yan, X., Jin, K., and Zhang, R. (2018). Targeting Interleukin-6 (IL-6) Sensitizes Anti-

716 PD-L1 Treatment in a Colorectal Cancer Preclinical Model. Medical ence Monitor International

717 Medical Journal of Experimental \& Clinical Research 24, 5501-5508. PMCID: PMC6097097

718 Liaqat, A., Rehman, K., Rasul, A., and Akash, M.S.H.J.C.R.E.G.E. (2017). Role of Interleukin-6 in

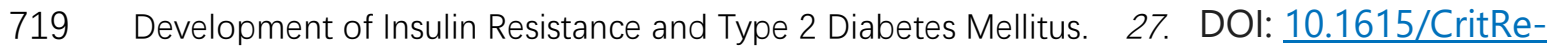

$720 \quad$ vEukaryotGeneExpr.2017019712

721 Lin, J.S., Piper, M.A., Perdue, L.A., Rutter, C.M., Webber, E.M., O'Connor, E., Smith, N., and

722 Whitlock, E.P. (2016). Screening for Colorectal Cancer: Updated Evidence Report and Systematic

723 Review for the US Preventive Services Task Force. Jama 315, 2576-2594.

724 DOI: $10.1001 /$ jama.2016.3332

725 Lobato, B., Prado, and Qian (2018). Anti-cytokines in the treatment of cancer cachexia. Annals of 726 palliative medicine. DOI: $10.21037 /$ apm.2018.07.06

727 Mahadik, and Sujata, R. (2013). Association between inflammatory cytokines and insulin resistance

728 in Indian hypertensive patients. Journal of Indian College of Cardiology 3, 163-168. DOI:

$729 \quad \underline{10.1016 / j . j i c c .2013 .06 .003}$

730 Masi, T., and Patel, B.M. (2020). Altered glucose metabolism and insulin resistance in cancer-

731 induced cachexia: a sweet poison. Pharmacological reports : PR. DOI: 10.1007/s43440-020-

$732 \underline{00179-y}$

733 Mauer, J., Chaurasia, B., Goldau, J., Vogt, M.C., Ruud, J., Nguyen, K.D., Theurich, S., Hausen, A.C.,

734 Schmitz, J., Brönneke, H.S., et al. (2014). Signaling by IL-6 promotes alternative activation of

735 macrophages to limit endotoxemia and obesity-associated resistance to insulin. Nat Immunol

736 15, 423-430. PMCID: PMC4161471 
737

738

Pettersen, K., Andersen, S., Degen, S., Tadini, V., Grosjean, J., Hatakeyama, S., Tesfahun, A.N.,

757 Moestue, S., Kim, J., Nonstad, U., et al. (2017). Cancer cachexia associates with a systemic

758 autophagy-inducing activity mimicked by cancer cell-derived IL-6 trans-signaling. Sci Rep 7,

Mauer, J., Denson, J.L., and Brüning, J.C. (2015). Versatile functions for IL-6 in metabolism and cancer. Trends in Immunology 36, 92-101. DOI: 10.1016/j.it.2014.12.008

Narsale, A.A., Carson, J.A.J.C.O.i.S., and Care, P. (2014). Role of interleukin-6 in cachexia: therapeutic implications. 8,321-327. PMCID: PMC4323347

Nicholson, T., Church, C., Tsintzas, K., Jones, R., Breen, L., Davis, E.T., Baker, D.J., and Jones, S.W. (2019). Vaspin promotes insulin sensitivity of elderly muscle and is upregulated in obesity. J

Endocrinol. DOI: 10.1530/JOE-18-0528

Nikiteas, N.I, Tzanakis, N., Gazouli, M., Rallis, G., Danilidis, K., Theodoropoulos, G., Kostakis, A., and Peros, G. (2005). Serum IL-6, TNF $\alpha$ and CRP levels in Greek colorectal cancer patients: Prognostic implications. World Journal of Gastroenterology 11, 1639-1643.

\section{PMCID: PMC4305945}

Patel, H.J., and Patel, B.M. (2017). TNF- $\alpha$ and cancer cachexia: Molecular insights and clinical implications. Life Sciences 170, 56-63. DOI: 10.1016/j.Ifs.2016.11.033

Peixoto da Silva, S., Santos, J.M.O., Costa E Silva, M.P., Gil da Costa, R.M., and Medeiros, R. (2020a). Cancer cachexia and its pathophysiology: links with sarcopenia, anorexia and asthenia. Journal of cachexia, sarcopenia and muscle 11,619-635. DOI: 10.1002/jcsm.12528

Peixoto da Silva, S., Santos, J.M.O., Costa, E.S.M.P., Gil da Costa, R.M., and Medeiros, R. (2020b). Cancer cachexia and its pathophysiology: links with sarcopenia, anorexia and asthenia. J

Cachexia Sarcopenia Muscle. PMCID: $\underline{\text { PMC7296264 }}$

2046-2046. PMCID: PMC5435723 
Puppa, M.J., White, J.P., Velázquez, K.T., Baltgalvis, K.A., Sato, S., Baynes, J.W., Carson,

761

762

763

764

765

766

767

768

769

770

771

772

773

774

775

776

Cachexia Sarcopenia Muscle 9, 358-368.

Song, W., Kir, S., Hong, S., Hu, Y., Wang, X., Binari, R., Tang, H.-W., Chung, V., Banks, A.S., Spiegelman, B., et al. (2019). Tumor-Derived Ligands Trigger Tumor Growth and Host Wasting via Differential MEK Activation. Developmental Cell 48, 277-286.e276. PMCID: PMC6368352

Suzuki, K., Meguro, K., Nakagomi, D., and Nakajima, H. (2017). Roles of alternatively activated M2 macrophages in allergic contact dermatitis. Allergology international : official journal of the Japanese Society of Allergology 66, 392-397. DOI: 10.1016/j.alit.2017.02.015

Takayama, K. (2019). [Overview of Cancer-Associated Cachexia]. Gan to kagaku ryoho Cancer \& chemotherapy 46, 1814-1817. PMID: 31879394

784 Tisdale, and Michael, J. (2002). Cachexia in cancer patients. Nature Reviews Cancer 2, 862-

785871.1441 Accesses

36 
786

787

788

789

790

791

792

793

794

795

796

797

798

799

800

801

802

803

804

805

806

807

808

809

810

811

Utsumi, K., Takai, Y., Tada, T., Ohzeki, S., and Hamaoka, T.J.J.o.I. (1990). Enhanced production of IL-6 in tumor-bearing mice and determination of cells responsible for its augmented production.

145, 397-403. PMID: 1972720:

van der Werf, A., van Bokhorst, Q.N.E., de van der Schueren, M.A.E., Verheul, H.M.W., and Langius, J.A.E. (2018). Cancer Cachexia: Identification by Clinical Assessment versus International Consensus Criteria in Patients with Metastatic Colorectal Cancer. Nutrition and cancer 70, 13221329. DOI: $10.1080 / 01635581.2018 .1504092$

Wada, E., Tanihata, J., Iwamura, A., Takeda, S., Hayashi, Y.K., and Matsuda, R. (2017). Treatment with the anti-IL-6 receptor antibody attenuates muscular dystrophy via promoting skeletal muscle regeneration in dystrophin-/utrophin-deficient mice. Skelet Muscle 7, 23.

PMCID: PMC5660454

Wagner, C.J., Schultz, C., and Mall, M.A. (2016). Neutrophil elastase and matrix metalloproteinase 12 in cystic fibrosis lung disease. Molecular and cellular pediatrics 3, 25-25.

PMCID: PMC4960106

Wallenius, V., Wallenius, K., Ahrén, B., Rudling, M., Carlsten, H., Dickson, S.L., Ohlsson, C., and Jansson, J.-O. (2002). Interleukin-6-deficient mice develop mature-onset obesity. Nature

Medicine 8, 75-79. DOI: $\underline{10.1038 / \mathrm{nm} 0102-75}$

Wang, J., An, F., Cao, Y., Gao, H., Sun, M., Ma, C., Wu, H., Zhang, B., Liu, W., and Wang, J. (2019). Association of TIMP4 gene variants with steroid-induced osteonecrosis of the femoral head in the population of northern China. Peer] 7, e6270-e6270. PMCID: PMC6348097

Wang, M., Spinetti, G., Monticone, R.E., Zhang, J., Wu, J., Jiang, L., Khazan, B., Telljohann, R., and Lakatta, E.G. (2011). A local proinflammatory signalling loop facilitates adverse age-associated arterial remodeling. PLoS One 6, e16653. PMCID: $\underline{\text { PMC3035650 }}$

Wang, Q., He, Z., Huang, M., Liu, T., Wang, Y., Xu, H., Duan, H., Ma, P., Zhang, L., and Zamvil, S.S. (2018). Vascular niche IL-6 induces alternative macrophage activation in glioblastoma through HIF-2 $\alpha$. Nature Communications 9, 559. PMCID: PMC5805734 
812 Wetzl, V., Tiede, S.L., Faerber, L., Weissmann, N., Schermuly, R.T., Ghofrani, H.A., and Gall, H.J.L.

813 Plasma MMP2/TIMP4 Ratio at Follow-up Assessment Predicts Disease Progression of Idiopathic

814 Pulmonary Arterial Hypertension. DOI: 10.1007/s00408-017-0014-5

815 Yang, J., Cao, R.Y., Li, Q., and Zhu, F. (2018). Muscle Atrophy in Cancer. Advances in experimental

816 medicine and biology 1088, 329-346. DOI: $\underline{10.1007 / 978-981-13-1435-315}$

817 Yang, Q., Yan, C., Wang, X., and Gong, Z. (2019). Leptin induces muscle wasting in a zebrafish

818 kras-driven hepatocellular carcinoma (HCC) model. Disease models \& mechanisms 12,

819 dmm038240. PMCID: $\underline{\text { PMC6398506 }}$

820 Yarla, N.S., Polito, A., and Peluso, I. (2018). Effects of Olive Oil on TNF- $\alpha$ and IL-6 in Humans:

821 Implication in Obesity and Frailty. Endocrine, metabolic \& immune disorders drug targets 18,63-

822 74. DOI: $\underline{10.2174 / 1871530317666171120150329}$

823 Yuan, L., Han, J., Meng, Q., Xi, Q., Zhuang, Q., Jiang, Y., Han, Y., Zhang, B., Fang, J., and Wu, G.

824 (2015). Muscle-specific E3 ubiquitin ligases are involved in muscle atrophy of cancer cachexia: an

825 in vitro and in vivo study. Oncology reports 33, 2261-2268. DOI: $\underline{10.3892 / o r .2015 .3845}$

826 Zhang, Y., Wang, S., Li, Y., Xiao, Z., Hu, Z., and Zhang, J. (2008). Sophocarpine and matrine inhibit 827 the production of TNF-alpha and IL-6 in murine macrophages and prevent cachexia-related 828 symptoms induced by colon26 adenocarcinoma in mice. International immunopharmacology 8 , 829 1767-1772. DOI: 10.1016/j.intimp.2008.08.008

830

831

832

833

834

835

836 
bioRxiv preprint doi: https://doi.org/10.1101/2021.01.29.428838; this version posted January 30, 2021. The copyright holder for this preprint (which was not certified by peer review) is the author/funder, who has granted bioRxiv a license to display the preprint in perpetuity. It is made available under aCC-BY 4.0 International license.

\section{Figure legends}

Figure 1

A

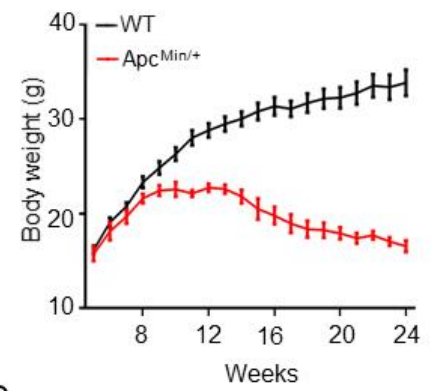

D

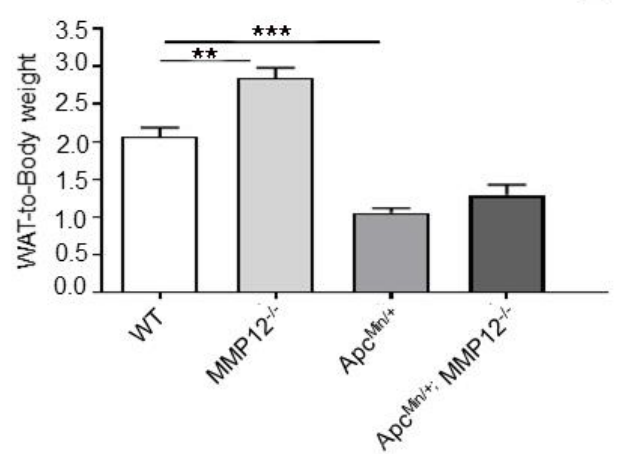

$\mathrm{F}$

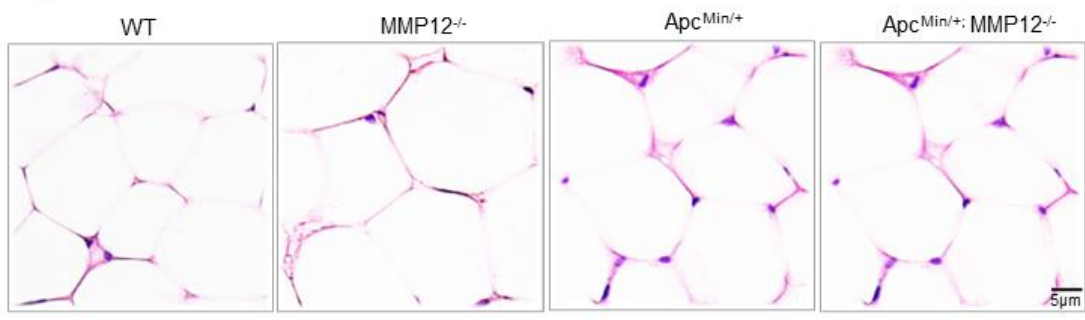

$\mathrm{H}$

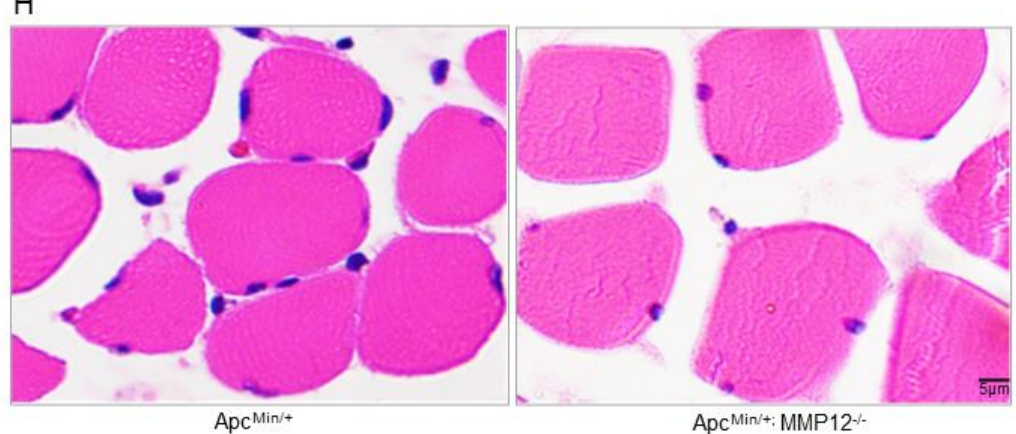

C
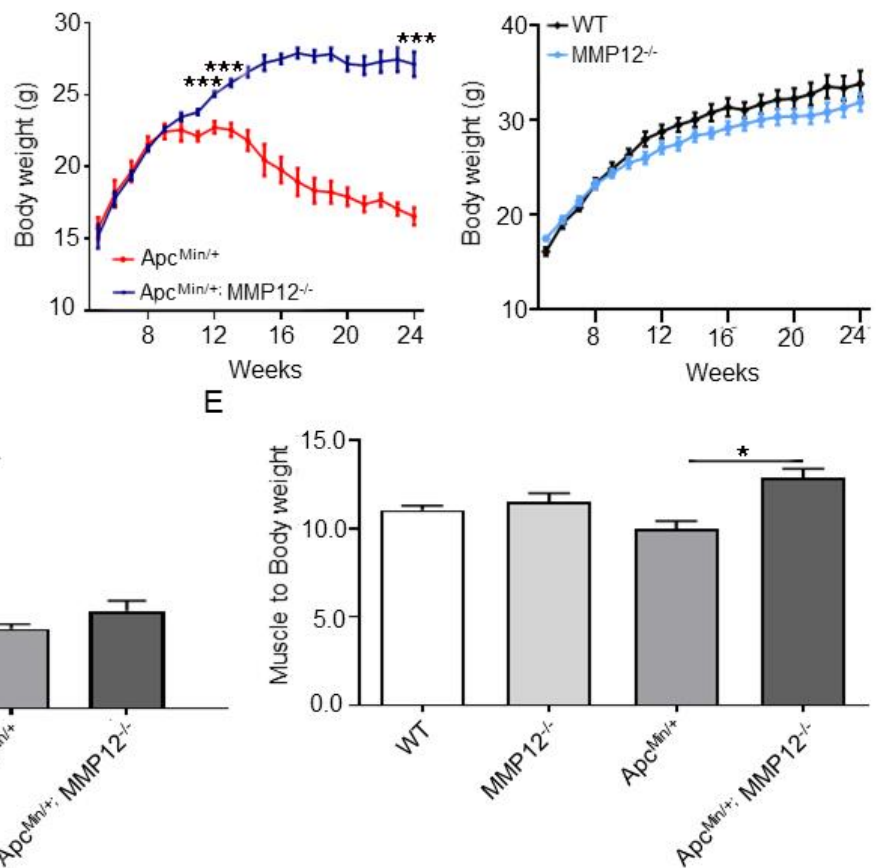

G
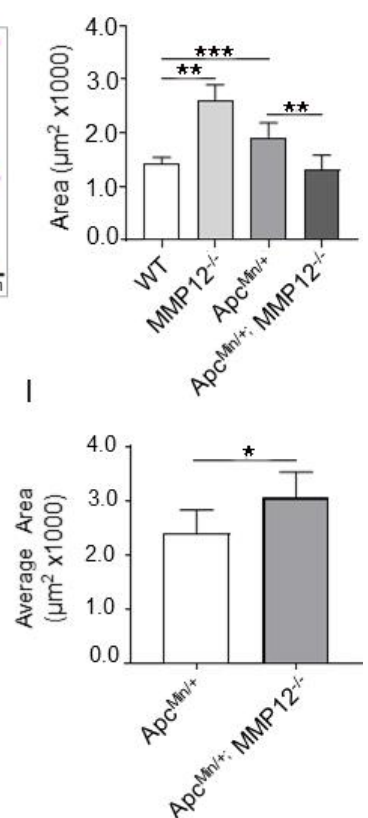


\section{Figure 1. Knockout of MMP12 in Apc $\mathrm{Ain} /+^{+}$mice prevents weight and muscle loss}

842 (A-C) Plots of the body weight of wild-type (WT), $\mathrm{Apc}^{\mathrm{Min} /+}, \mathrm{Apc}^{\mathrm{Min} /+} ; \mathrm{MMP}^{-{ }^{-/}}$and MMP12 $2^{-/}$mice from

8435 to 24 weeks $(* * * P<0.001 ; * * P<0.01 ; * P<0.05$; data are shown as the means $\pm \mathrm{SD} ; \mathrm{n}=6$ per group).

844 (D) The ratio of white adipose tissue to body weight (***P<0.001; **P<0.01, n=5). (E) The ratio of

845 skeletal muscle to body weight $(* P<0.05, \mathrm{n}=5)$. (F) Hematoxylin and eosin staining of white adipose

846 tissue in WT, Apc ${ }^{\mathrm{Min} /}$, $\mathrm{Apc}^{\mathrm{Min} /+} ; \mathrm{MMP}^{-/-}$and MMP12 $2^{-/}$mice at 24 weeks of age. Scale bars, $5 \mu \mathrm{m} .(\mathrm{G})$

847 Evaluation of the white adipose tissue across 4 groups by ImageJ software $(40 \mathrm{X})(* * * P<0.001 ; * * P<$

848 0.01, data are shown as the means $\pm \mathrm{SD} ; \mathrm{n}=5$ mice each group). (H) Hematoxylin and eosin staining of

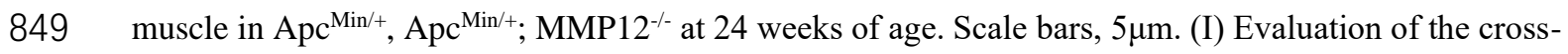

850 sectional area of the gastrocnemius from $\mathrm{Apc}^{\mathrm{Min} /+}$ mice and $\mathrm{Apc}^{\mathrm{Min} /+} ; \mathrm{MMP} 12^{-/}$mice by ImageJ software

851 (40X) $(* P<0.05$; data are shown as the means $\pm \mathrm{SD} ; \mathrm{n}=3$ mice each group). 
bioRxiv preprint doi: https://doi.org/10.1101/2021.01 29.428838; this version posted January 30,2021 . The copyright holder for this preprint (which was not certified by peer review) is the author/funder, who has granted bioRxiv a license to display the preprint in perpetuity. It is made available under aCC-BY 4.0 International license.

Figure 2
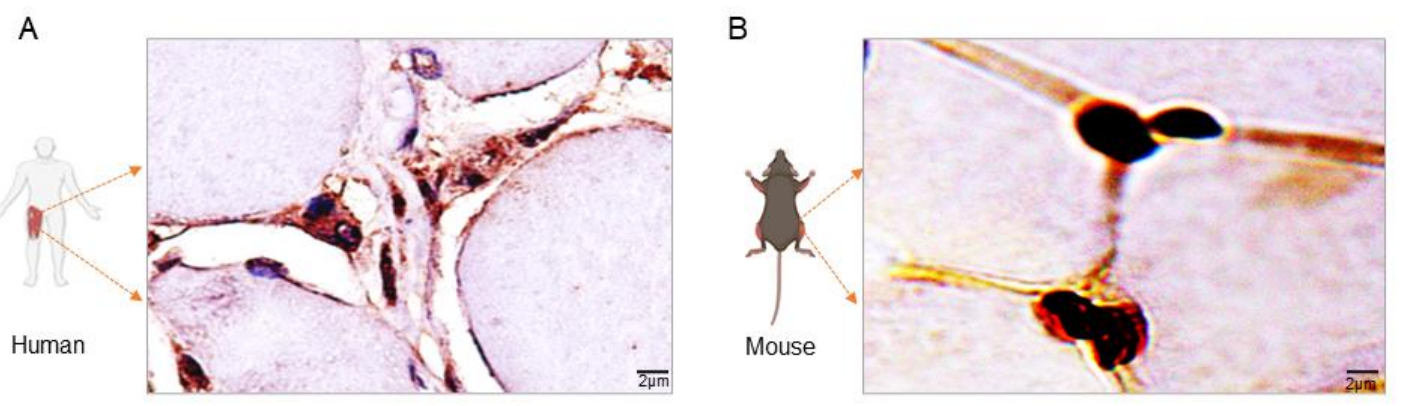

C
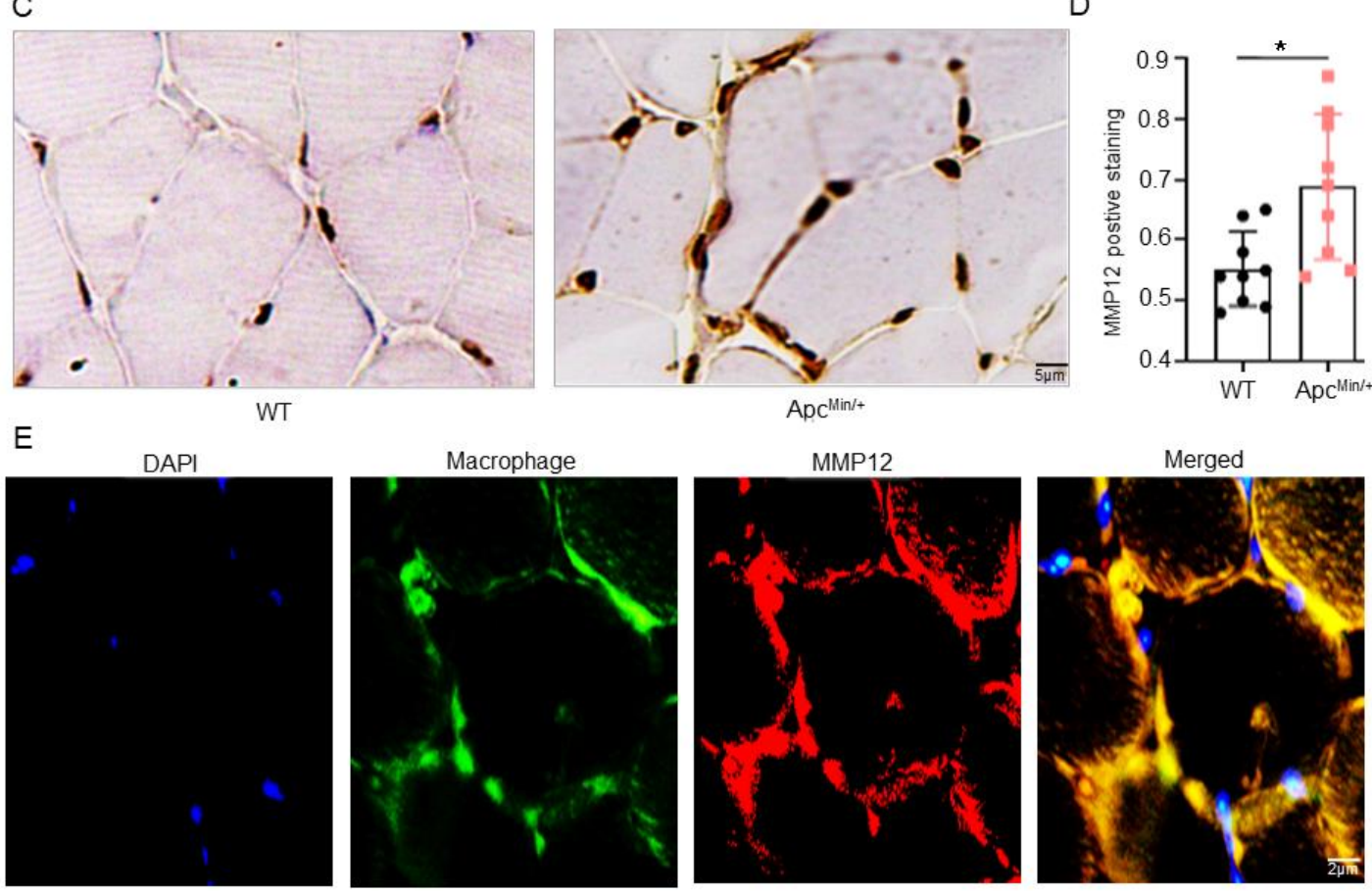

$\mathrm{F}$
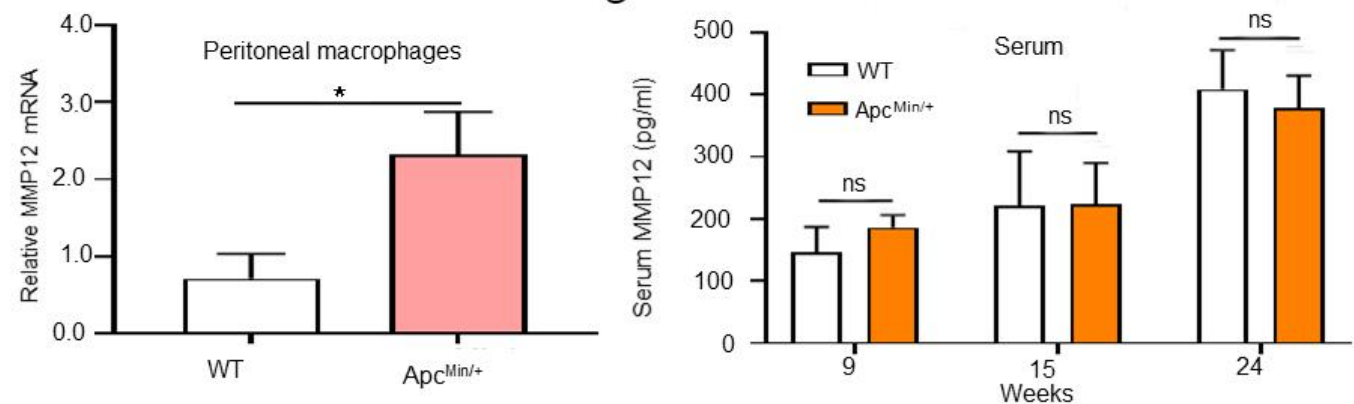


\section{Figure 2. MMP12 was upregulated in muscle tissues and macrophages of $\mathrm{Apc}^{\mathrm{Min} /+}$ mice}

857 (A) Immunostaining of MMP12-positive in muscle of clinical individuals and WT mice. Scale bar, $2 \mu \mathrm{m}$.

858 (B) Immunostaining of MMP12-positive in muscle tissue of WT mice. Scale bar, $2 \mu \mathrm{m}$ (C) Immunostain-

859 ing of MMP12-positive in muscle (gastrocnemius) from WT mice and $\mathrm{Apc}^{\mathrm{Min} /+}$ mice at 24 weeks of age.

860 Scale bar, $5 \mu \mathrm{m}$. (D) Quantification of MM12-positive in gastrocnemius tissues was performed by ImageJ

861 software $(40 \mathrm{X})(* P<0.05$, data are shown as the means $\pm \mathrm{SD} ; \mathrm{n}=4$ per group). (E) Representative

862 images of double immunofluorescent staining of macrophages (F4/80 in green) and MMP12 (in red) in

863 WT mice are shown. The yellow areas in the merged images indicate overlapping localization of the red

864 and green signals, indicated by the white arrows. Scale bars, $2 \mu \mathrm{m}$. (F) Quantification of MMP12 mRNA

865 expression level in peritoneal macrophages isolated from WT mice and $\mathrm{Apc}^{\mathrm{Min} /+}$ mice by $\mathrm{qPCR}\left({ }^{*} \mathrm{P}<\right.$

8660.05 ; data are shown as the means $\pm \mathrm{SD} ; \mathrm{n}=3$ per group). (G) The serum MMP12 levels detected in WT

867 and $\mathrm{Apc}^{\mathrm{Min} /+}$ mice at 9-,15-, and 24 weeks by enzyme-linked immunosorbent assay $(P>0.05$; data are

868 shown as the means $\pm \mathrm{SD} ; \mathrm{n}=6$ per group). 
Figure 3

A
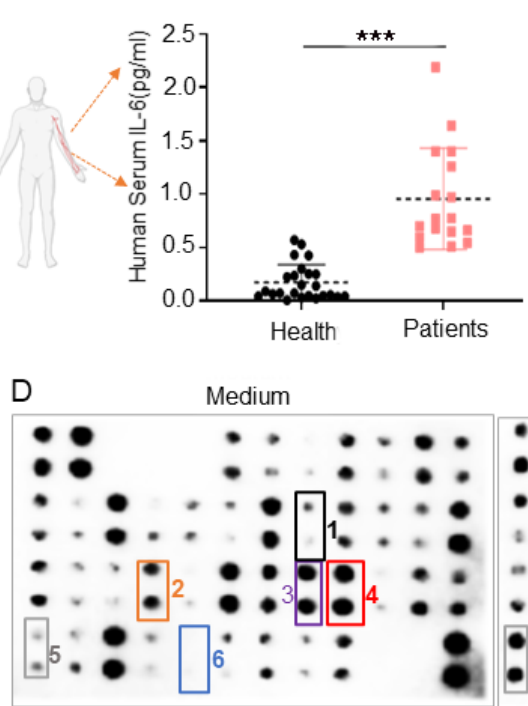

1.M-CSF

4.IL-6
B

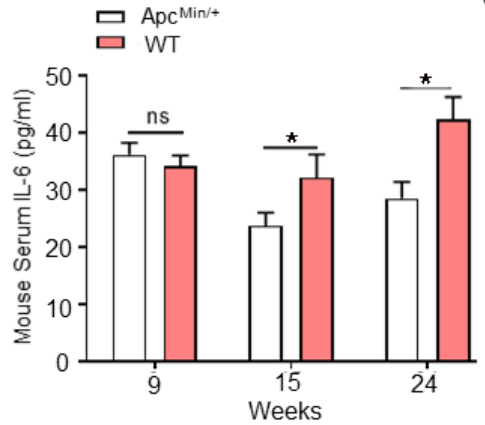

$\mathrm{C}$

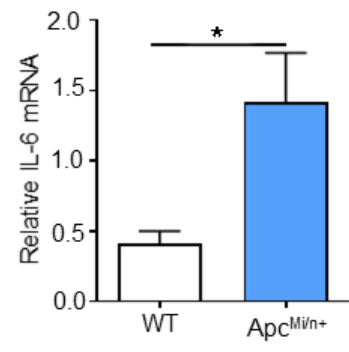

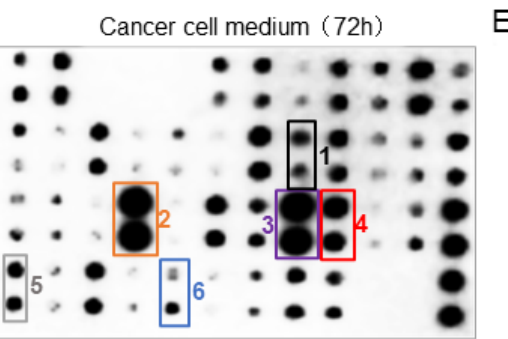

EMedium

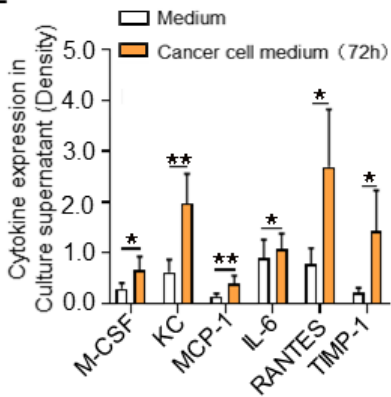

6.TMP1

\section{$870 \quad$ Figure 3. Tumor cells can secrete interleukin 6}

871 (A)Serum interleukin 6 (IL-6) levels in normal individuals and patients with colorectal cancer aged 30-

50 years detected by enzyme-linked immunosorbent assay $(* * * P<0.001$; data are shown as the means \pm

$873 \mathrm{SD} ; \mathrm{n}=26$ per group). (B) The IL-6 levels in serum in WT mice and Apc ${ }^{\mathrm{Min} /+}$ mice were detected at 9-,

874 15-, and 24 weeks old by enzyme-linked immunosorbent assay $(* P<0.05$; data are shown as the means

$875 \pm \mathrm{SD} ; \mathrm{n}=5$ per group). (C) IL-6 mRNA expression was validated in normal intestinal epithelium isolated

876 from $\mathrm{Apc}^{\mathrm{Min} /}{ }^{+}$mice versus that in intestinal tumors isolated from WT mice by $\mathrm{qPCR}(* P<0.05$; data are

877 shown as the means $\pm \mathrm{SD} ; \mathrm{n}=4$ per group). (D) Cytokine array detects inflammatory cytokines in fresh

878 untreated medium (-MC38 cells) and cultured MC-38 cells (+MC38 cells); arrows indicate the signifi-

879 cantly increased cytokines. (E) The relative quantification of the significantly upregulated cytokine to

880 positive quality control density ratio by ImageJ software. The positive quality control density was deter-

881 mined for normalization purposes $(* * P<0.01$, $* P<0.05$; data are shown as the means $\pm \mathrm{SD})$. 
bioRxiv preprint doi: $h$ ttps://doi org/10.1101/2021 0129.428838; this version posted January 30,2021 . The copyright holder for this preprint (which was not certified by peer review) is the author/funder, who has granted bioRxiv a license to display the preprint in perpetuity. It is made available under aCC-BY 4.0 International license.

Figure 4

A

Tumor cells co-culture with Macrophages

Macrophages

RAW264.7

F

IL-6 Treatment Macrophages Protocol

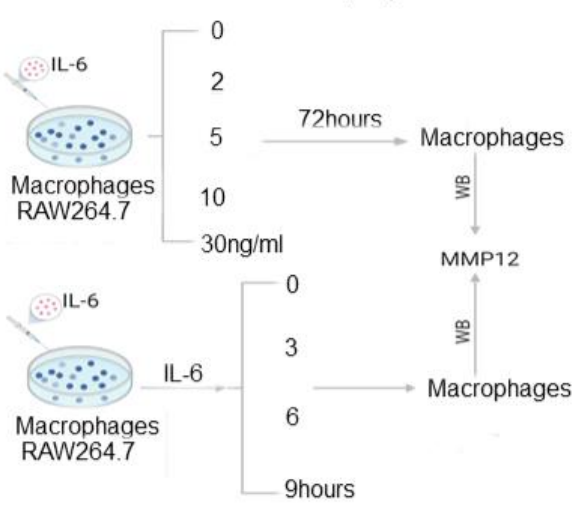

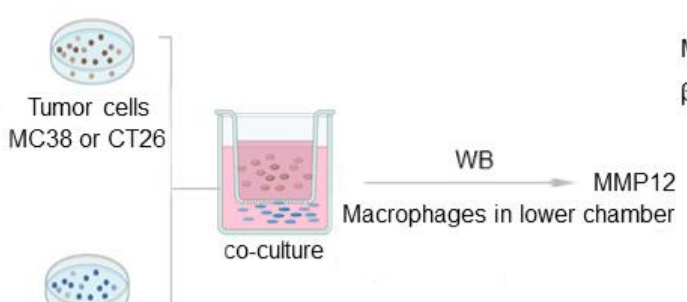

B

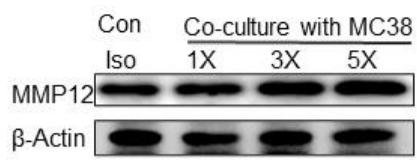

D

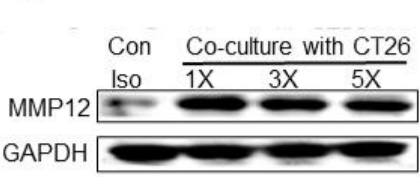

G
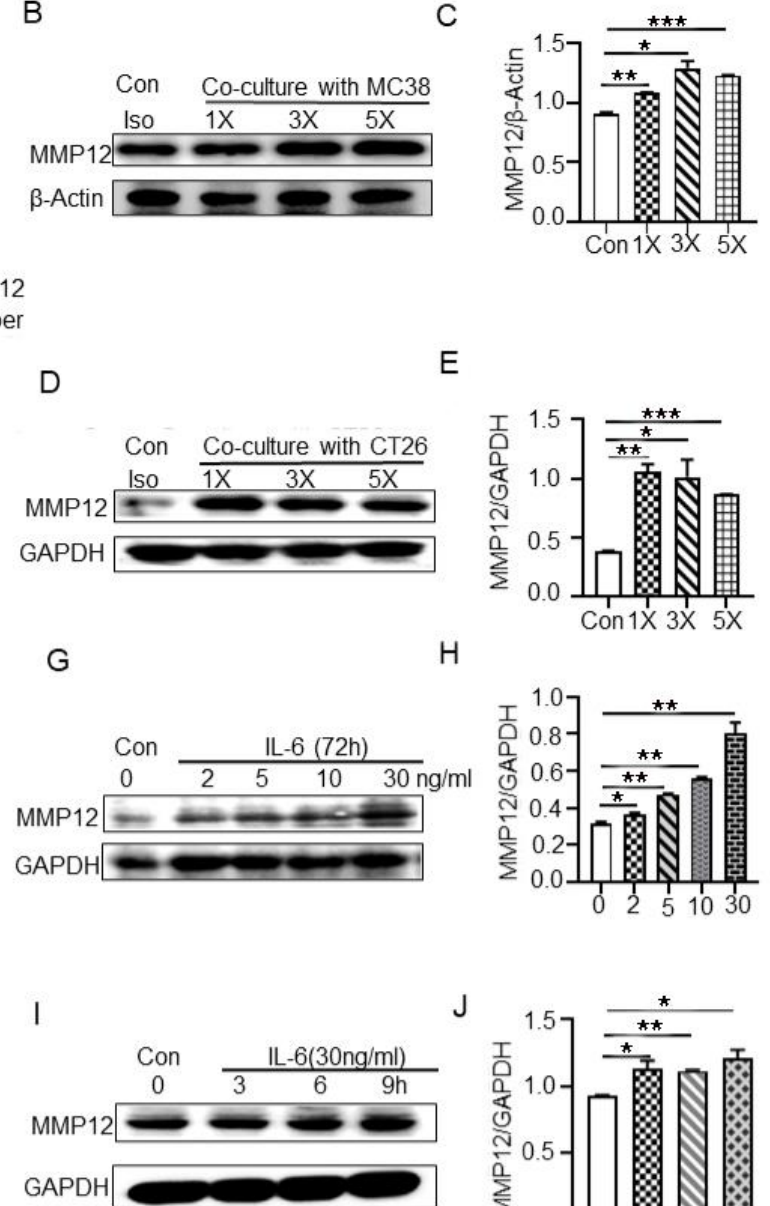

$\mathrm{H}$
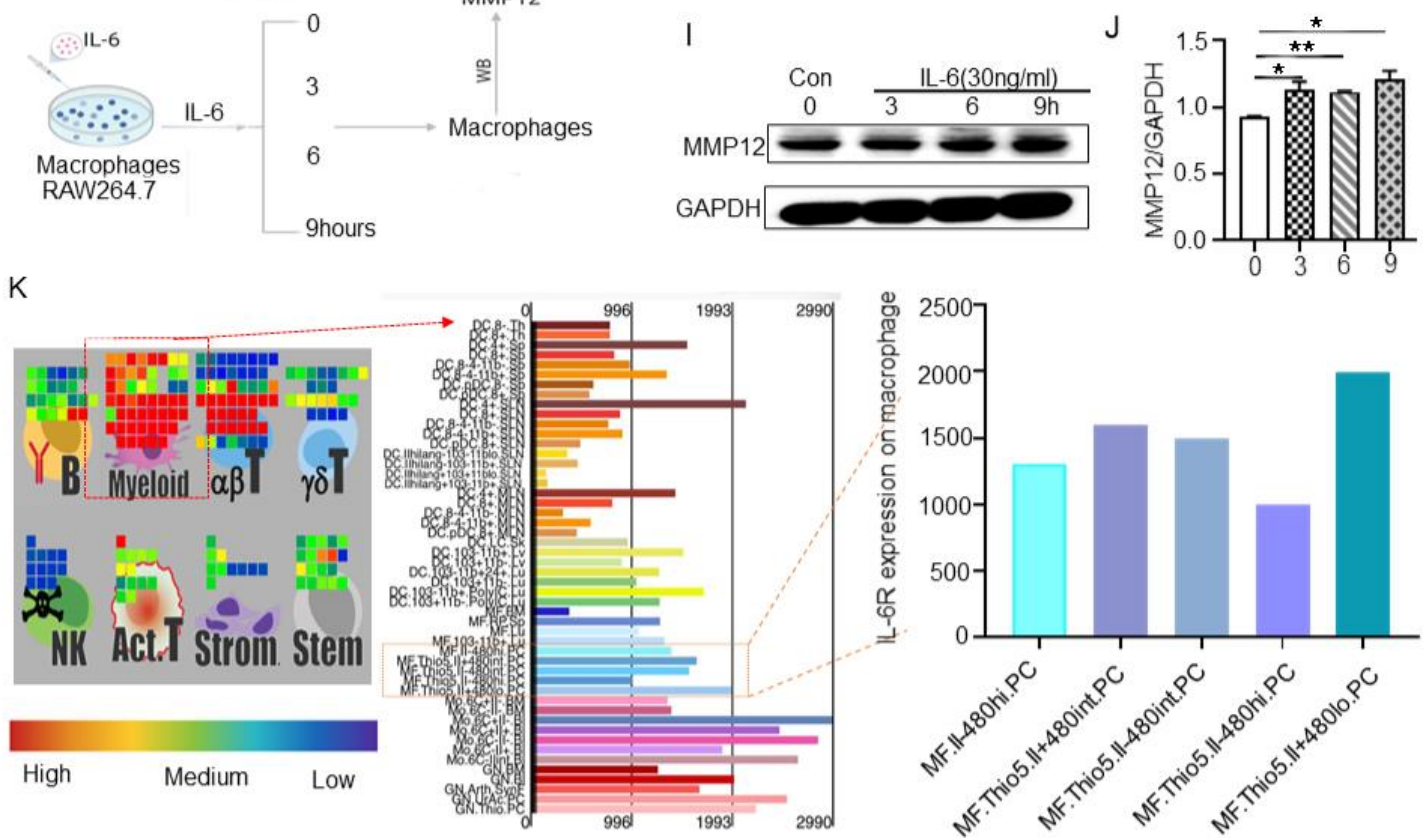


\section{Figure 4. Tumor-derived IL-6 can upregulate MMP12 in macrophages.}

887 (A)Schematic diagram of tumor cells (MC38/CT26 cell lines) coculture with macrophage cells

888 (RAW264.7 cell lines). All quantifications use image J software grayscale statistics. (B, C) Representa-

889 tive western blots showing the secreted MMP12 protein levels from RAW264.7 cell lines $\left(1-2 \times 10^{5}\right)$ cul-

890 tured alone or cocultured with MC38 cell lines (control, $\left.1 \times 10^{4}, 3 \times 10^{4}, 5 \times 10^{4}\right) . \beta$-Actin was used as the

891 internal control for normalization purposes. (D, E) Representative western blots showing the secreted

892 MMP12 protein levels from RAW264.7 cell lines $\left(1-2 \times 10^{5}\right)$ cultured alone or cocultured with CT26 cell

893 lines (control, $\left.1 \times 10^{4}, 3 \times 10^{4}, 5 \times 10^{4}\right)$. GAPDH was used as the internal control for normalization purposes.

894 (F) Schematic diagram of IL-6 treated macrophages. RAW264.7 cells incubated with fresh media were

895 served as untreated negative controls. Using western bloting to detect MMP12 in RAW 264.7 cells and

896 GAPDH was used as the internal control. (G, H) RAW264.7 cells $\left(1-2 \times 10^{5}\right)$ were seeded into 6-well

897 plates and treated with increasing doses of IL-6 (0, 2, $510,30 \mathrm{ng} / \mathrm{mL})$ for 72hours. (I, J) RAW264.7 cells

$898\left(1-2 \times 10^{5}\right)$ were treated continuously with IL-6 (30 ng/ml) for 0, 3, 6, and 9hours. (K) Immune gene data

899 proved that IL-6 receptor is expressed on myeloid cells and the red box represents F480 ${ }^{+}$macrophages.

900 The colored bars refer to the expression level of IL-6 receptors on macrophages. Red represents high

901 expression of IL-6 receptors, and green represents low expression of IL-6 receptors. 
bioRxiv preprint doi: https://doi.org/10.1101/2021.01.29.428838; this version posted January 30, 2021. The copyright holder for this preprint (which was not certified by peer review) is the author/funder, who has granted bioRxiv a license to display the preprint in perpetuity. It is made available under aCC-BY 4.0 International license.

Figure 5

A

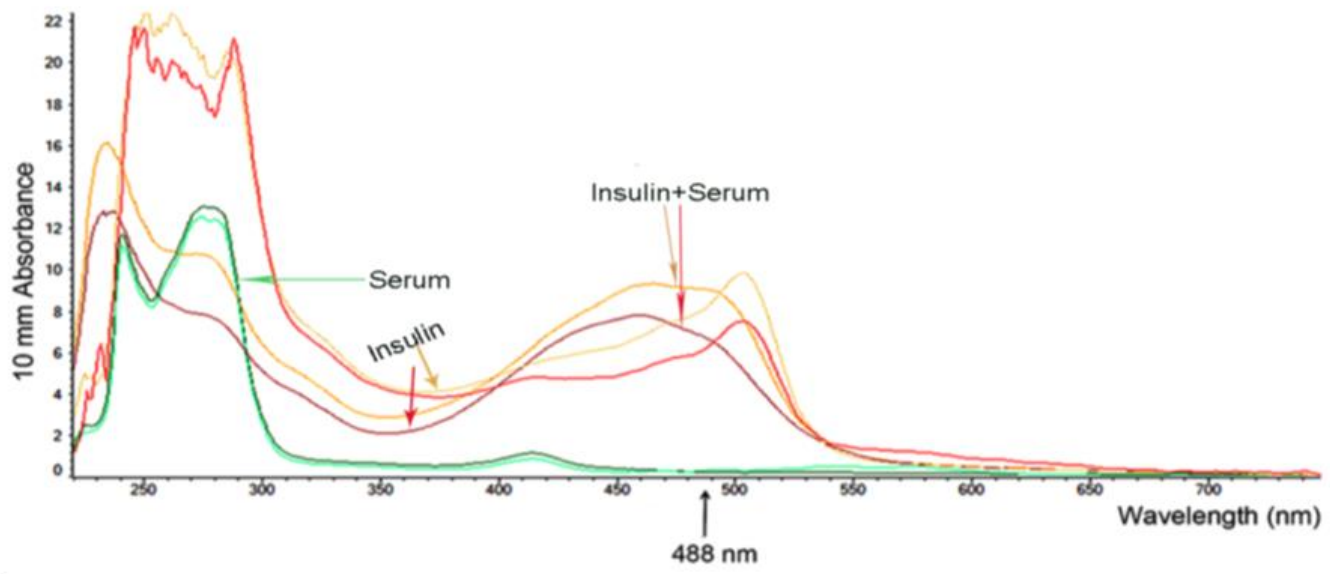

B

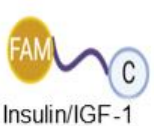

$\because 000$ +MMP12 Insulin/IGF-1
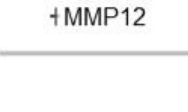

C

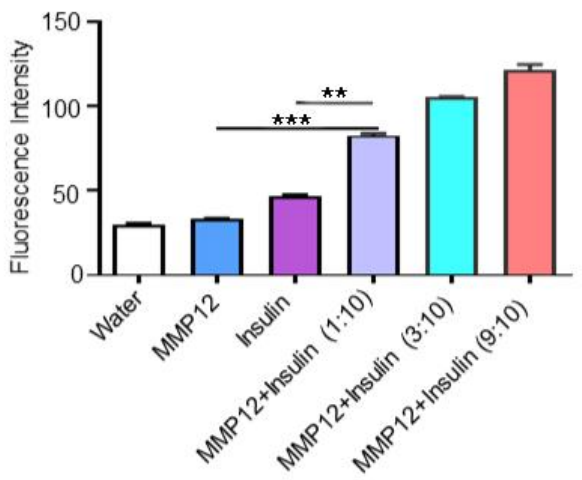

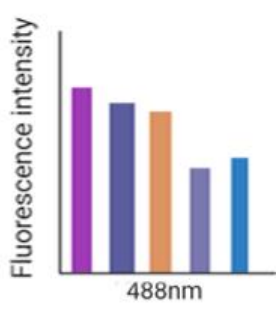

Degraded Insulin/IGF-1
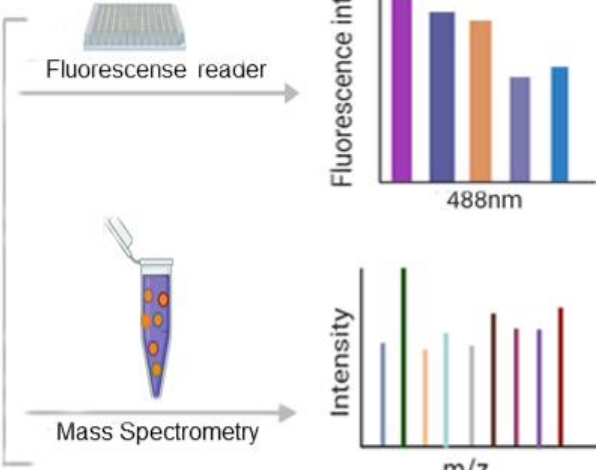

$\mathrm{m} / \mathrm{z}$

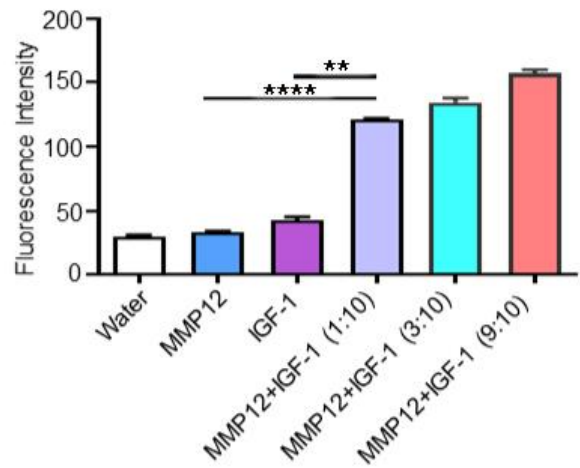




\section{Figure 5. MMP12 can degrade insulin and insulin-like growth factor-1}

907 (A) Representative picture of the peak shift after the insulin polypeptide interacts with serum. (A) The

synthetic insulin (or insulin-like growth factor-1) peptide was labeled with FAM and DABCLY as shown;

909 if the insulin (or insulin-like growth factor-1) peptide was degraded, the FAM signal was detected. This

910 is based on fluorescence resonance energy transfer (FRET); Detection of characteristic peaks of insulin

911 alone and the mixture of insulin (or insulin-like growth factor-1) and MMP12 by ionization mass spec-

912 trometry. (C)The coexistence of MMP12 and insulin (or insulin-like growth factor-1) peptide led to a

913 fluorescence signal and appeared dose-dependent $(* * * P<0.001$, $* * P<0.01$; data are shown as the means

$914 \pm \mathrm{SD})$

Figure 6

A

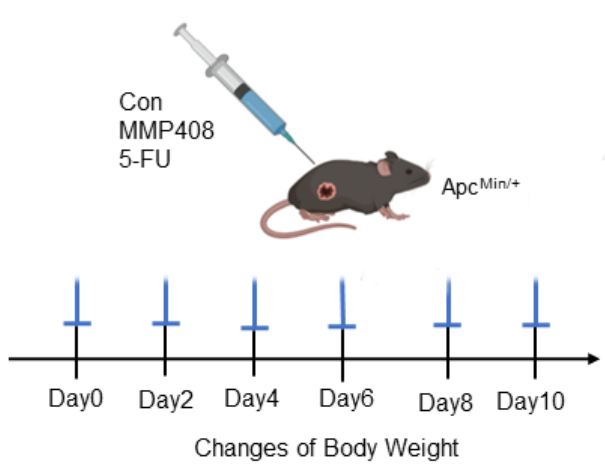

B

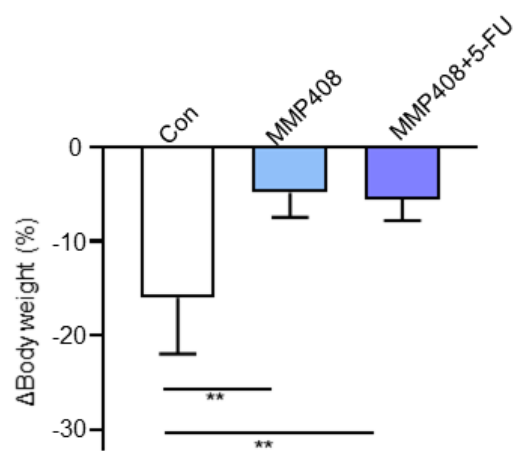

\section{Figure 6. Inhibiting MMP12 in Apc ${ }^{\mathrm{Min} /+}$ mice reduces weight loss}

917 (A)Schematic diagram of the administration process of 17 -week $\mathrm{Apc}^{\mathrm{Min} / \mathrm{+}}$ mice. The drug was given every

918 two days (MMP408-5mg/kg, 5-FU-30mg/kg). The saline group was used as a control. (B) Percentage of

919 weight gain compared to the basal weight after administration of drugs in $\mathrm{Apc}^{\mathrm{Min} /+}$ mice $(* * P<0.01$, data are shown as the means $\pm \mathrm{SD} ; \mathrm{n}=5$ per group). 
bioRxiv preprint doi: https://doi org/101101/2021.0129,428838; this version posted January 30, 2021. The copyright holder for this preprint (which was not certified by peer review) is the author/funder, who has granted bioRxiv a license to display the preprint in perpetuity. It is made available under aCC-BY 4.0 International license.

Figure 7

Tumor-derived IL-6 to MMP12 in Muscle macrophage Metastasis

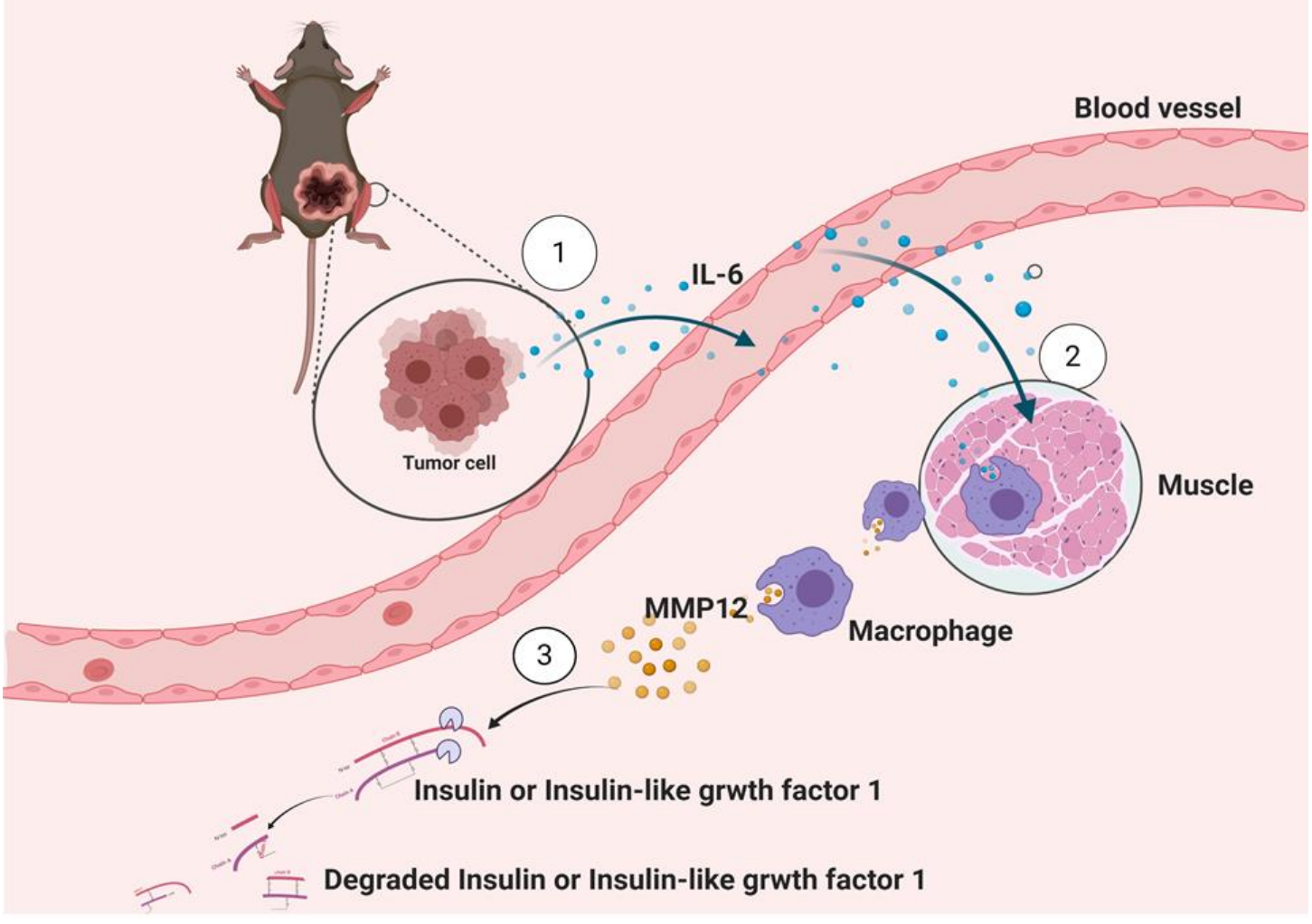

923 Figure 7. The role of MMP12 in the crosstalk between tumor and muscular macrophage in 


\section{Supplementary data}

Figure S1

A

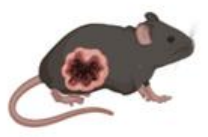

$\mathrm{Apc}^{\mathrm{Min} /+}$

\section{$\mathrm{X}$}

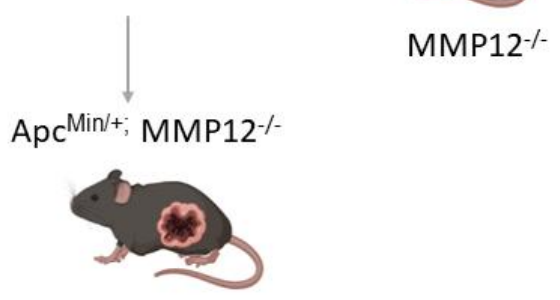

B

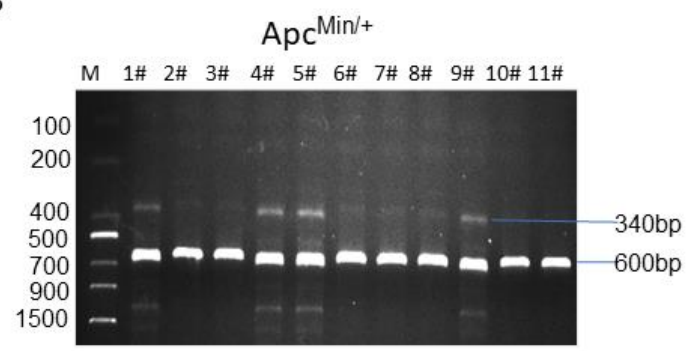

$\mathrm{MMP} 12^{-1-}$

M 1\# 2\# 3\# 4\# 5\# 6\# 7\# 8\# 9\# 10\#11\#

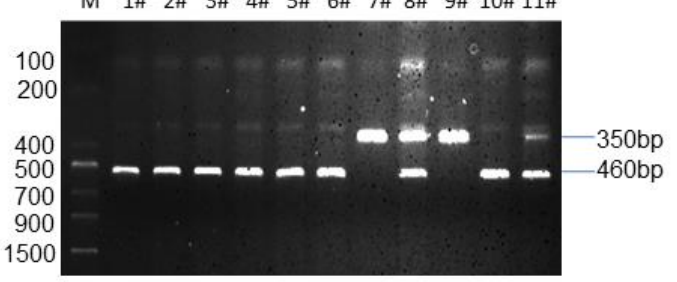

A. Schematic of the crossbreeding of $\mathrm{Apc}^{\mathrm{Min} /+}$ mice with $\mathrm{MMP}^{2-/-}$ mice to obtain $\mathrm{Apc}^{\mathrm{Min} /+}$;

938 MMP12-- mice. B. The APC gene mutant PCR product size was $340 \mathrm{bp}$, and the PCR product size of

939 wild-type (WT) mice was $600 \mathrm{bp}$. The MMP12 knockout (mutation) PCR product size was $460 \mathrm{bp}$, and

940 the WT (WT) PCR product size was $350 \mathrm{bp}$. In detail, Apc ${ }^{\mathrm{Min} /+}: 1 \#$, 4\#, 5\#, 9\#; MMP12 $2^{--}: 1 \#, 2 \#, 3 \#, 4 \#$,

$9415 \#, 6 \#, 10 \#, 11 \# ; \mathrm{Apc}^{\mathrm{Min} /+} ; \mathrm{MMP12} 2^{-/}: 1 \#, 4 \#, 5 \#$. 
Figure S2

A

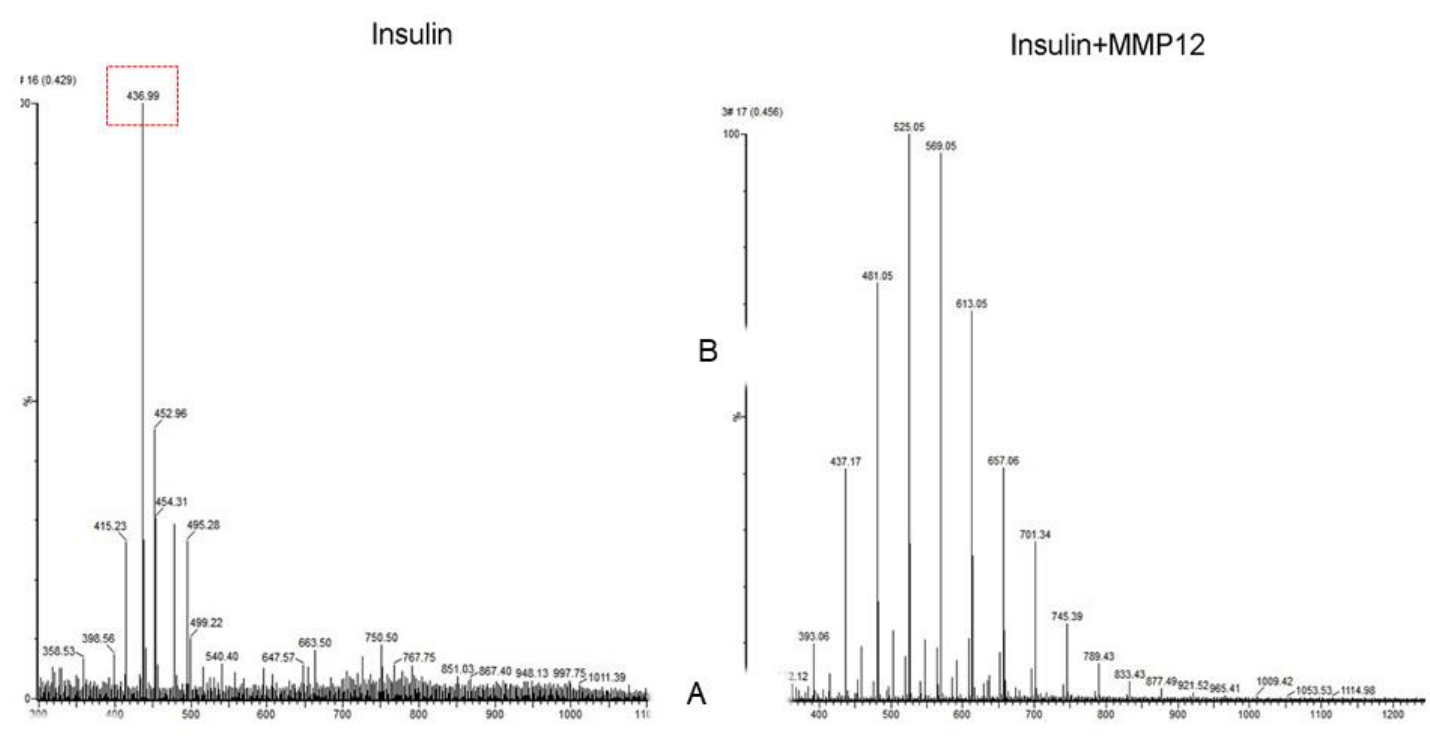

B

IGF-1

IGF-1+MMP12
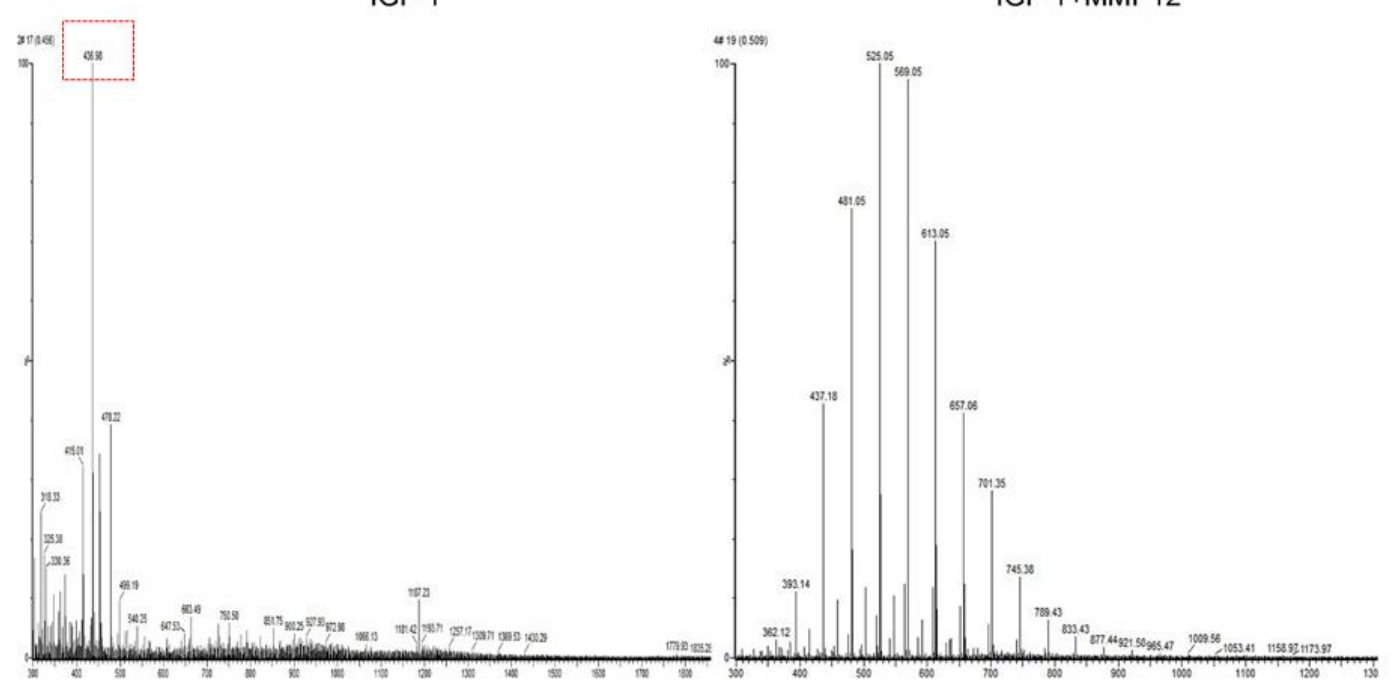

945 Figure S2 Ionization mass spectrometry analysis report: the characteristic peak of insu-

\section{$946 \quad$ lin (insulin-like growth factor 1) disappears after incubating with MMP12.}

947 (A) The characteristic peak of insulin $(\mathrm{m} / \mathrm{z}=436.99)$ and disappeared after incubation with MMP12.

948 (B) The characteristic peak of insulin-like growth factor $1(\mathrm{~m} / \mathrm{z}=436.98)$ disappeared after incubation

949 with MMP12. 
bioRxiv preprint doi: https://doi org/10.1101/2021.01 29.428838; this version posted January 30,2021 . The copyright holder for this preprint (which was not certified by peer review) is the author/funder, who has granted bioRxiv a license to display the preprint in perpetuity. It is made available under aCC-BY 4.0 International license.

Figure S3

A

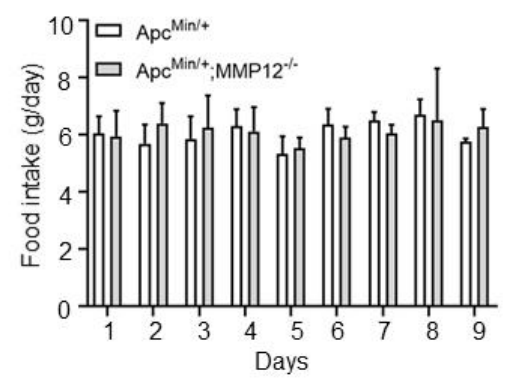

C

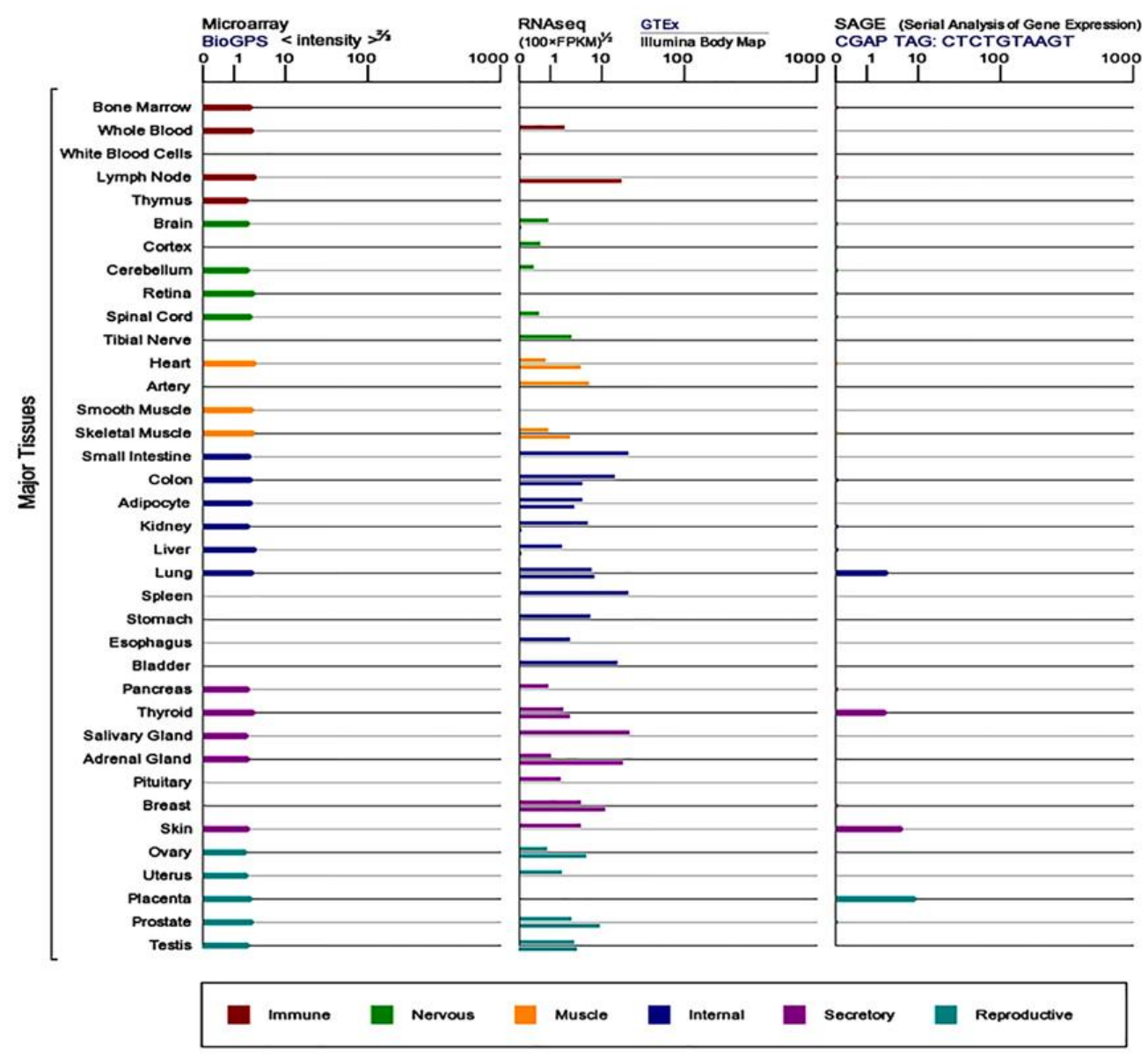

B

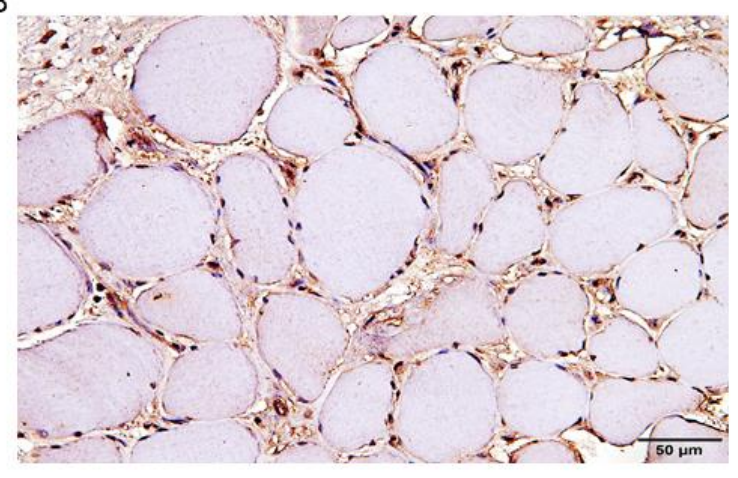

SAGE (Serial Analysis of Gene Expression) 


\section{Figure S3 Knockout of MMP12 does not affect the food intake of Apc ${ }^{\mathrm{Min} /+}$ mice and}

\section{MMP12 is expressed in bone marrow, muscle, liver and adipose tissue.}

955 (A)There was no difference in food intake between $\mathrm{Apc}^{\mathrm{Min} /+}$ mice and $\mathrm{Apc}^{\mathrm{Min} /+} ; \mathrm{MMP}^{-2_{-}}$mice. The

956 weight of food consumed after fasting for $8 \mathrm{~h}$ was measured every day starting on 17 -week. Each group

957 of mice had three cages, and each cage had 5 mice. (B) Immunostaining of MMP12-positive in muscle

958 (gastrocnemius) from the clinical individual. Scale bar, 50 4 m. (C) A mRNA analysis of the data got

959 from The Cancer Genome Atlas (TCGA) for GTEx, Illumina, BioGPS and SAGE of MMP12 gene in normal human tissues. 
bioRxiv preprint doi: https://doi.org/10.1101/2021.0129.428838; this version posted January 30, 2021. The copyright holder for this preprint (which was not certified by peer review) is the author/funder, who has granted bioRxiv a license to display the preprint in perpetuity. It is made available under aCC-BY 4.0 International license.

Figure S4

A

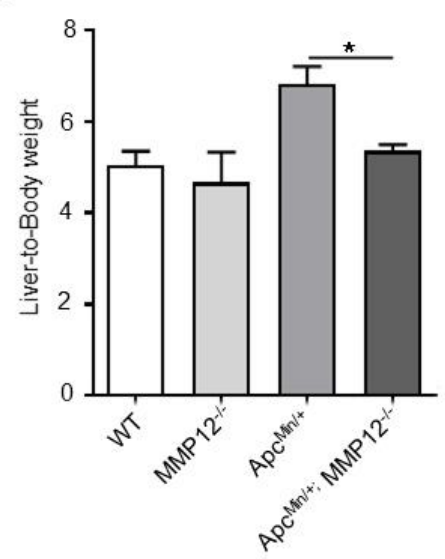

D

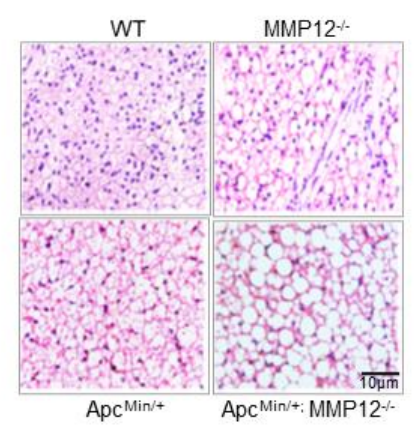

B

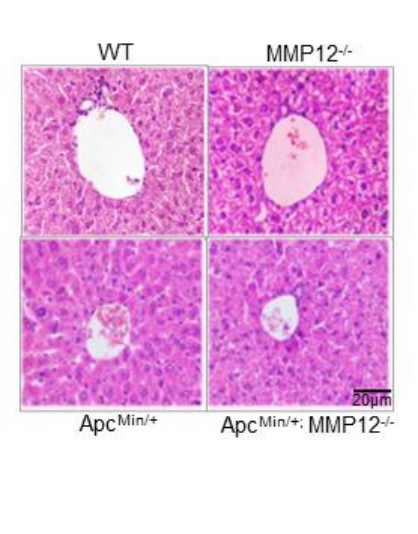

$E$

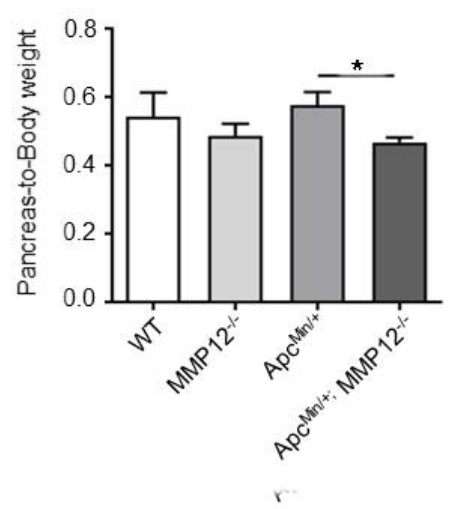

C

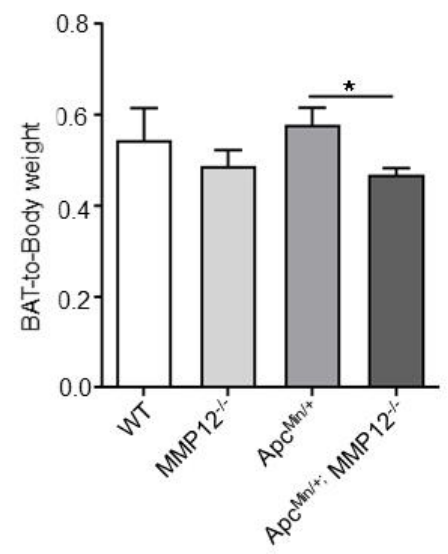

$\mathrm{F}$

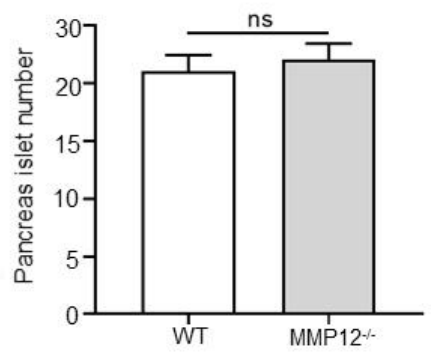

G

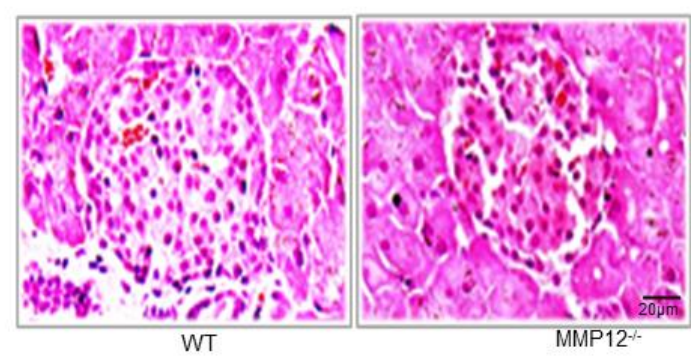

$\mathrm{H}$

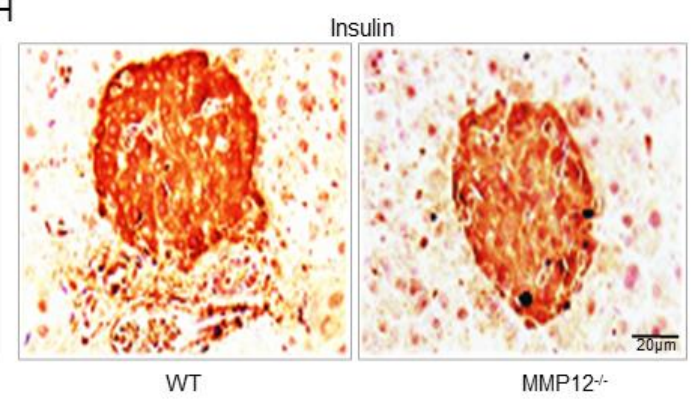




\section{Figure S4 The effect of knocking out MMP12 in Apc $\mathrm{Ain}^{\mathrm{Mi}+}$ mice on liver, brown adi-}

\section{5 pose tissue and pancreatic islets.}

966 (A)The liver-to-body weight ratio. (B) Hematoxylin and eosin staining (H\&E) of the liver at 24 weeks.

967 Scale bar, $20 \mu \mathrm{m}(* P<0.05$ data are shown as means $\pm \mathrm{SD} ; \mathrm{n}=6$ per group). (C)Brown adipose tissue-

968 to-body weight ratio was higher in $\mathrm{Apc}^{\mathrm{Min} /+} ; \mathrm{MMP12}{ }^{-/-}$mice than in $\mathrm{Apc}^{\mathrm{Min} /+}$ mice $\left({ }^{*} P<0.05\right.$ data are

969 shown as means $\pm S D ; n=6$ per group). (D) The results of $H \& E$ indicate that white fat increased

970 in brown fat in MMP12 knockout mice. Scale bar, 10 $\mu \mathrm{m}$. (E) The pancreas-to-body weight ratio

$971 \quad(* P<0.05$ data are shown as means $\pm \mathrm{SD} ; \mathrm{n}=6$ per group). (F) The number of islets between $\mathrm{WT}$ and

972 MMP12-- mice $(P>0.05$; data are shown as the means $\pm \mathrm{SD} ; \mathrm{n}=6$ per group). (G) The staining results

973 of H\&E for pancreas WT and MMP12 $2^{--}$mice at 24 weeks. Scale bar,20 $\mu \mathrm{m}$. (H)Immunostaining of 
974 insulin-positive in WT mice and in MMP12-/- pancreases at 24 weeks of age. Scale bar, $20 \mu \mathrm{m}$.

Figure S5

A

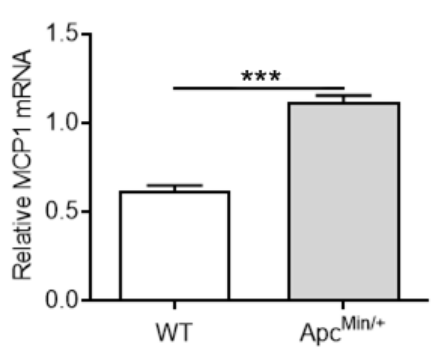

B

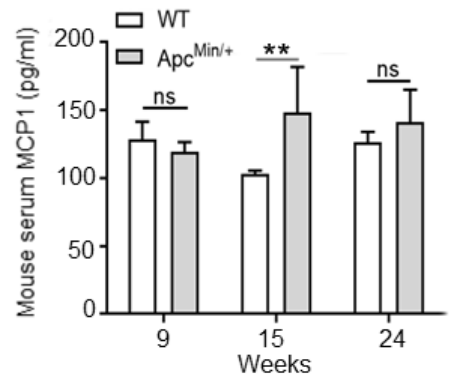

C

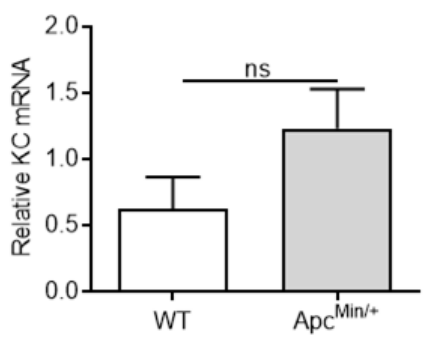

D

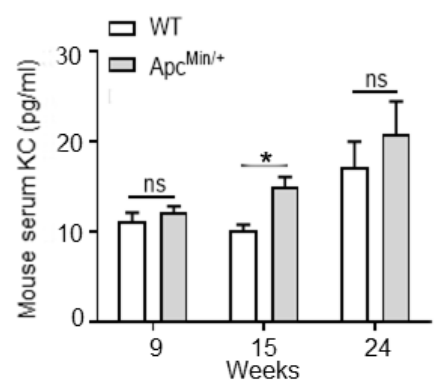

E

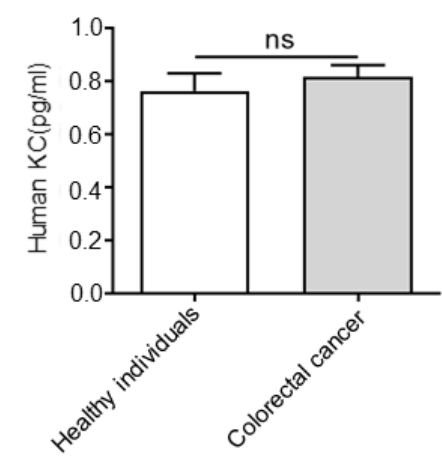


Figure S6

A

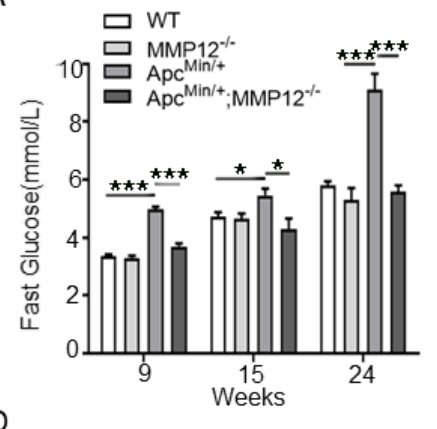

D

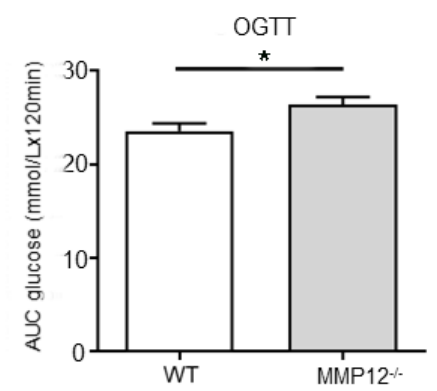

G

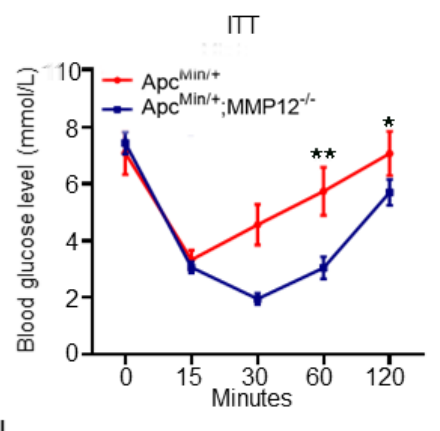

$J$

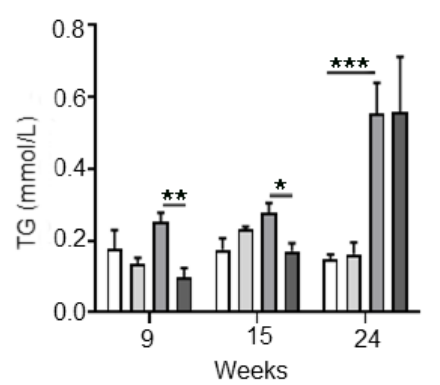

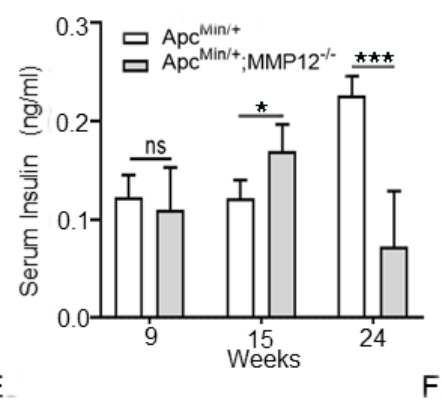

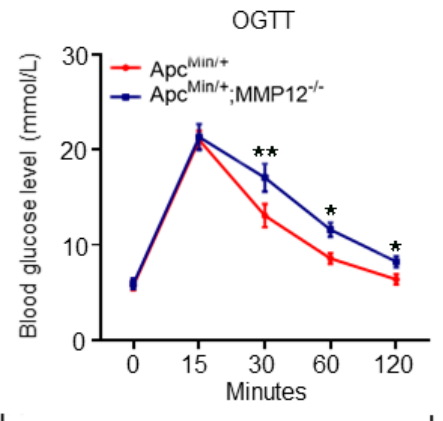

$\mathrm{H}$
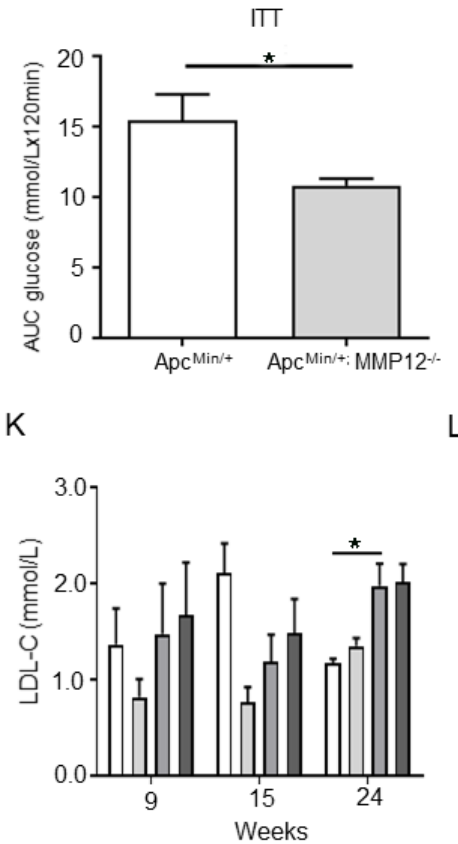

C
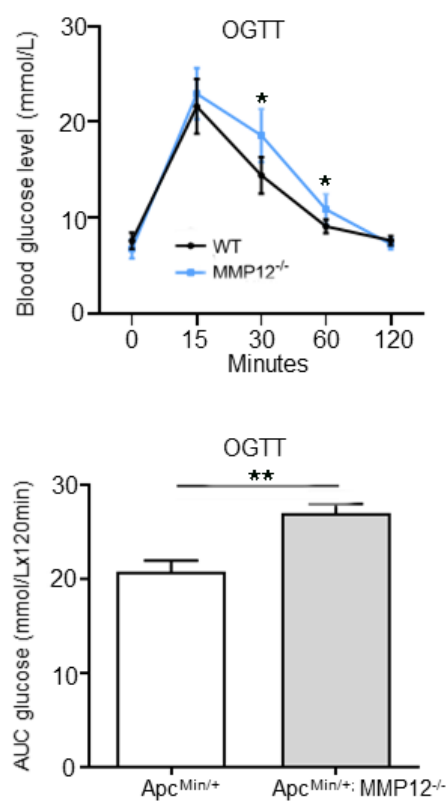
Figure S6 Knockout MMP12 affects glycolipid metabolism in Apc $\mathrm{Ain} /+^{+}$mice.

989 (A)Fasting plasma glucose levels at 9, 15 and 24 weeks of age in WT mice, MMP12-/- mice, Apc ${ }^{\mathrm{Min} /+}$

990 mice and $\mathrm{Apc}^{\mathrm{Min} /+} ; \mathrm{MMP} 12^{-/-}$mice $(* * * P<0.001, * P<0.05 ;$ data are shown as the means $\pm \mathrm{SD} ; \mathrm{n}=4$

991 per group). (B) Enzyme-linked immunosorbent assay was used to detect fasting serum insulin levels in

$992 \mathrm{Apc}^{\mathrm{Min} /+}$ and $\mathrm{Apc} \mathrm{Min} /+^{\mathrm{N}} ; \mathrm{MMP12} 2^{-/-}$mice at approximately 9,15 and 24 weeks of age $(* * * P<0.001 ; * P<$

9930.05 ; data are shown as the means $\pm \mathrm{SD} ; \mathrm{n}=4$ per group). (C) Oral Glucose Tolerance Test (OGTT):

$994 \mathrm{WT}, \mathrm{MMP} 12^{-/-}$mice were fasted for $4 \mathrm{~h}$ and then administered glucose $(75 \mathrm{IU} / \mathrm{kg}),(* P<0.05$; data are

995 shown as the means $\pm \mathrm{SD} ; \mathrm{n}=6$ per group). (D) Area under the curves for the OGTT-AUG, which was

996 increased in MMP12 ${ }^{-/-}$mice compared with that in WT mice $\left({ }^{*} P<0.05\right.$ data are shown as means \pm SD;

$997 \mathrm{n}=6$ per group). (E) OGTT: Apc $\mathrm{Min} /+$ and $\mathrm{Apc}^{\mathrm{Min} /+} ; \mathrm{MMP}^{-2^{--}}$mice were fasted for $4 \mathrm{~h}$ and then admin-

998 istered glucose $(75 \mathrm{IU} / \mathrm{kg}),(* * P<0.01, * P<0.05$ data are shown as means $\pm \mathrm{SD} ; \mathrm{n}=6$ per group). (F)

999 Areas under the curves for the OGTT-AUG, which was significantly increased in Apc ${ }^{\mathrm{Min} /+} ; \mathrm{MMP}^{-2^{--}}$

1000 mice compared with that in $\mathrm{Apc}^{\mathrm{Min} /+}$ mice $(* * P<0.01$, data are shown as means $\pm \mathrm{SD} ; \mathrm{n}=6$ per group)

1001 (G) Insulin tolerance test (ITT): mice were fasted for 4 hours; $\mathrm{Apc}^{\mathrm{Min} /+}$ and $\mathrm{Apc}^{\mathrm{Min} /+}$; MMP12 ${ }^{-/-}$mice

1002 then received an ip injection of insulin $(* * P<0.01$, data are shown as means $\pm \mathrm{SD} ; \mathrm{n}=6$ per group).

1003 (H) Areas under the curves for the ITT-AUG, which was significantly decreased in Apc ${ }^{\mathrm{Min} /+} ; \mathrm{MMP}^{2 /-}$

1004 mice compared with that in $\mathrm{Apc}^{\mathrm{Min} /+}$ mice $(* P<0.05$ data are shown as means $\pm \mathrm{SD} ; \mathrm{n}=6$ per group $)$.

1005 (I-L) Quantitative determination of serum total cholesterol (TC), total triglyceride (TG), low density

1006 lipoprotein-cholesterol (LDL-C), high density lipoprotein-cholesterol (HDL-C) in WT mice, MMP12 ${ }^{-/-}$

1007 mice, $\mathrm{Apc}^{\mathrm{Min} /+}$ mice and $\mathrm{Apc}^{\mathrm{Min} /+} ; \mathrm{MMP}^{-/-}$mice by kits at 9, 15 and 24 weeks of age $(* * * P<0.001$, 
$* * P<0.01, * P<0.05$ data are shown as means $\pm \mathrm{SD} ; \mathrm{n}=7$ per group).

Figure S7

Cytokine Assay

\begin{tabular}{|c|c|c|c|c|}
\hline $\begin{array}{c}\text { BLC } \\
\text { (CXCL13) }\end{array}$ & $\begin{array}{c}\text { CD30 Ligand } \\
\text { (TNFSF8) }\end{array}$ & $\begin{array}{c}\text { Eotaxin-1 } \\
\text { (CCL11) }\end{array}$ & $\begin{array}{c}\text { Eotaxin-2 } \\
\text { (MPIF-2/CCL24) }\end{array}$ & $\begin{array}{c}\text { Fas Ligand } \\
\text { (TNFSF6) }\end{array}$ \\
\hline $\begin{array}{c}\text { Fractalkine } \\
\text { (CX3CL1) }\end{array}$ & GCSF & GM-CSF & IFN-gamma & $\begin{array}{c}\text { IL-1 alpha } \\
\text { (IL-1 F1) }\end{array}$ \\
\hline $\begin{array}{c}\text { IL-1 beta } \\
\text { (IL-1 F2) }\end{array}$ & IL-2 & IL-3 & IL-4 & IL-6 \\
\hline IL-9 & IL-10 & IL-12 p40/p70 & IL-12 p70 & IL-13 \\
\hline IL-17A & $\begin{array}{c}\text { I-TAC } \\
\text { (CXCL11) }\end{array}$ & $\begin{array}{c}\text { KC } \\
\text { (CXCL1) }\end{array}$ & Leptin & LIX \\
\hline $\begin{array}{c}\text { Lymphotactin } \\
\text { (XCL1) }\end{array}$ & $\begin{array}{c}\text { MCP-1 } \\
\text { (CCL2) }\end{array}$ & M-CSF & $\begin{array}{c}\text { MIG } \\
\text { (CXCL9) }\end{array}$ & $\begin{array}{c}\text { MIP-1 alpha } \\
\text { (CCL3) }\end{array}$ \\
\hline MIP-1 gamma & $\begin{array}{c}\text { RANTES } \\
\text { (CCL5) }\end{array}$ & $\begin{array}{c}\text { SDF-1 alpha } \\
\text { (CXCL12 alpha) }\end{array}$ & $\begin{array}{c}\text { I-309 } \\
\text { (TCA-3/CCL1) }\end{array}$ & $\begin{array}{c}\text { TECK } \\
\text { (CCL25) }\end{array}$ \\
\hline TIMP-1 & TIMP-2 & TNF alpha & $\begin{array}{c}\text { TNF RI } \\
\text { (TNFRSF1A) }\end{array}$ & $\begin{array}{c}\text { TNF RII } \\
\text { (TNFRSF18) }\end{array}$ \\
\hline
\end{tabular}




\section{Table1: Quantitative PCR primers.}

S Table1 List of quantitative PCR primers

\begin{tabular}{|l|l|l|l|}
\hline Gene Name & Accession Number & Forward (5'-3') & Reverse (5'-3') \\
\hline m-MMP12 & nm_001320076.1 & GAGTCCAGCCACCAACATTAC & GCGAAGTGGGTCAAAGAC \\
\hline m-GAPDH & nm.001289726.1 & CGTCCCGTAGACAAAATGGT & TCAATGAAGGGGTCGTTGAT \\
\hline m-IL6 & nm.31168 & TAGTCCTTCCTACCCCAATTTCC & TTGGTCCTTAGCCACTCCTTC \\
\hline m-MCP1(CCL2) & nm.11333 & TTAAAAACCTGGATCGGAACCAA & GCATTAGCTTCAGATTTACGGGT \\
\hline m-KC(CXCL1/IL8) & nm.008176 & CTGGGATTCACCTCAAGAACATC & CAGGGTCAAGGCAAGCCTC \\
\hline Note: m, mouse. & & & \\
\hline
\end{tabular}




\section{S $\underline{\text { Table } 2}$}

\begin{tabular}{|c|c|c|}
\hline Various studies on IL-6 & Highlights of Impact on Body Weight (fat or muscle) & PMID \\
\hline Overexpression IL-6 & $\begin{array}{l}\text { Circulating IL-6 levels were increased and the animals rapidly lost both } \\
\text { weight and body fat (often when mice bear tumors); Chronically elevated } \\
\text { IL-6 levels lead to hyperinsulinemia, reduced body weight, impaired insu- } \\
\text { lin-stimulated glucose uptake by the skeletal muscles. Systemic IL-6 over- } \\
\text { expression in tumor-bearing Apc }{ }^{\mathrm{Min} /+} \text { mice accelerated cachexia develop- } \\
\text { ment, which coincided with suppressed basal and eccentric contraction-in- } \\
\text { duced muscle protein synthesis. }\end{array}$ & $\begin{array}{l}\underline{18437347 ;} \\
29641213 \\
\end{array}$ \\
\hline $\begin{array}{l}\text { IL-6 Inhibited (Inhibit the } \\
\text { STAT3/JAK/IL-6R) }\end{array}$ & $\begin{array}{l}\text { Mice body weight increase to resistant cancer cachexia. Therapeutic ef- } \\
\text { fects of IL-6R blockade on promoting muscle regeneration. IL-6R block- } \\
\text { ade has therapeutic effects on the dystrophic skeletal muscle. }\end{array}$ & $\begin{array}{l}\underline{31002945 ;} \\
\underline{11786910}\end{array}$ \\
\hline Cytokine IL-6 Treatment & Centrally acting IL-6 exerts anti-obesity effects in rodents. & $\underline{11786910}$ \\
\hline IL-6 Neutralizing antibody Treatment & IL-6 may indirectly cause muscle wasting. & $\underline{20871233}$ \\
\hline $\begin{array}{l}\text { IL-6 KO under } \\
\text { tumor-bearing }\end{array}$ & $\begin{array}{l}\text { Centrally acting IL-6 exerts anti-obesity effects in rodents; Apc }\left({ }^{\mathrm{Min} /+}\right) / \mathrm{IL}- \\
6\left(^{(--)}\right) \text {mice did not lose gastrocnemius muscle mass or epididymal fat pad } \\
\text { mass while overall polyp number decreased compared with Apc }\left({ }^{\mathrm{Min} /+}\right) \\
\text { mice. }\end{array}$ & $\begin{array}{l}\underline{11786910} \\
\underline{18056981}\end{array}$ \\
\hline
\end{tabular}


bioRxiv preprint doi: https://doi.org/10.1101/2021.01.29.428838; this version posted January 30,2021 . The copyright holder for this preprint (which was not certified by peer review) is the author/funder, who has granted bioRxiv a license to display the preprint in perpetuity. It is made available under aCC-BY 4.0 International license.

61

\begin{tabular}{|l|l|l|}
\hline IL-6 overexpression & Administration of an IL-6 receptor antibody to cachectic male Apc ${ }^{\text {Min/+ }}$ mice & $\underline{25555992 ;}$ \\
can attenuate further cachexia progression to increase body weight. IL-6 & over-expression in pre-cachectic mice accelerated body weight loss and \\
under tumor-bearing & bearing mice. & $\underline{18056981}$ \\
\hline
\end{tabular}




\section{Table 3: Abbreviations}

\begin{tabular}{|c|c|}
\hline Abbreviations & Full name \\
\hline MMP12 & Matrix Metalloproteinases 12 \\
\hline $\mathrm{CRC}$ & Colorectal Cancer \\
\hline $\mathrm{CAC}$ & Cancer Cachexia \\
\hline $\mathrm{Apc}^{\mathrm{Min} /+} ; \mathrm{MMP}^{-} 2^{-}$ & $\mathrm{Apc}^{\mathrm{Min} /+} ; \mathrm{MMP} 12^{-/-}$mice \\
\hline WAT & White Adipose Tissue \\
\hline BAT & Brown Adipose Tissue \\
\hline HRP & Horseradish Peroxides \\
\hline $\mathrm{H} \& \mathrm{E}$ & Hematoxylin \& Eosin \\
\hline qPCR & Quantitative Polymerase Chain Reaction \\
\hline IHC & Immunohistochemistry \\
\hline IF & Immunofluorescence \\
\hline PBS & Phosphate Buffered Saline \\
\hline MCP1(CCL2) & Monocyte Chemoattractant Protein 1 \\
\hline $\mathrm{KC}(\mathrm{CXCL} 1)$ & Keratinocyte-derived Chemokine \\
\hline RANTES & Regulated upon Activation, Normal T Cell Expressed and Presumably Secreted \\
\hline IL-6 & Interleukin 6 \\
\hline IGF-1 & Insulin-like Growth Factor 1 \\
\hline
\end{tabular}


Figure 1

A
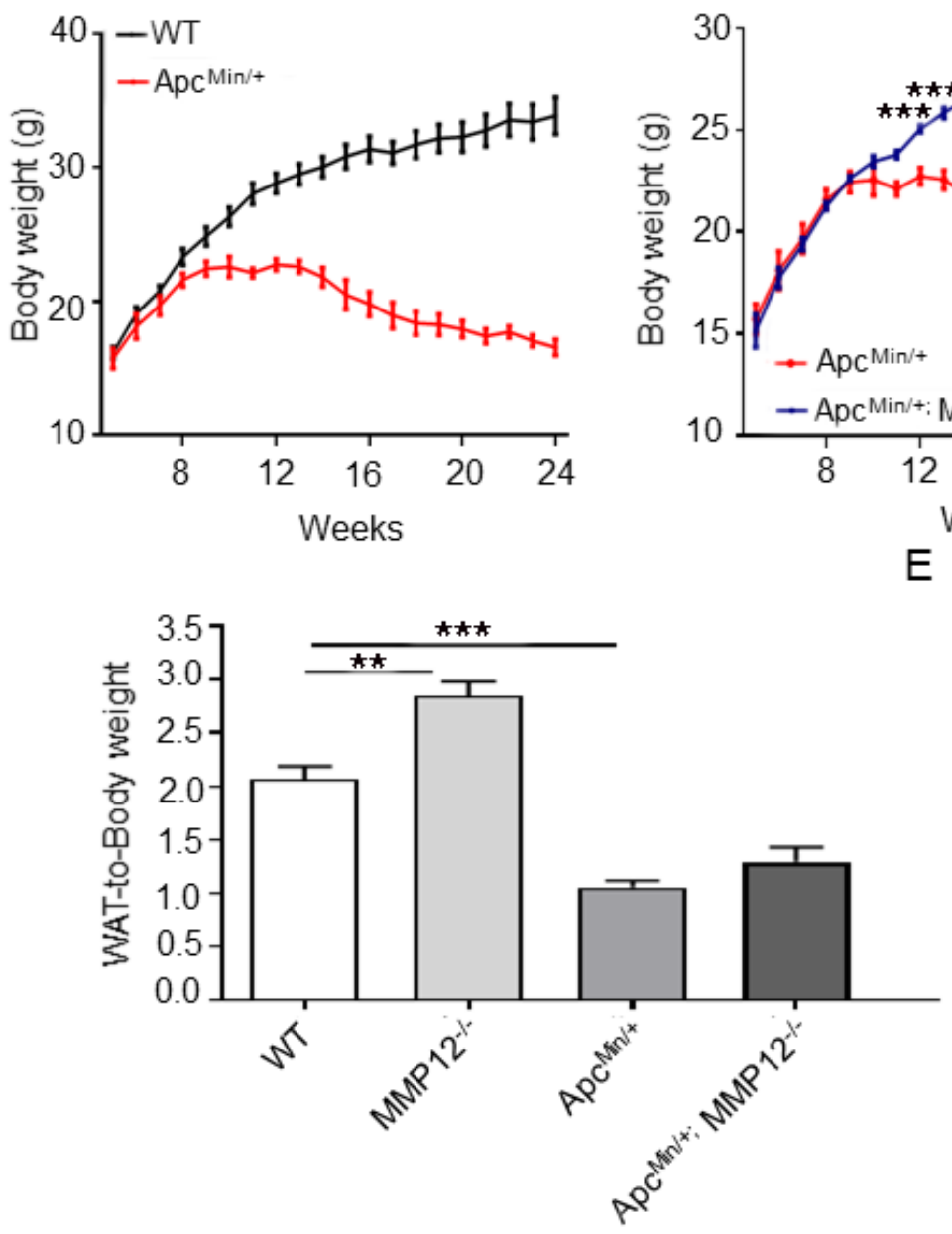

F

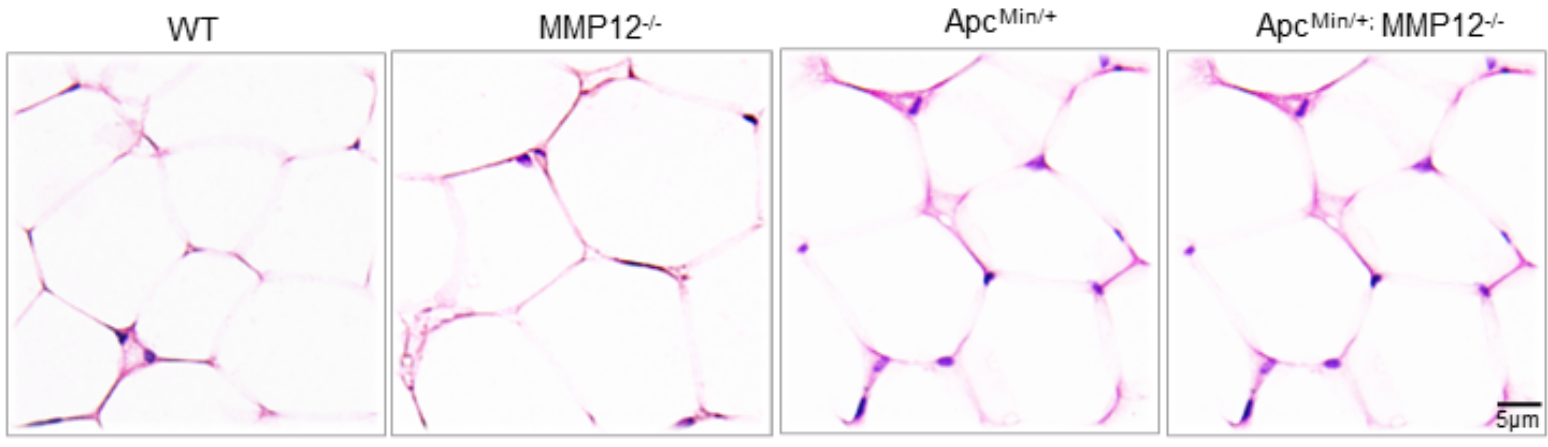

$\mathrm{H}$

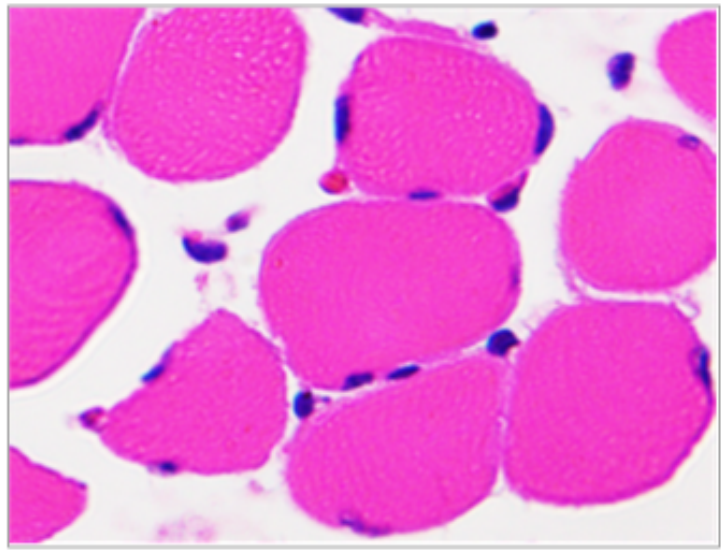

$\mathrm{Apc} \mathrm{Min} /+^{-}$

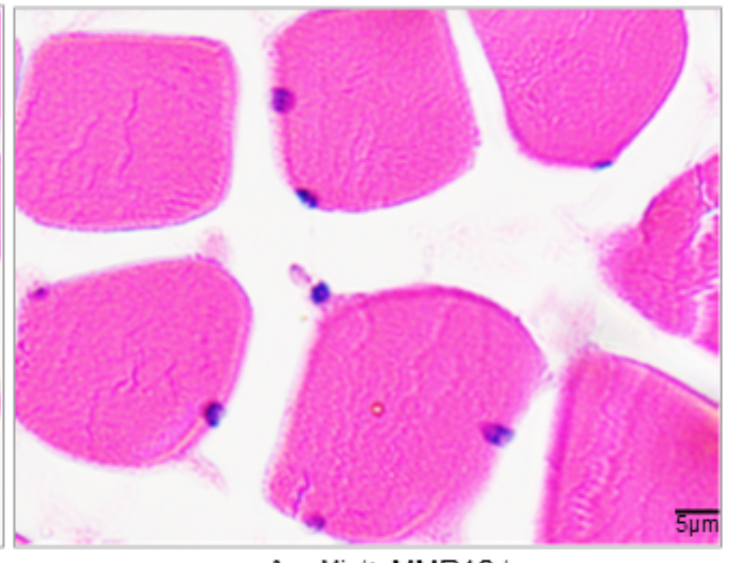

$\mathrm{Apc}^{\mathrm{Min} /+} \mathrm{MMP} 12^{-/-}$

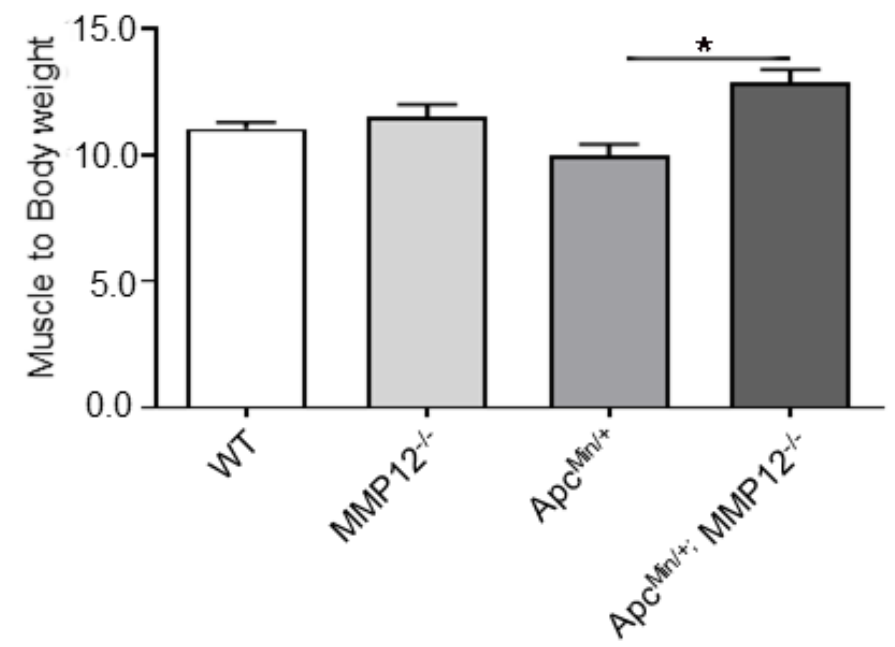

G

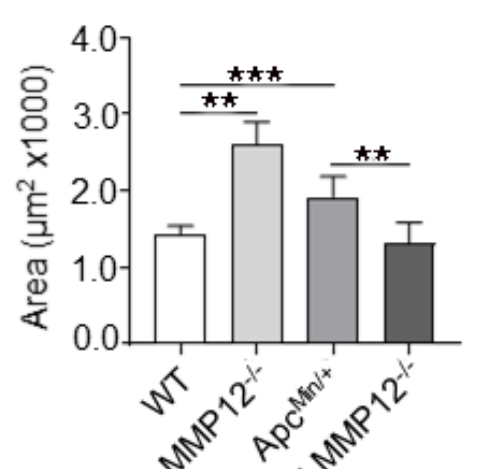

I
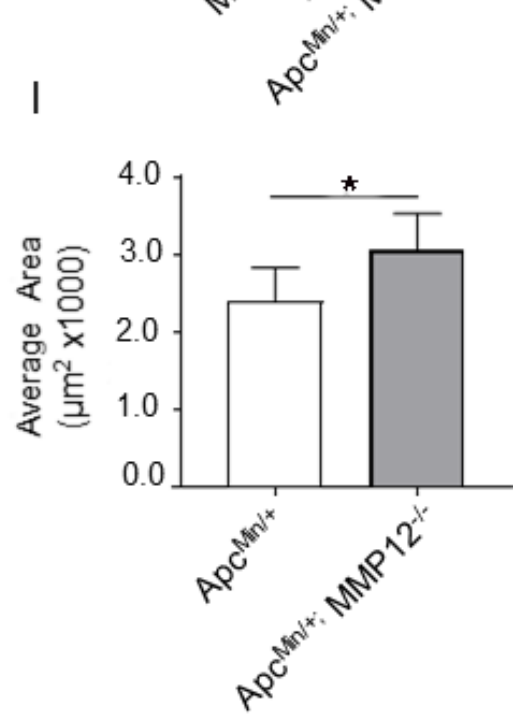
Figure 2
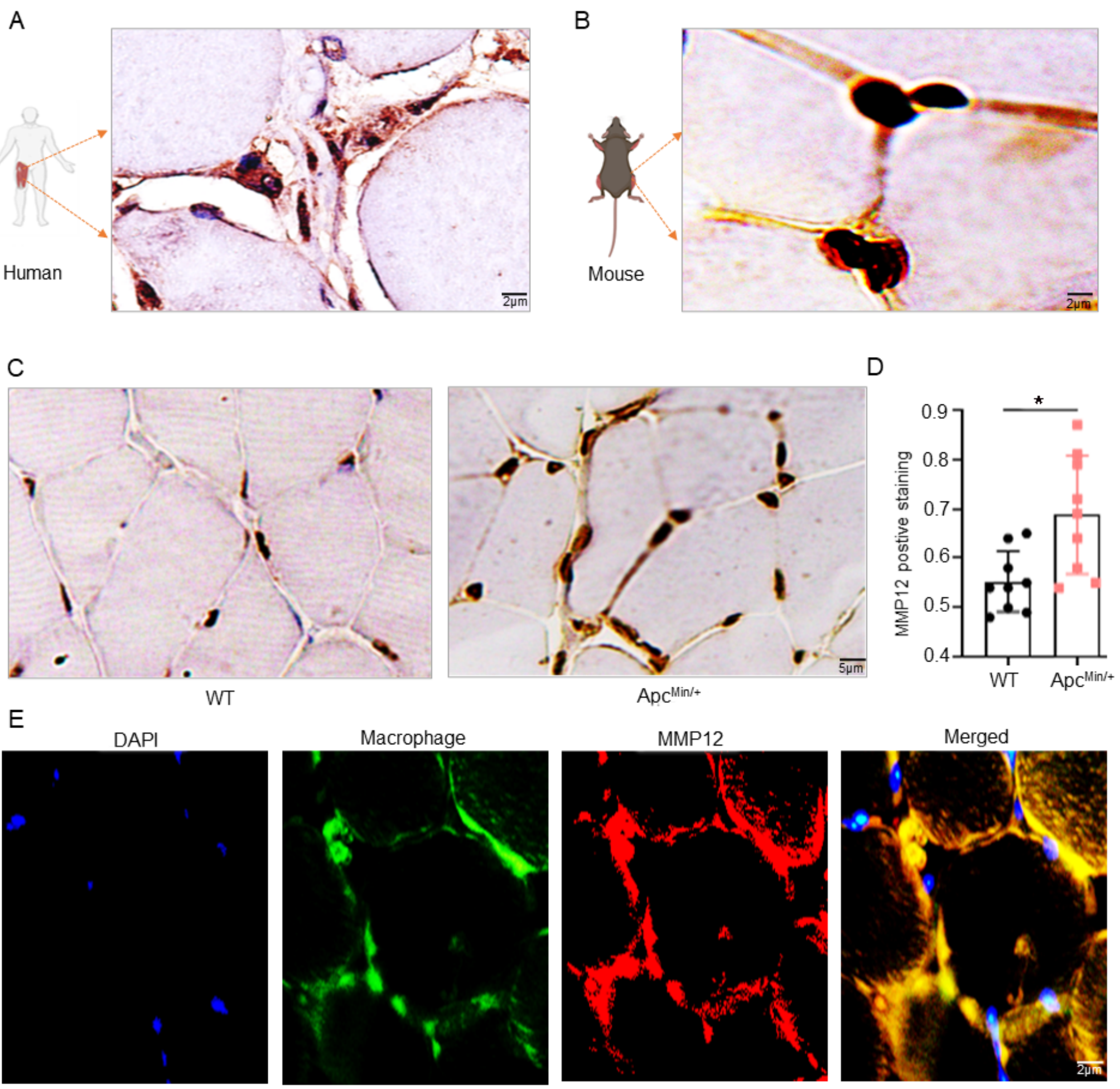

F

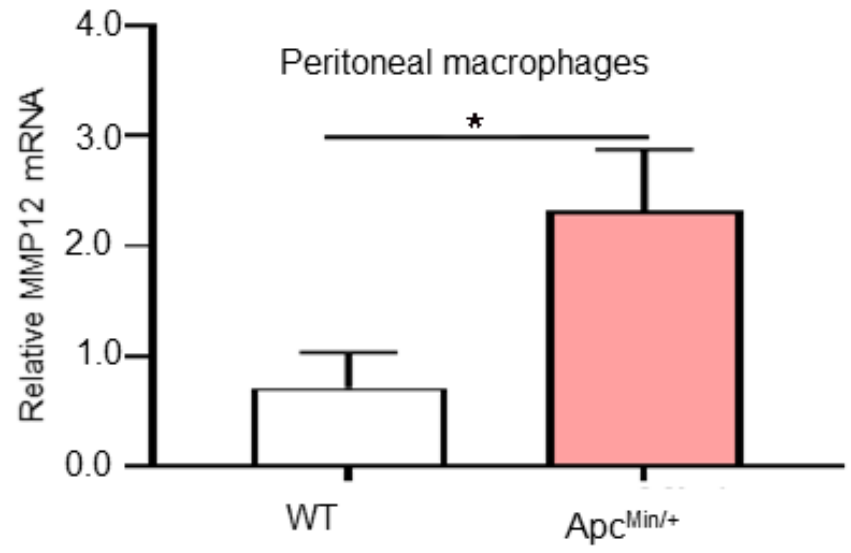

G

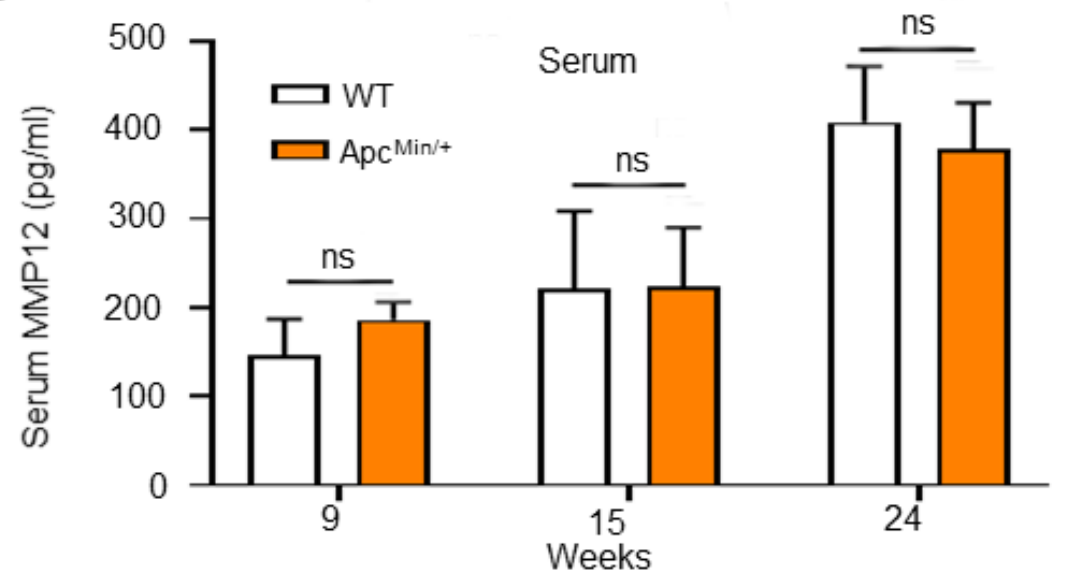


Figure 3

A

B

C
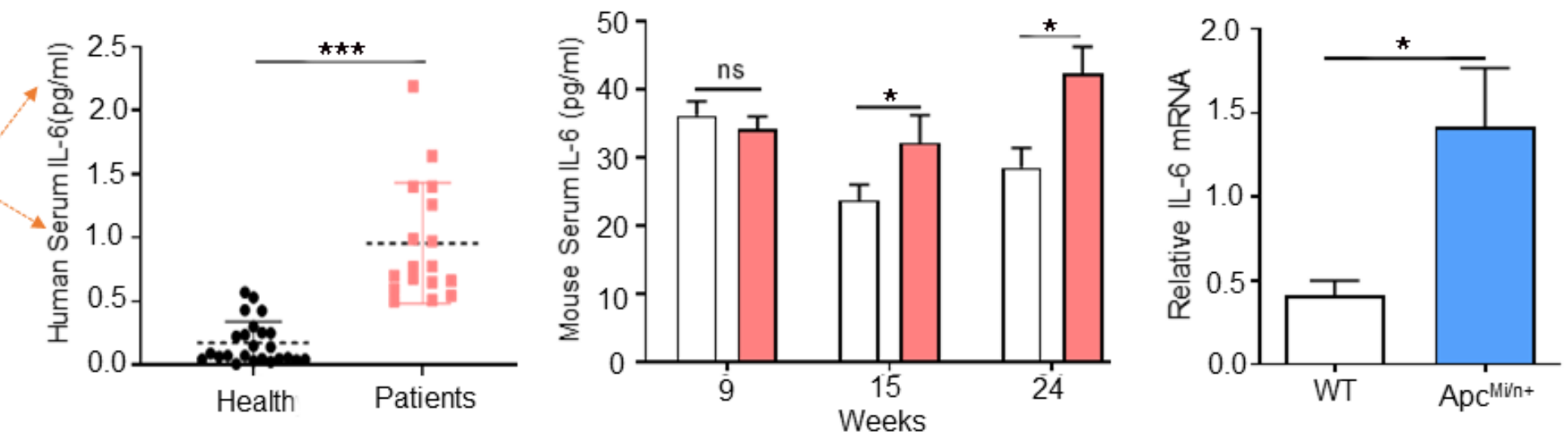

D
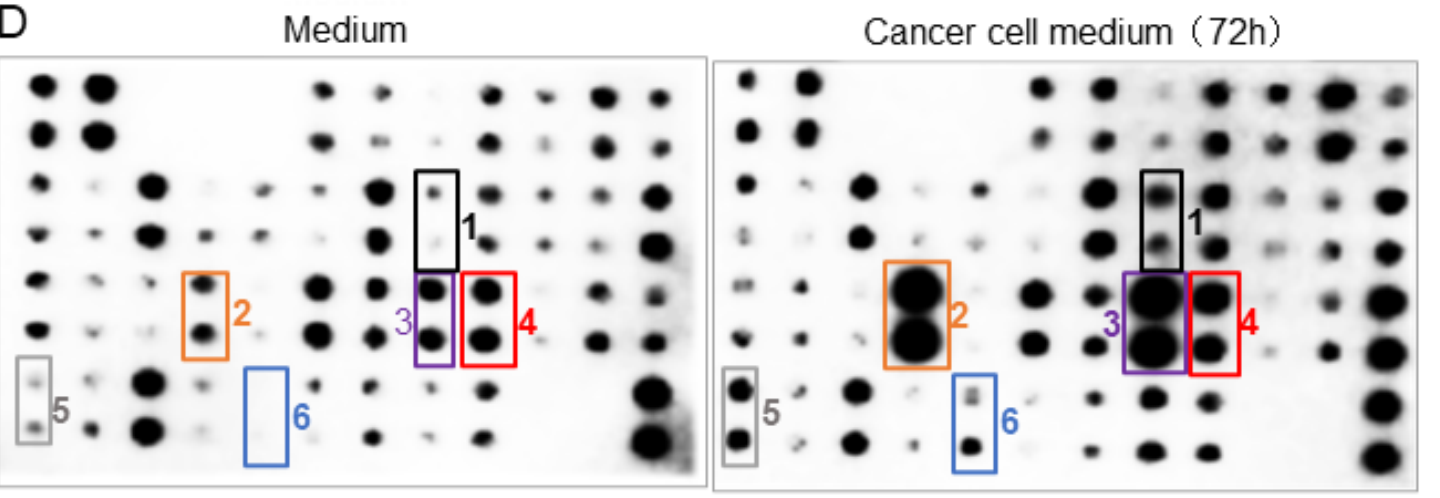

E

1.M-CSF

2. $\mathrm{KC}(\mathrm{IL}-8)$

3.MCP1(CCL2)

4.IL-6

5. RANTES

6.TMP1

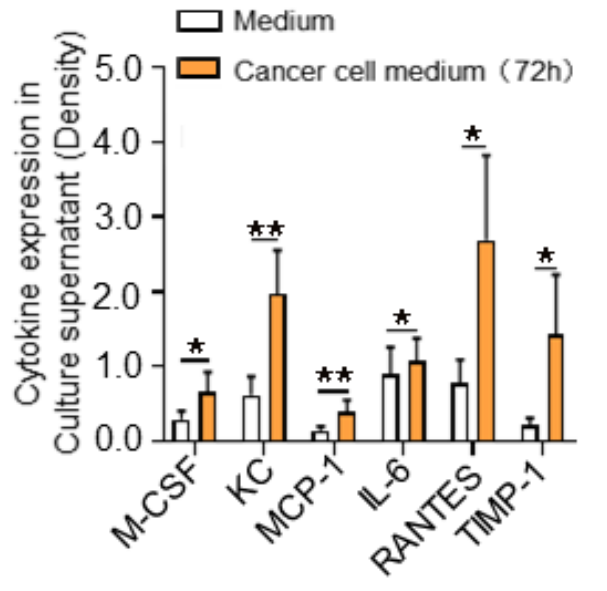




\section{Figure 4}

A

Tumor cells co-culture with Macrophages

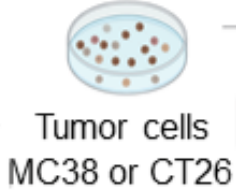

$\because \because \because$

Macrophages

RAW264.7

WB

co-culture
B

MMP12

Macrophages in lower chamber

F

IL-6 Treatment Macrophages Protocol

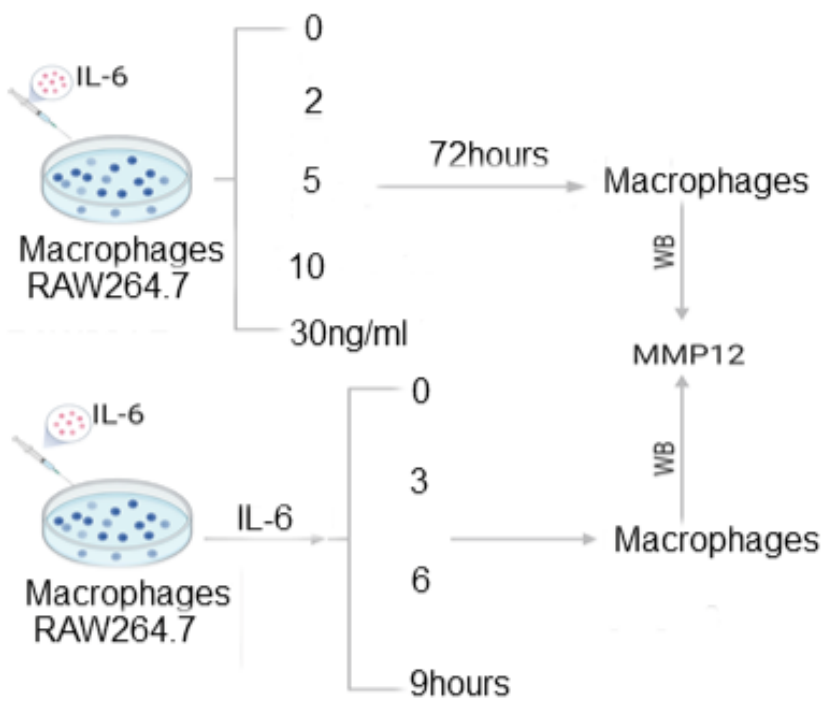

$\mathrm{K}$

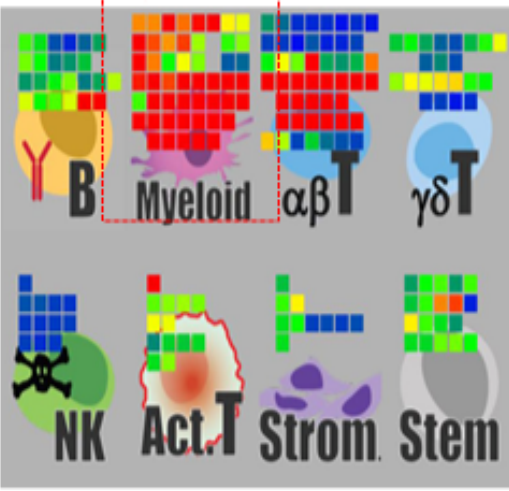

High

Medium

Low

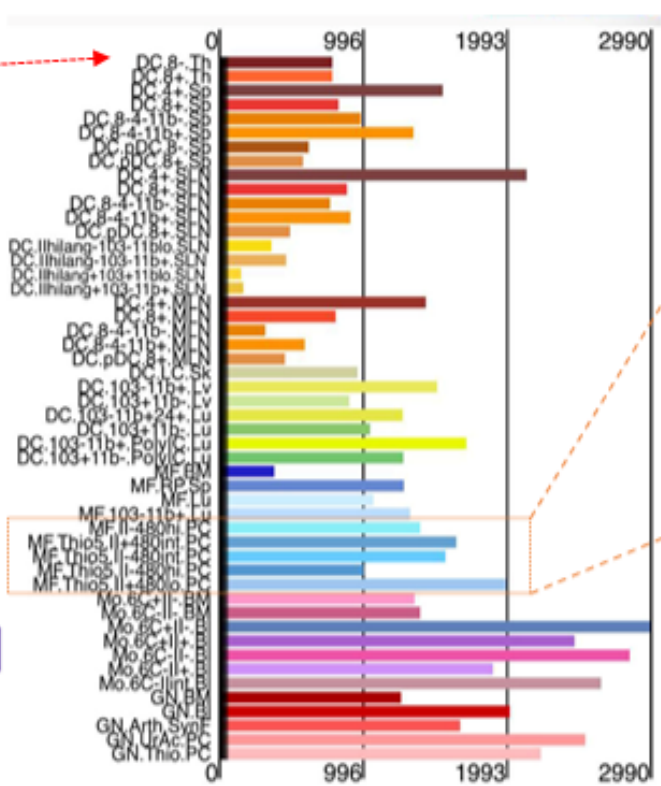

C
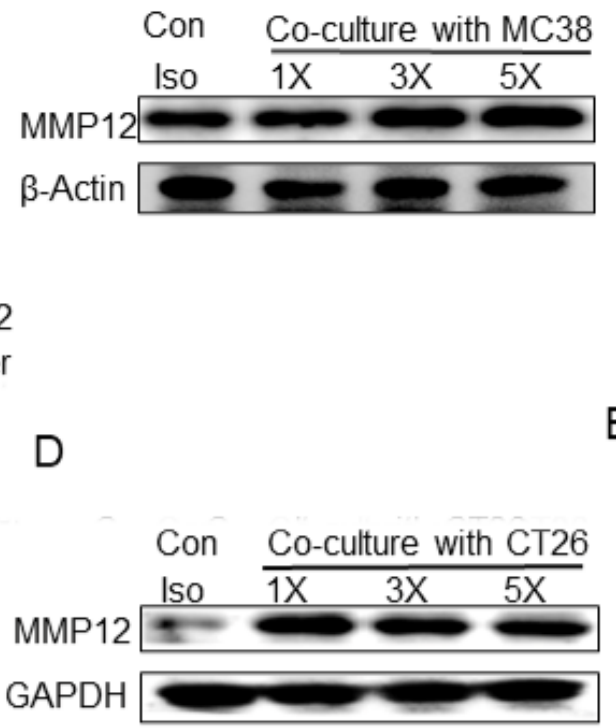

$\mathrm{H}$
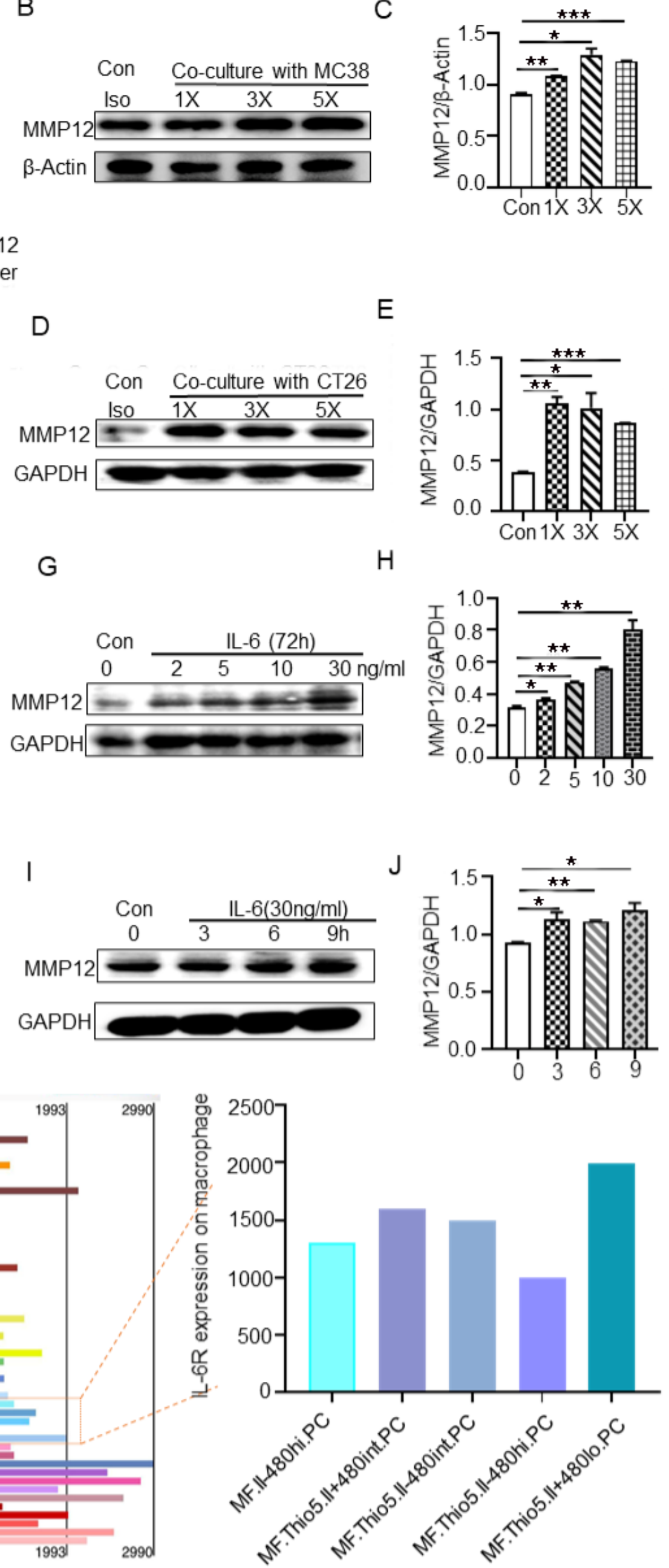
Figure 5

A

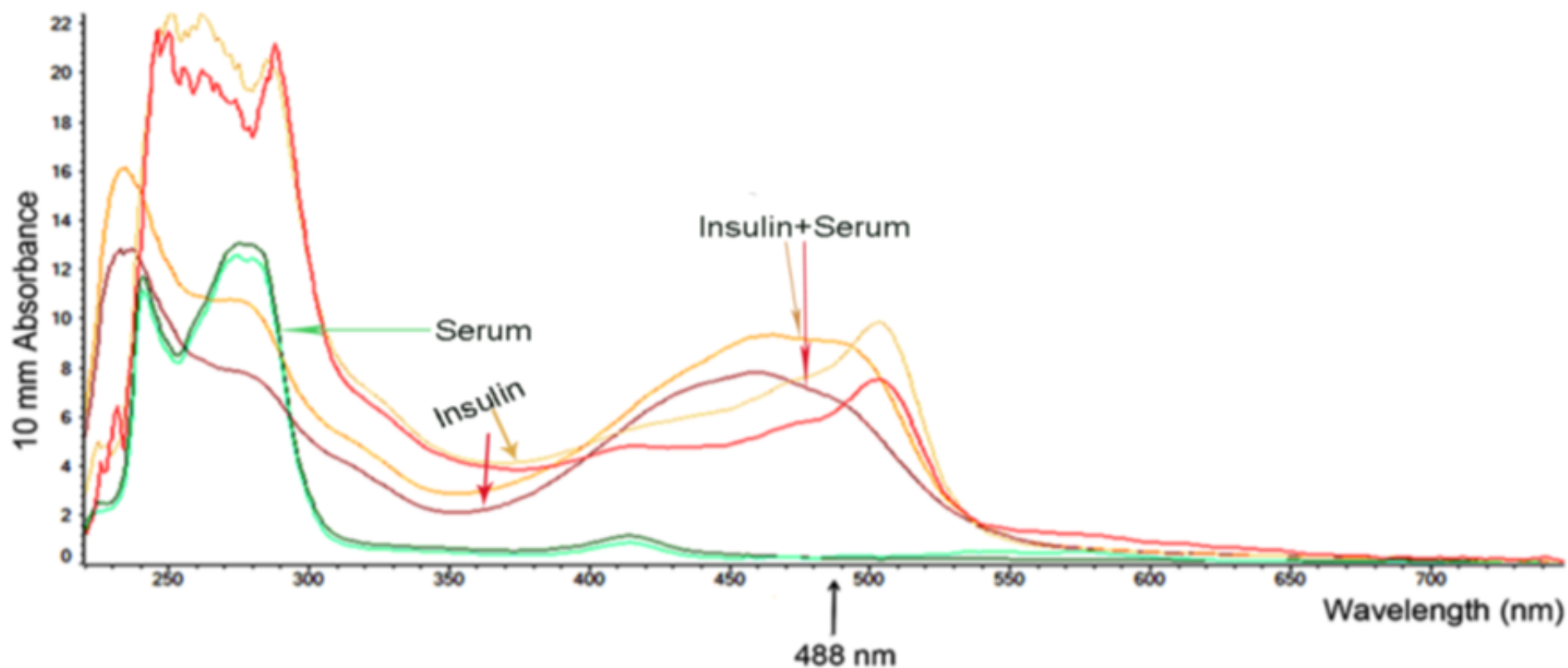

B

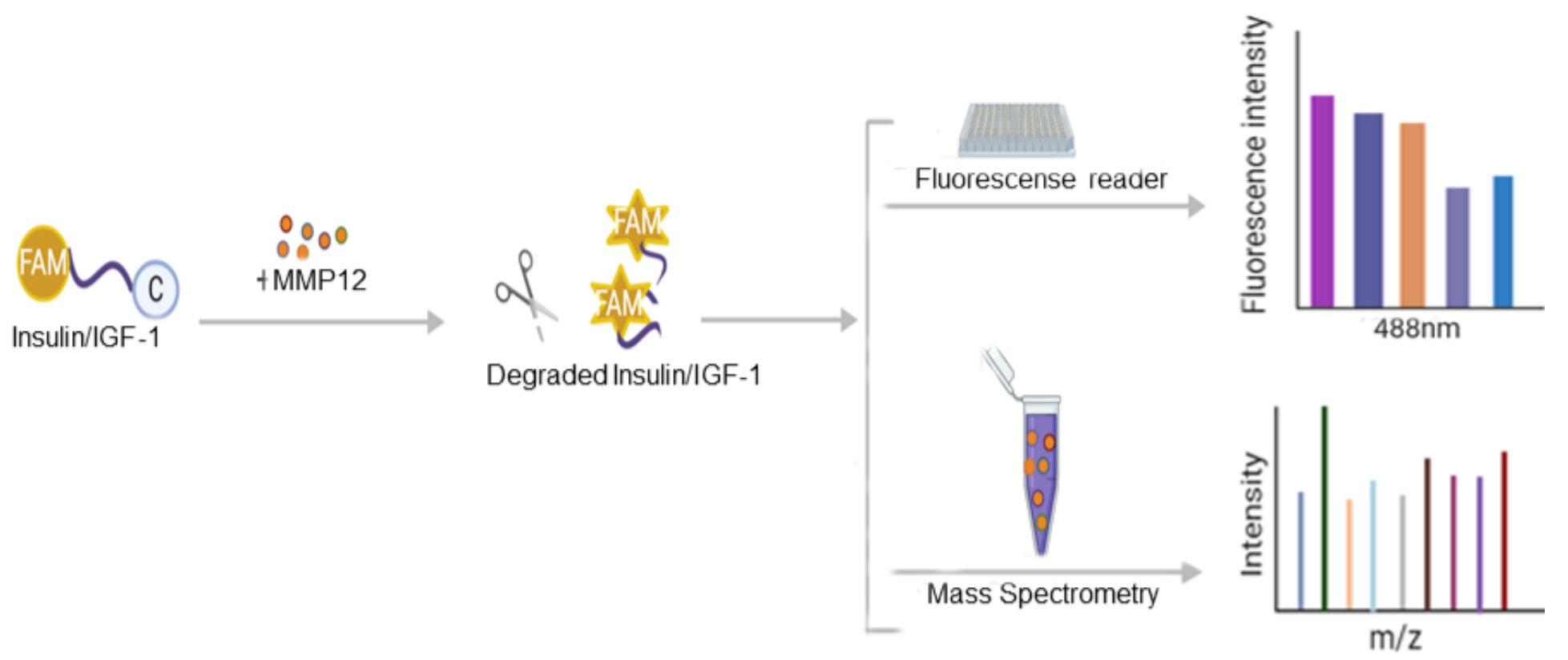

C
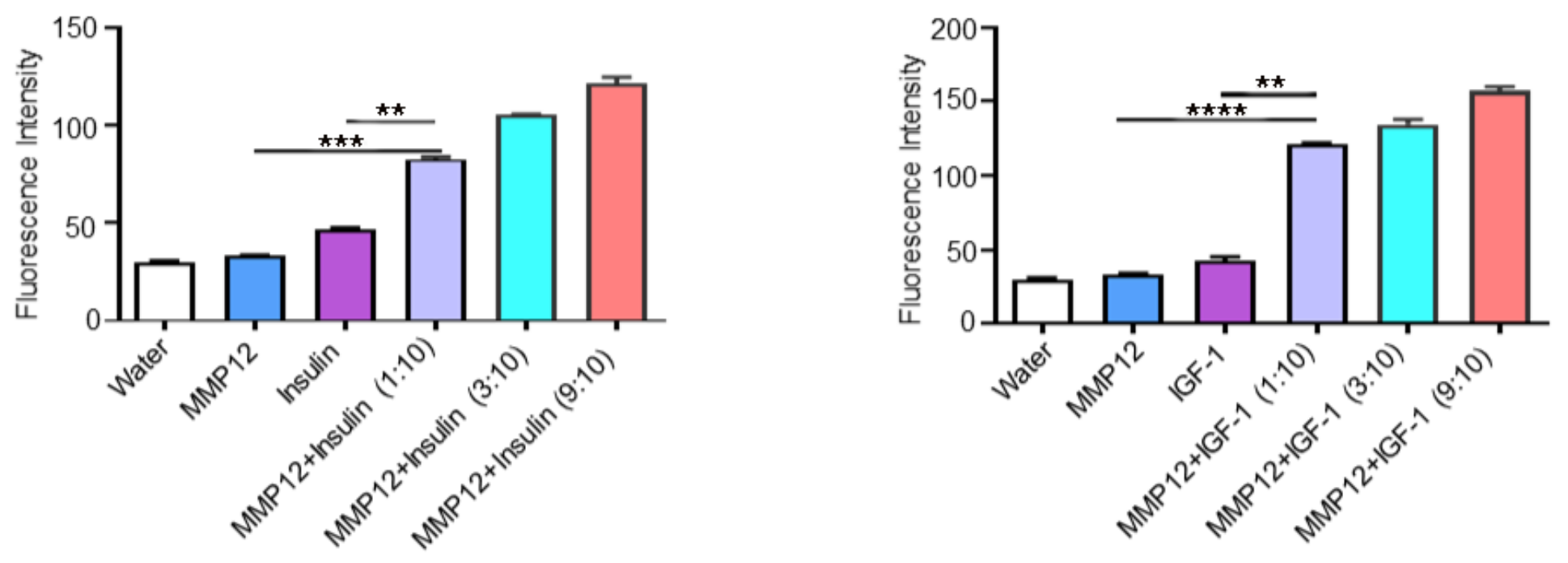
Figure 6

A
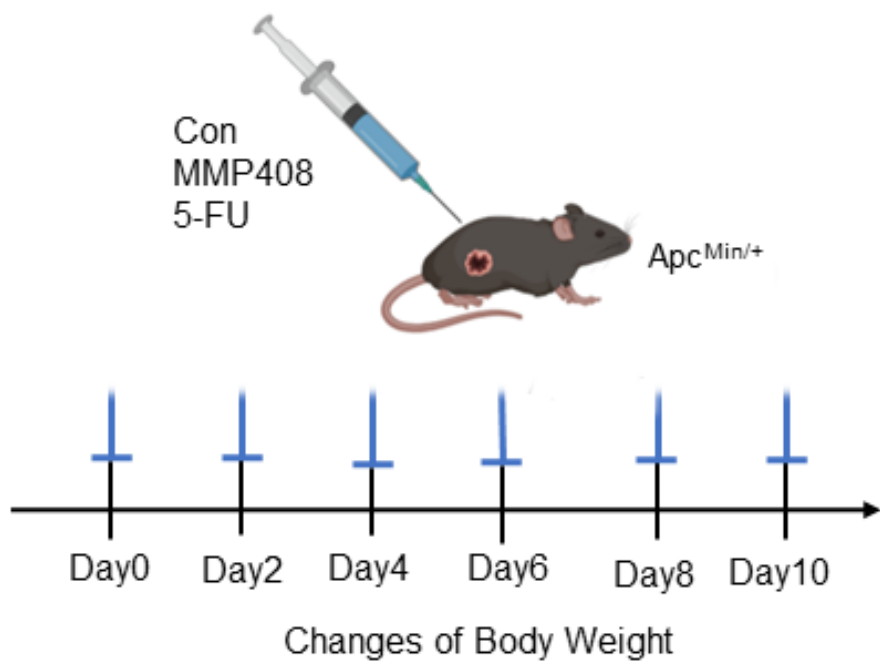

B

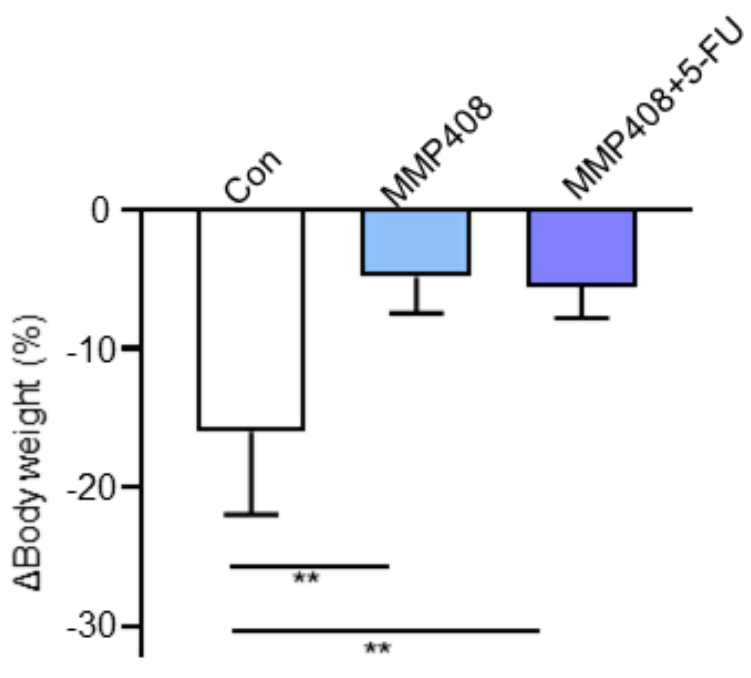


Figure 7

\section{Tumor-derived IL-6 to MMP12 in Muscle macrophage Metastasis}

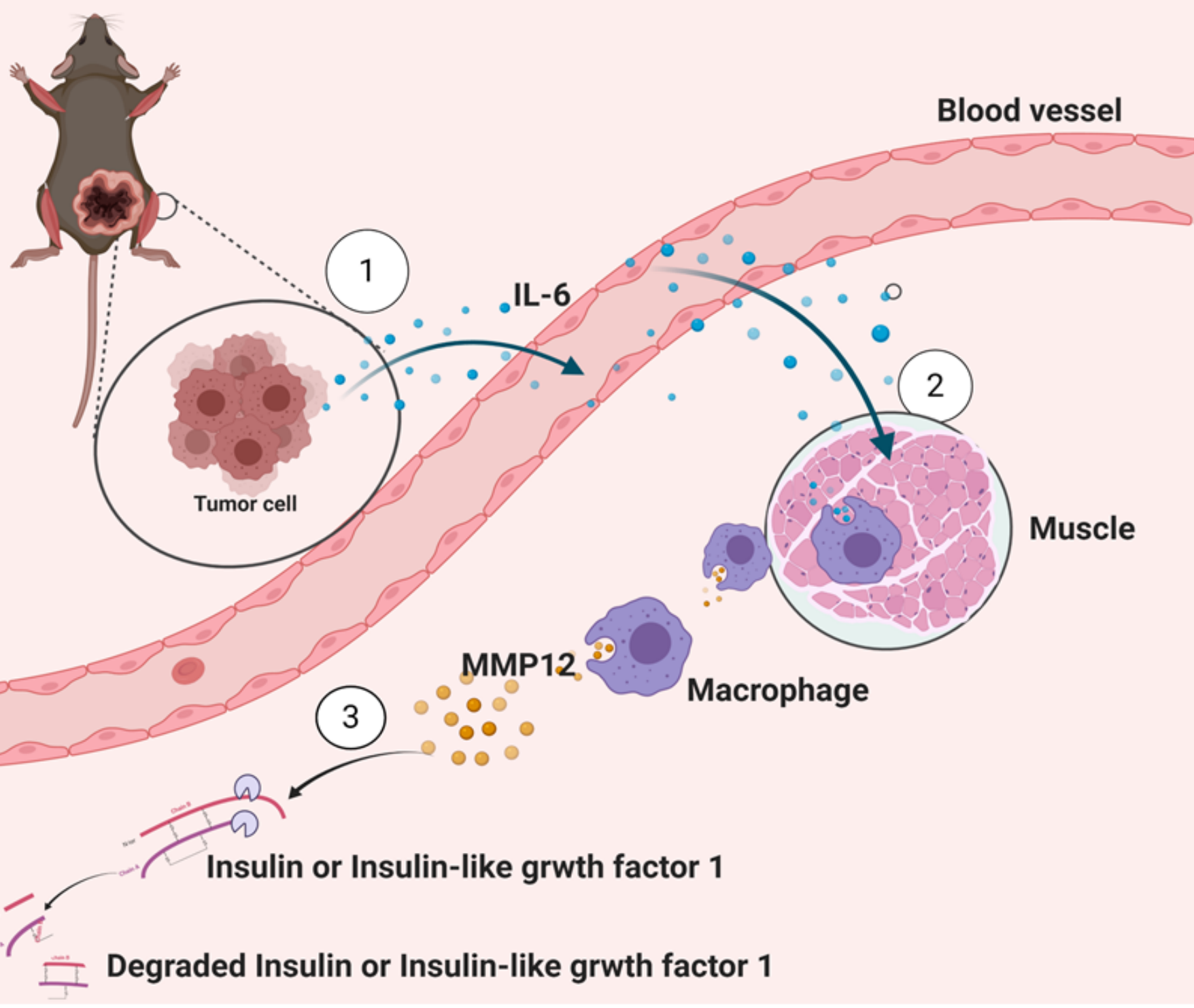




\section{Figure S1}

A

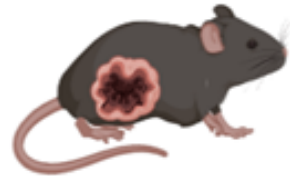

$\mathrm{Apc}^{\mathrm{Min} /+}$
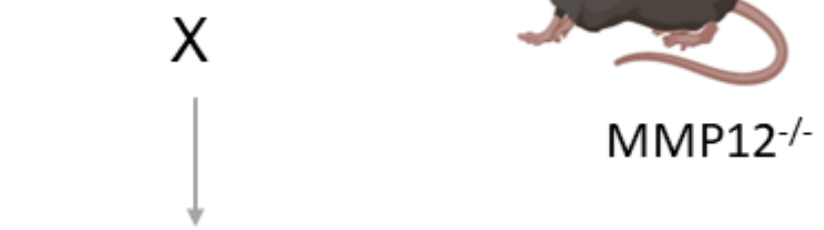

$$
\mathrm{Apc}^{\mathrm{Min} /+} ; \mathrm{MMP}^{2 /-}
$$

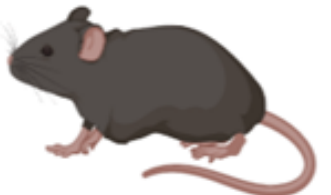

MMP12/-

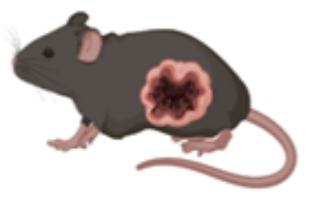

B

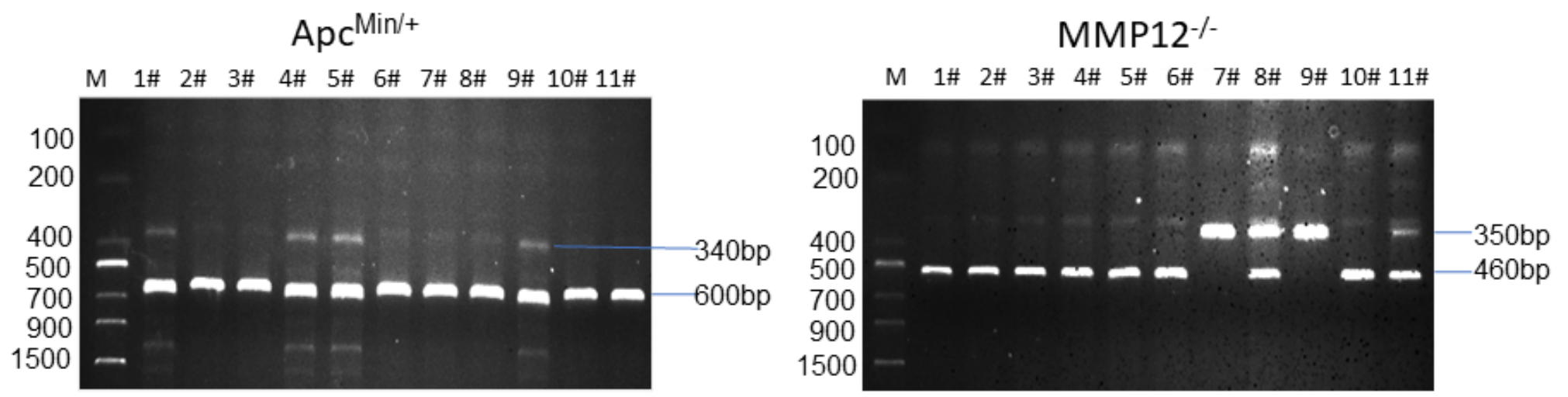


Figure S2

A

Insulin
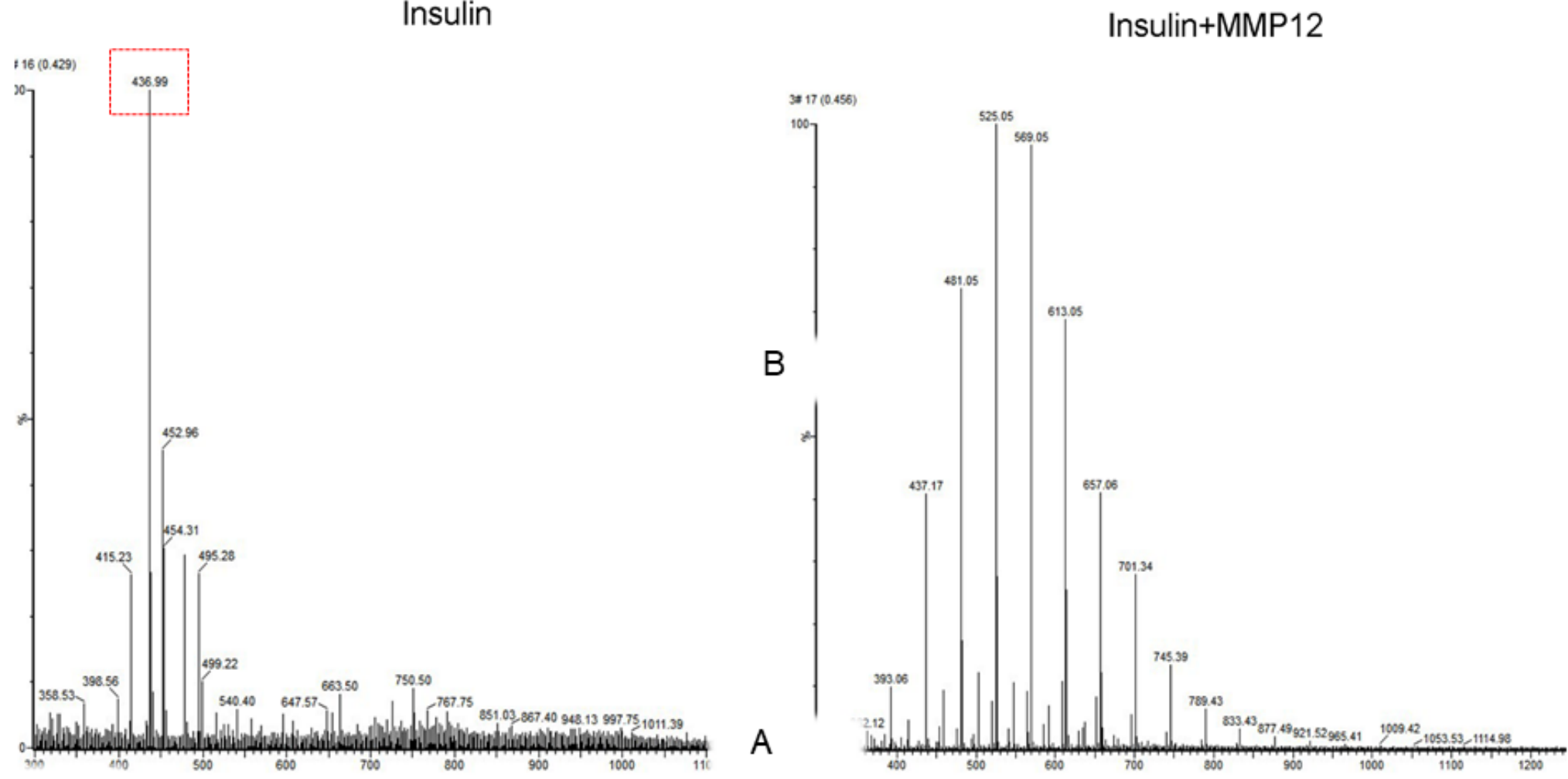

B

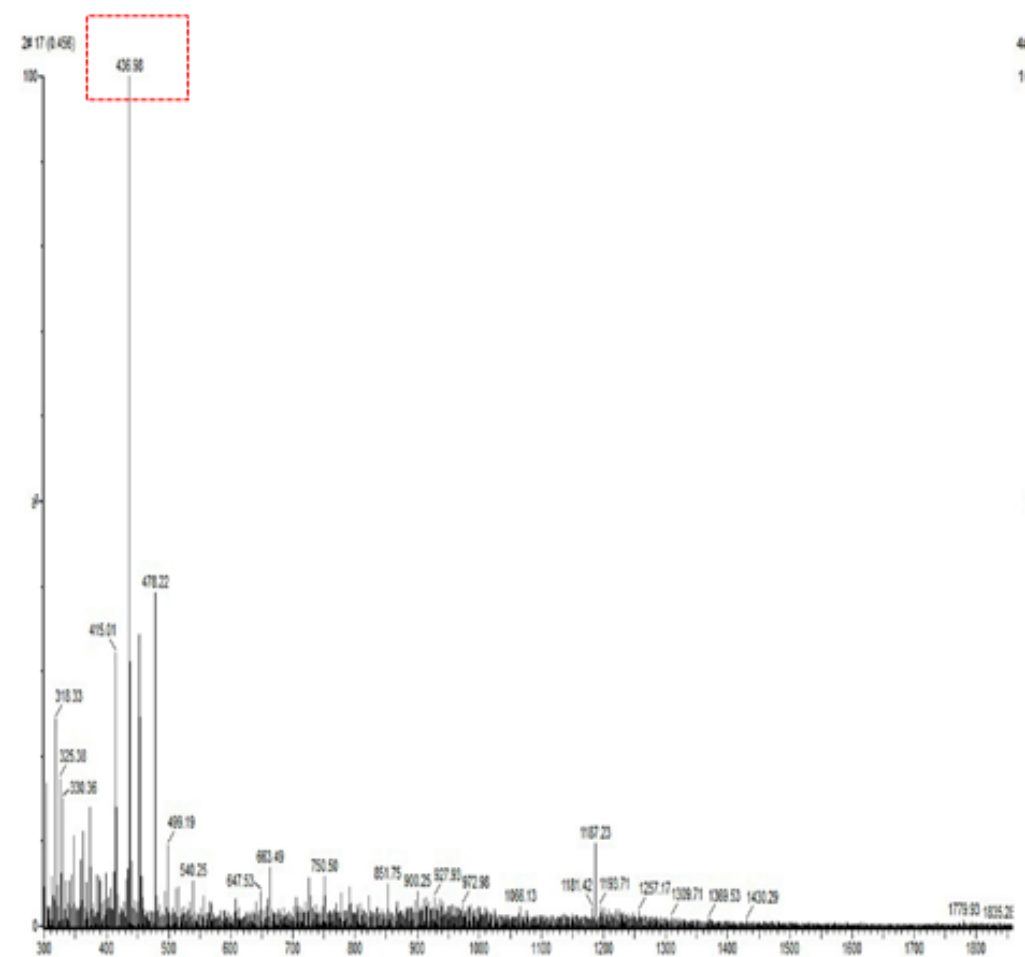

IGF-1

IGF-1+MMP12

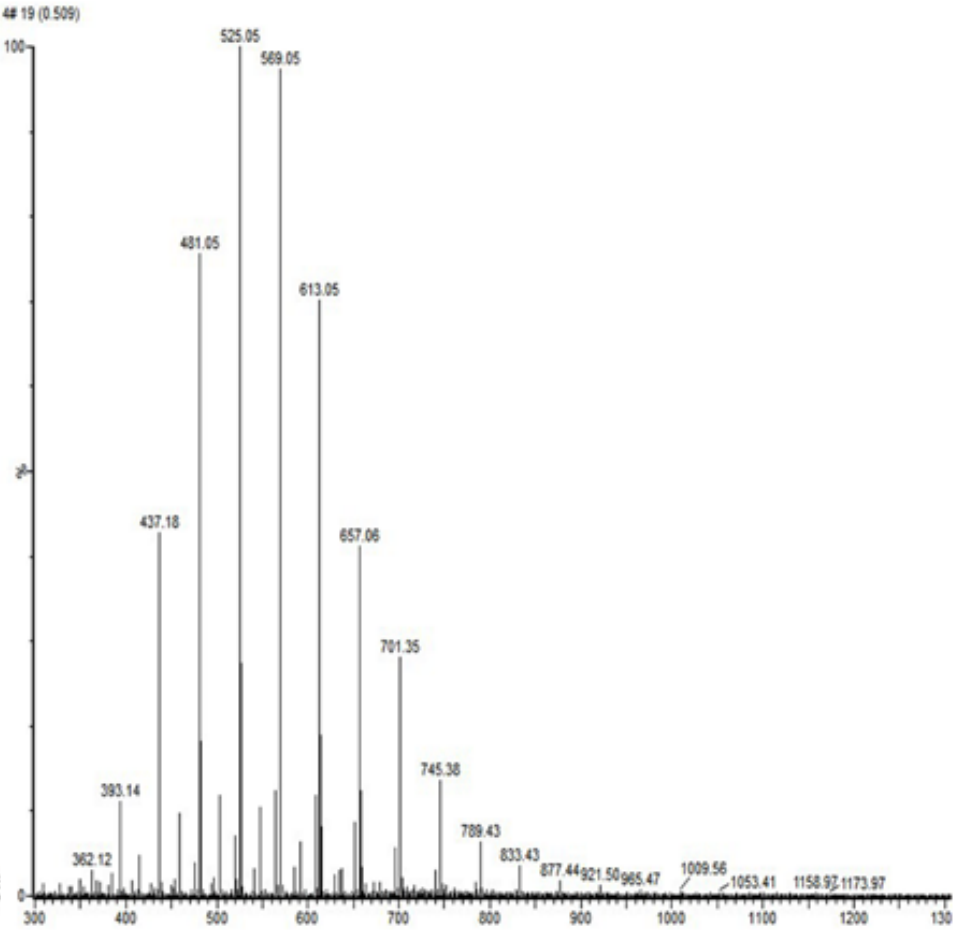


Figure S3

A

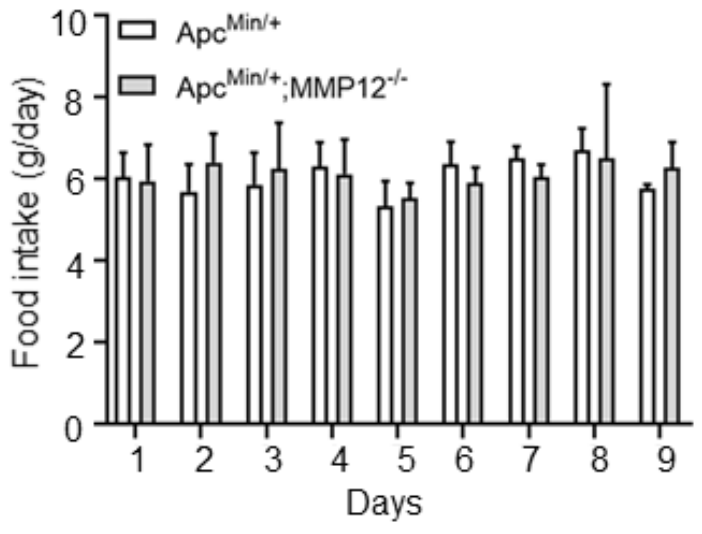

B

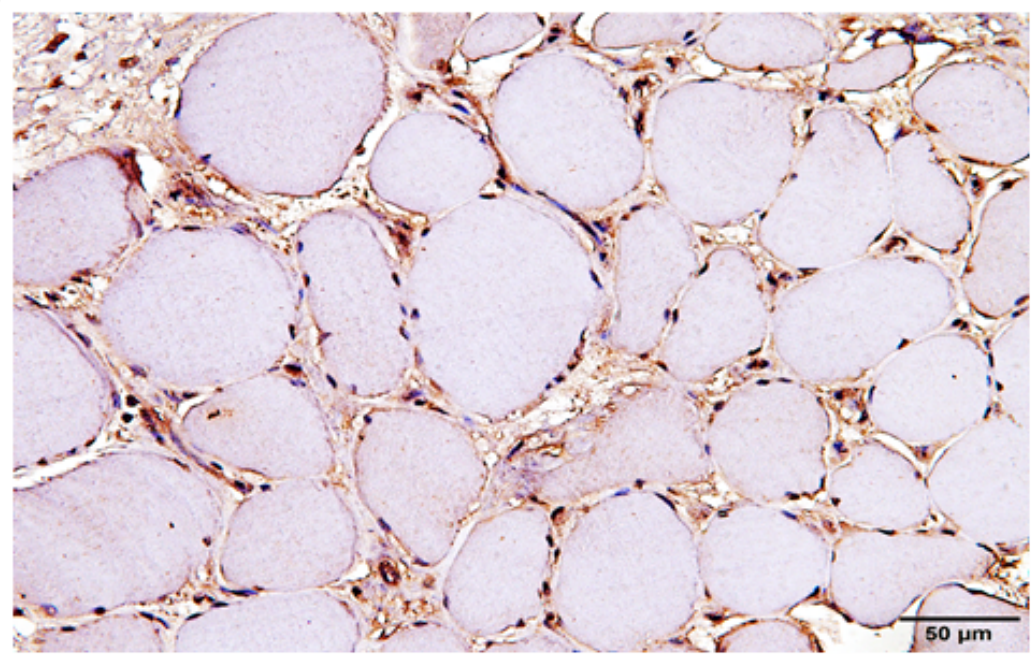

C

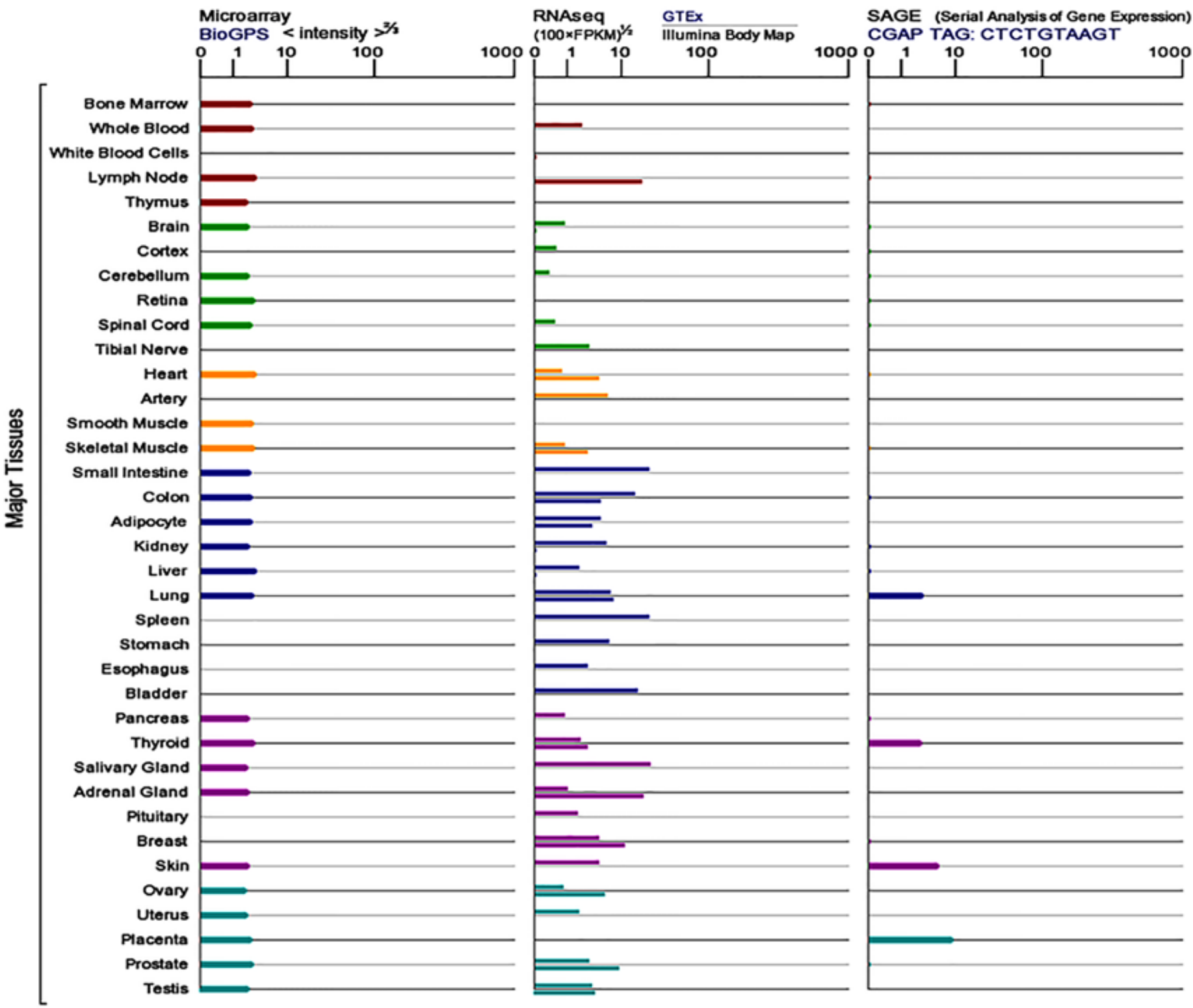


Figure S4

A

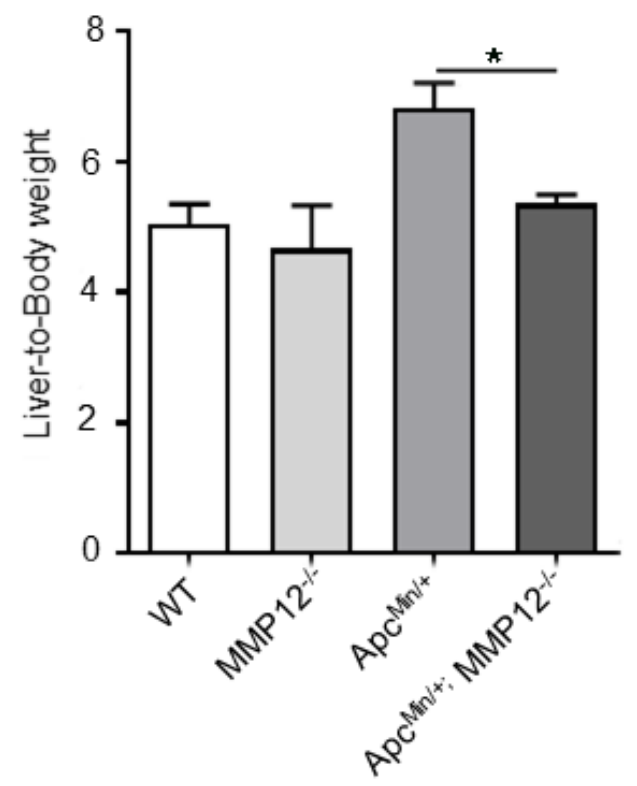

D

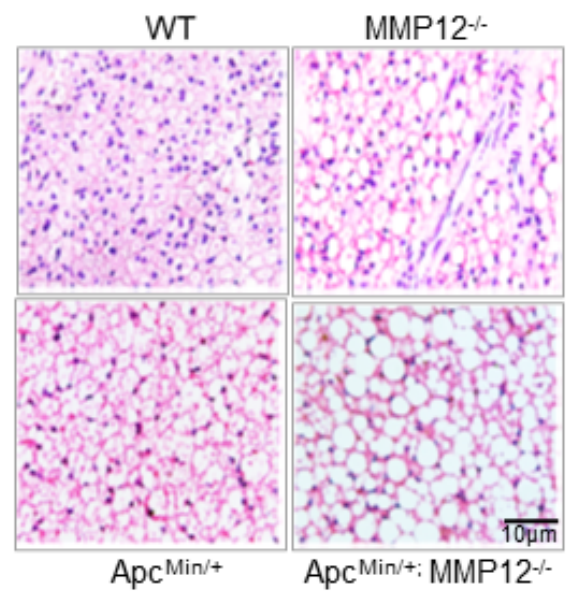

E

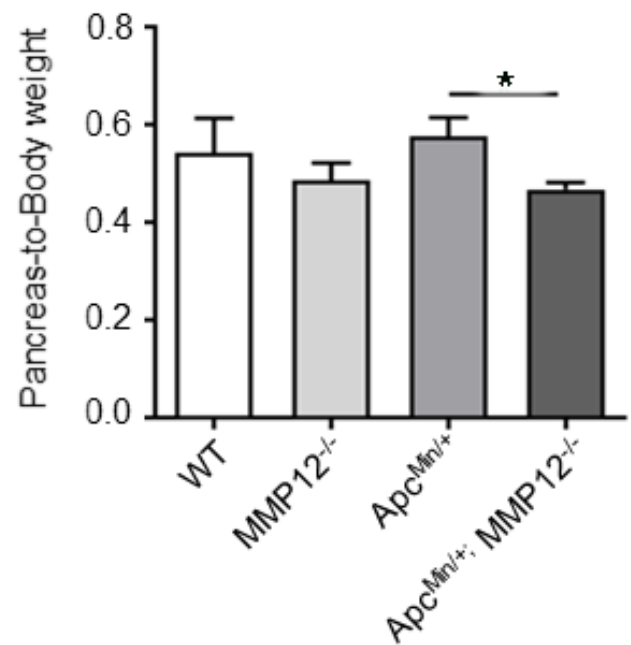

C

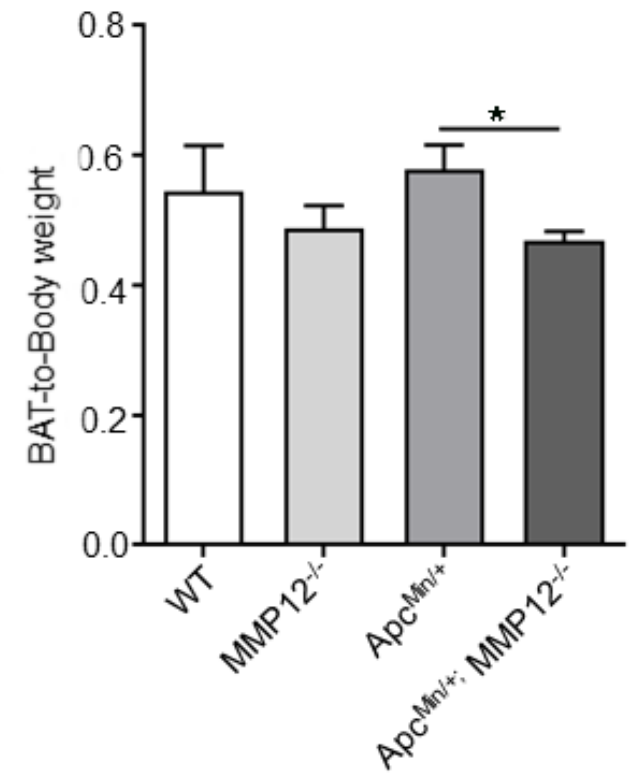

F
G

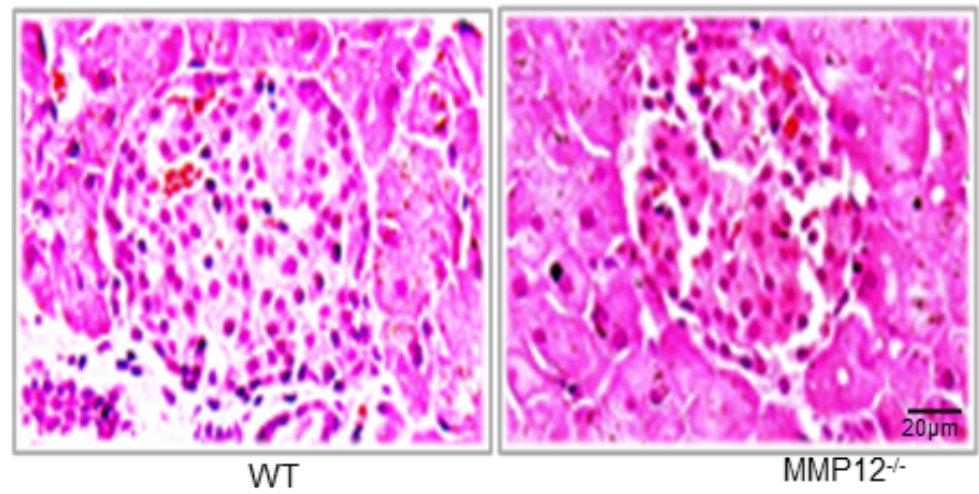

$\mathrm{H}$

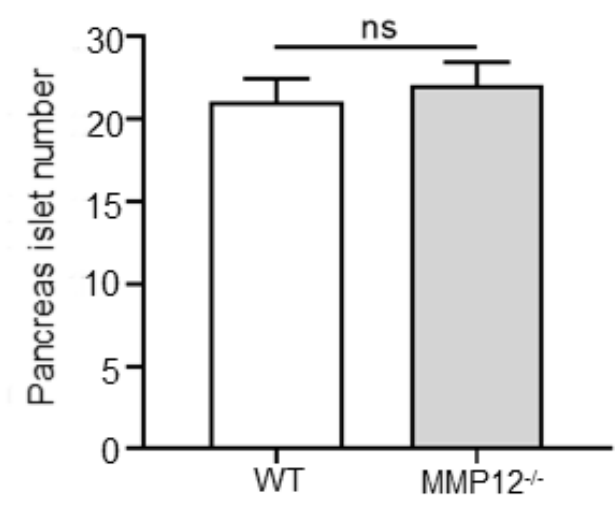

Insulin

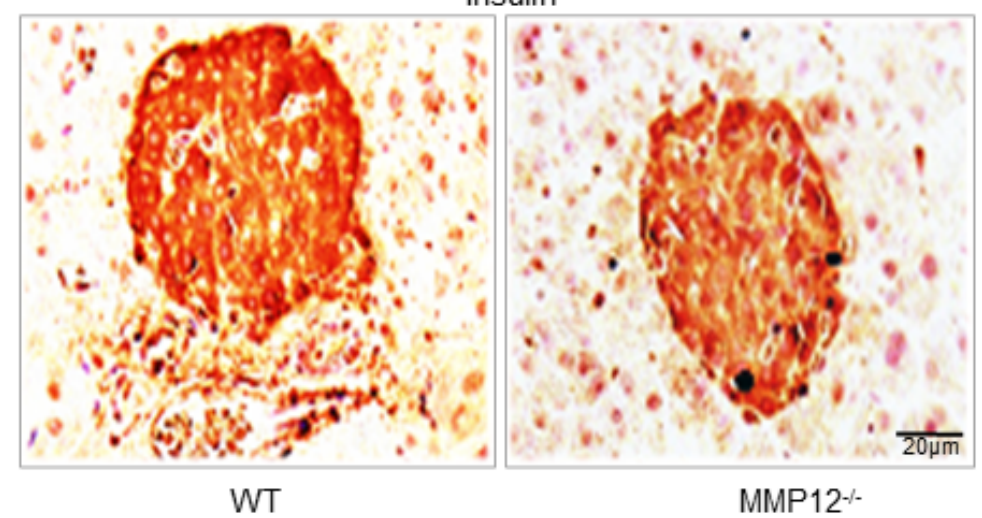


Figure S5

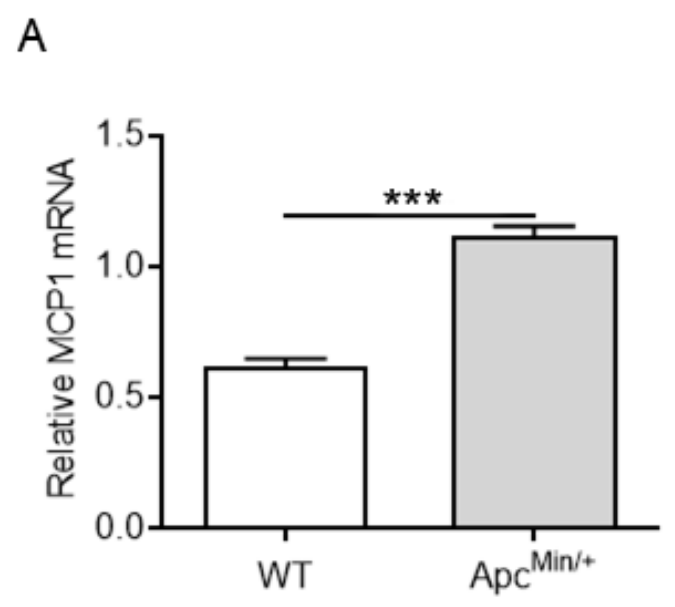

B

C
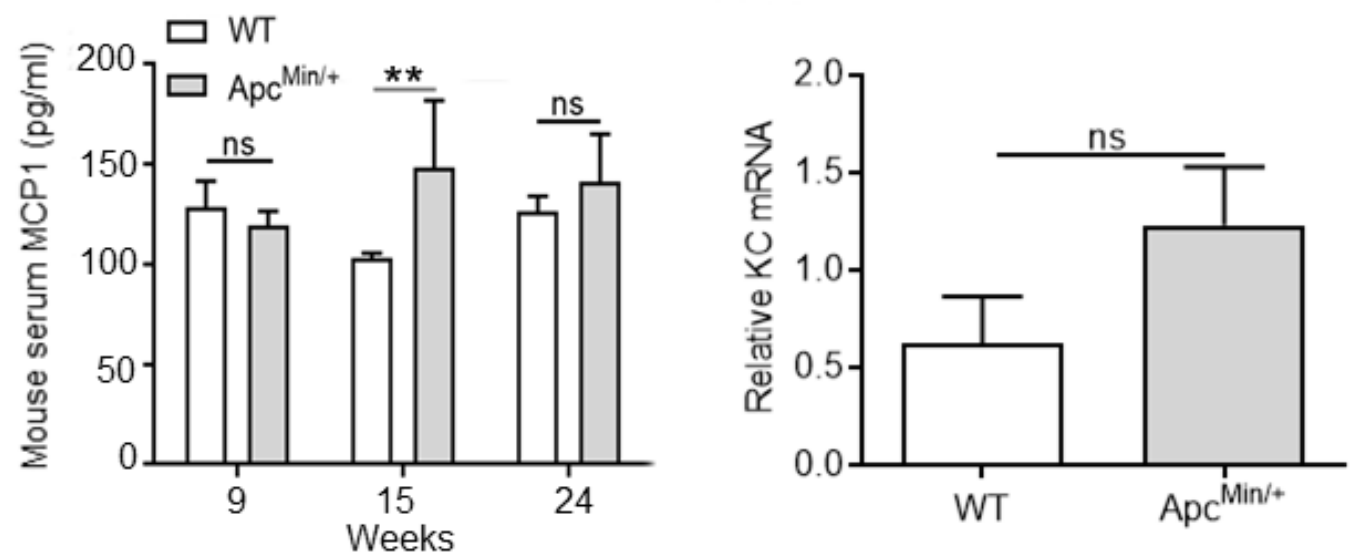

D

E
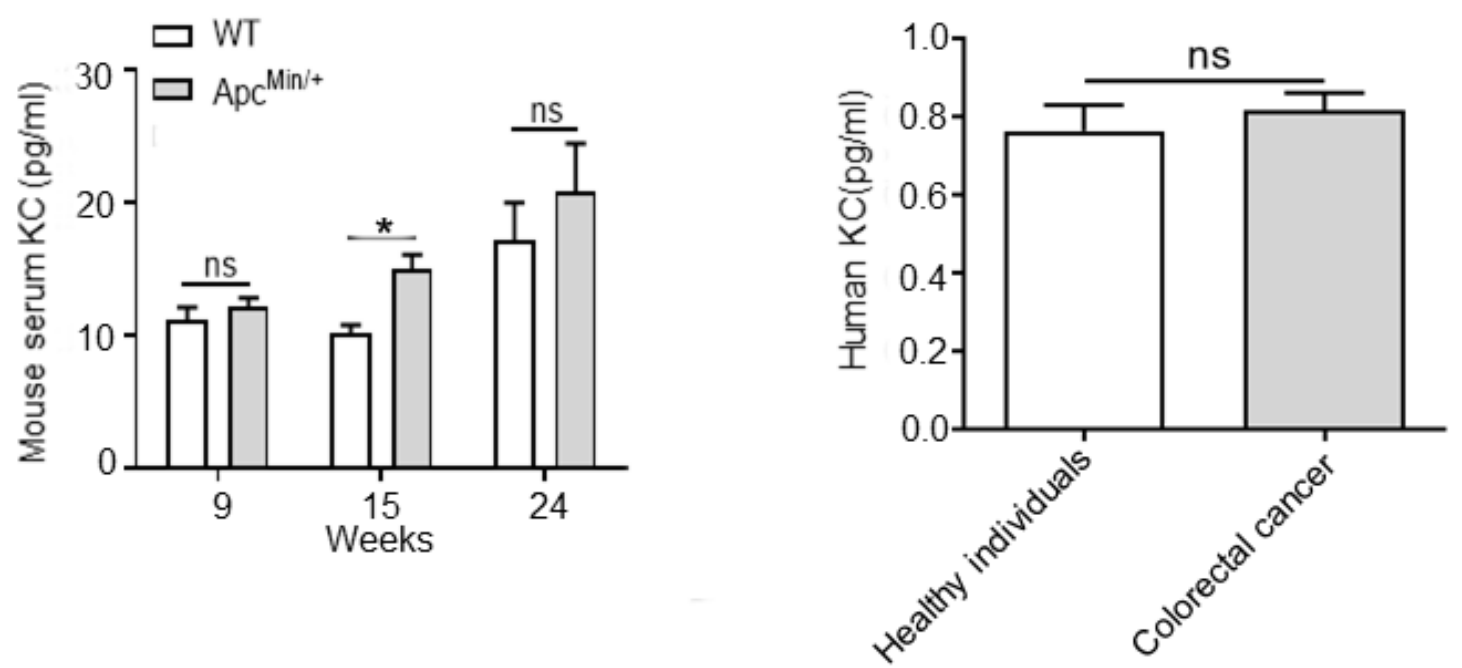
Figure S6

A
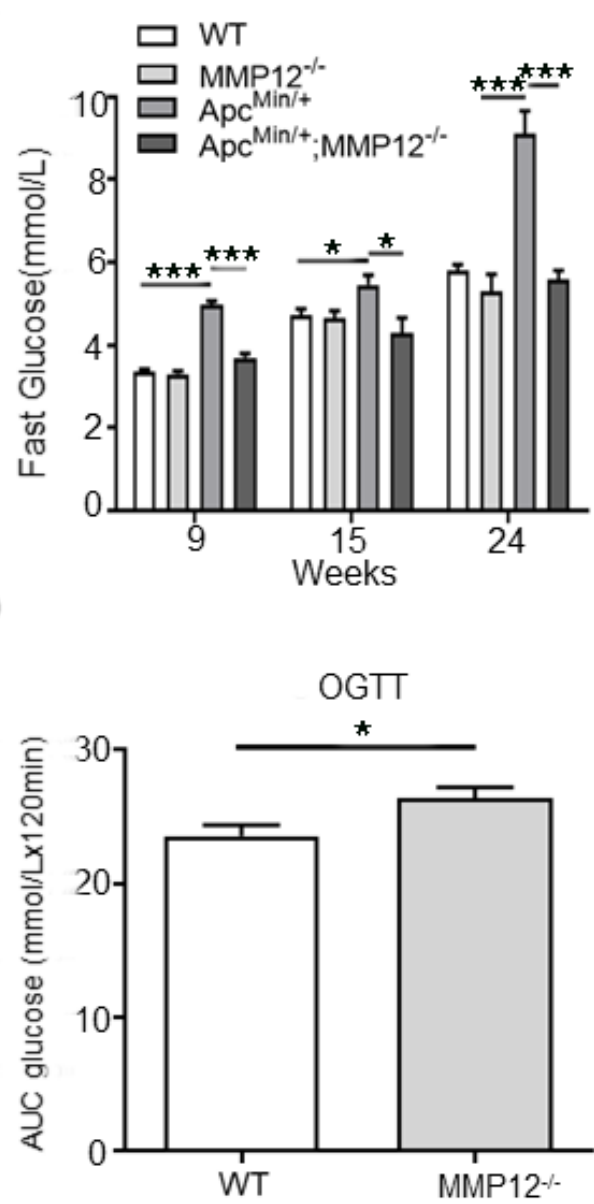

G

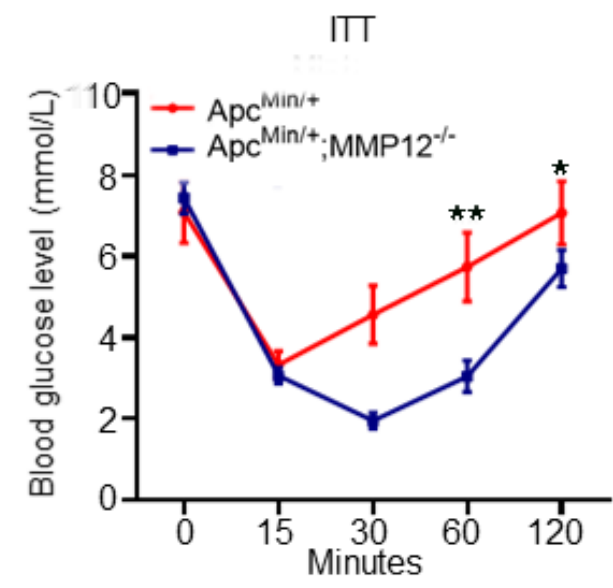

J

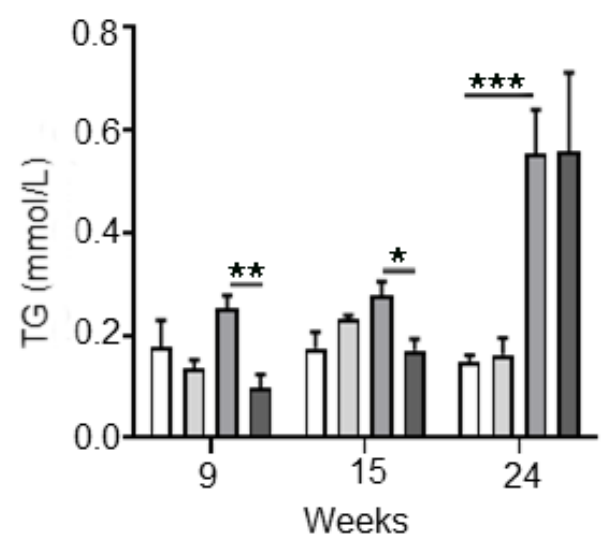

B

C

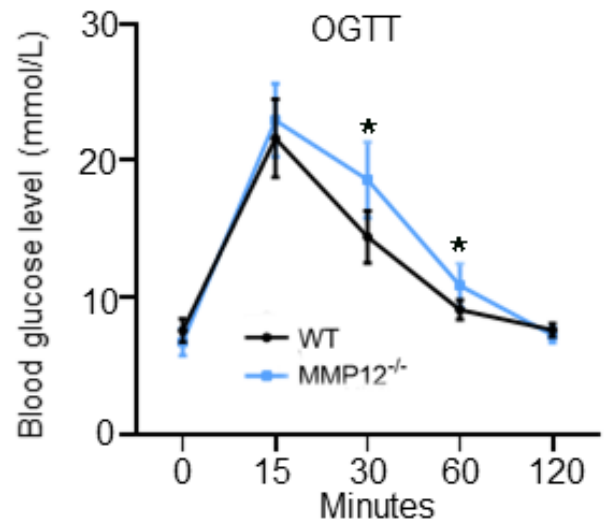

E
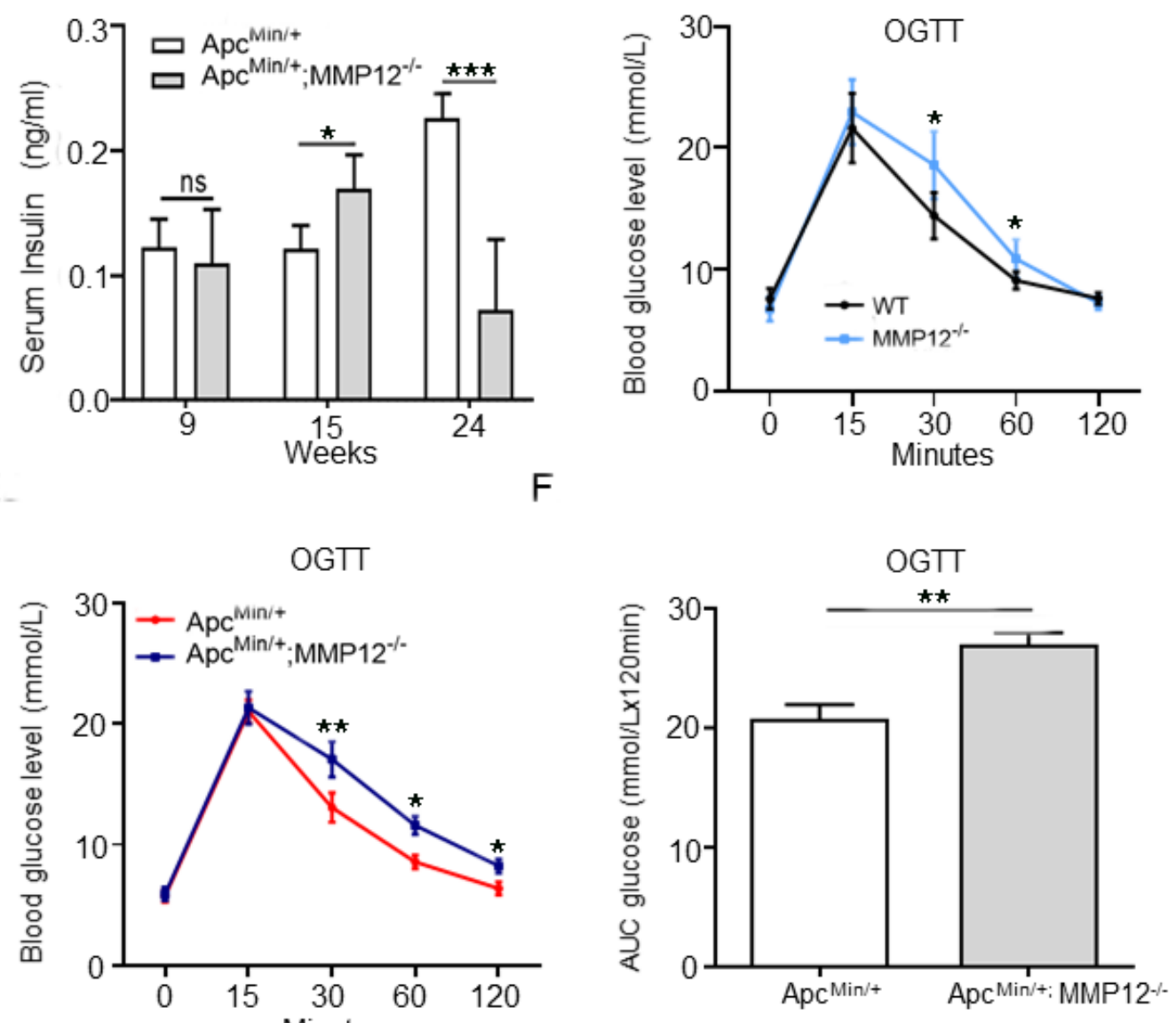

$\mathrm{H}$
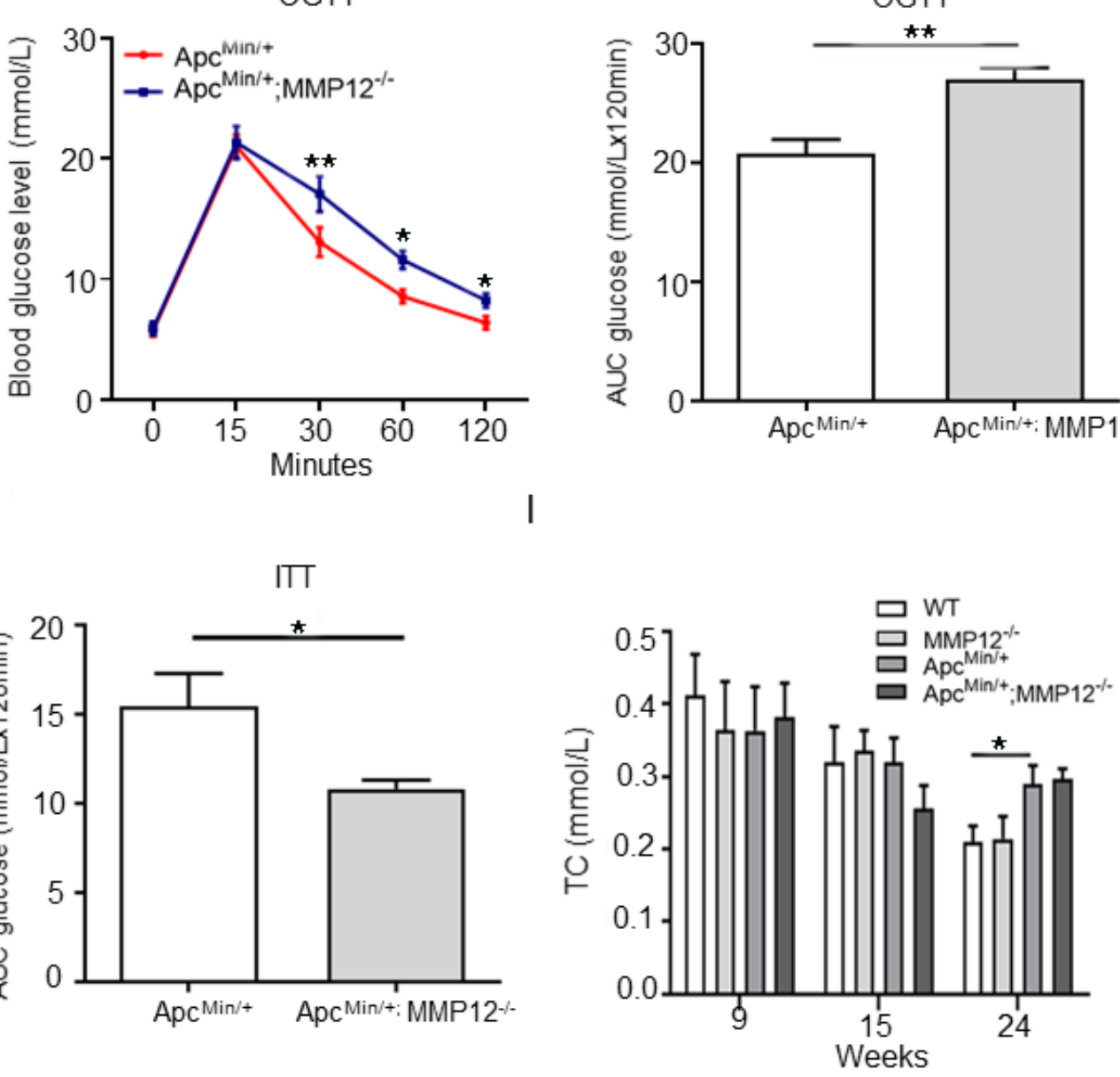

K
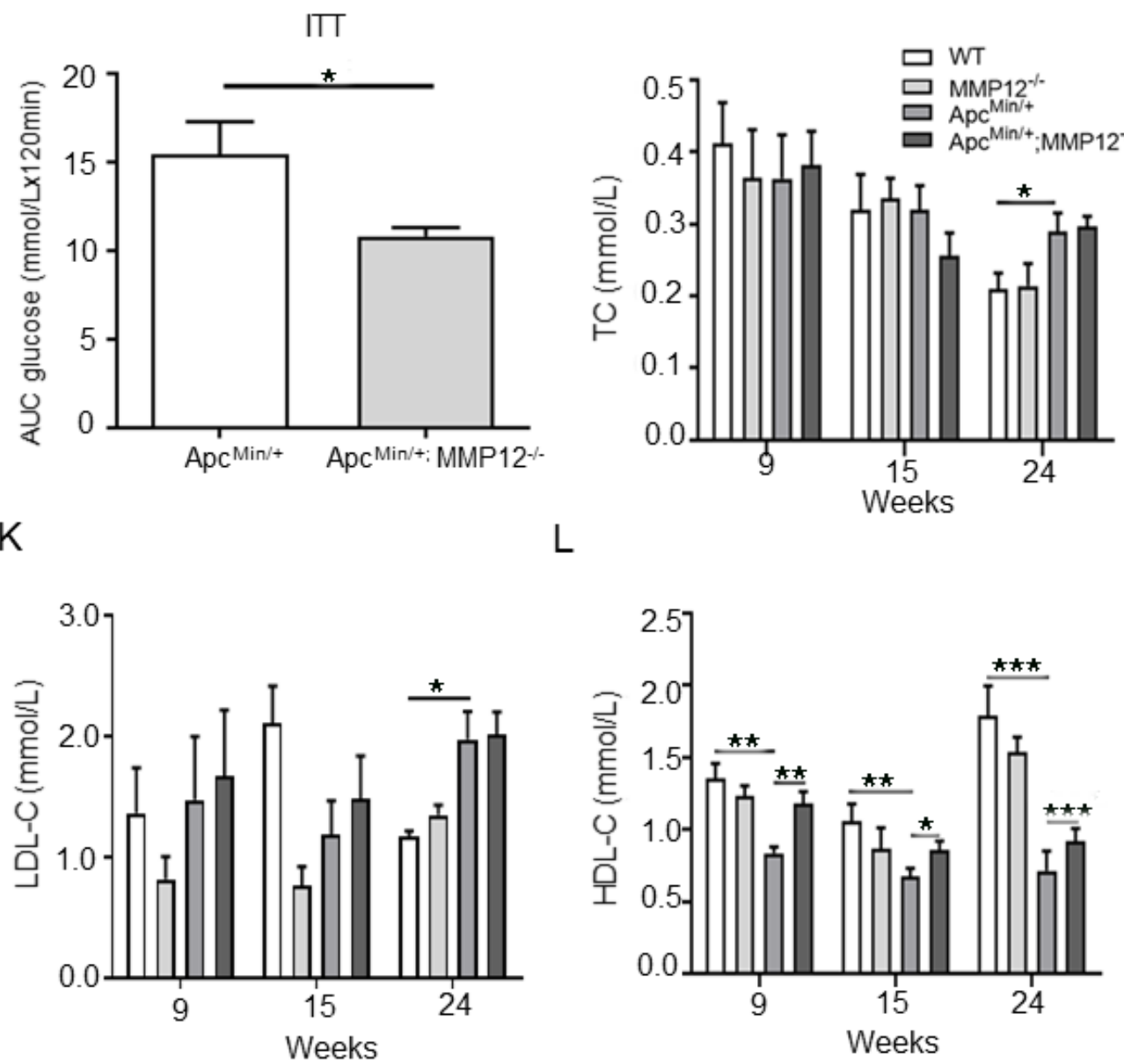
Figure S7

Cytokine Assay

\begin{tabular}{|c|c|c|c|c|}
\hline $\begin{array}{c}\text { BLC } \\
(\mathrm{CXCL13})\end{array}$ & $\begin{array}{l}\text { CD30 Ligand } \\
\text { (TNFSF8) }\end{array}$ & $\begin{array}{l}\text { Eotaxin-1 } \\
\text { (CCL11) }\end{array}$ & $\begin{array}{c}\text { Eotaxin-2 } \\
\text { (MPIF-2/CCL24) }\end{array}$ & $\begin{array}{l}\text { Fas Ligand } \\
\text { (TNFSF6) }\end{array}$ \\
\hline $\begin{array}{l}\text { Fractalkine } \\
(\mathrm{C} \times 3 \mathrm{CL} 1)\end{array}$ & GCSF & GM-CSF & IFN-gamma & $\begin{array}{c}\text { IL-1 alpha } \\
\text { (IL-1 F1) }\end{array}$ \\
\hline $\begin{array}{l}\text { IL-1 beta } \\
\text { (IL-1 F2) }\end{array}$ & IL-2 & IL-3 & IL-4 & IL-6 \\
\hline IL-9 & IL-10 & IL-12 p40/p70 & IL-12 p70 & IL-13 \\
\hline IL-17A & $\begin{array}{c}\text { I-TAC } \\
(\text { CXCL11) }\end{array}$ & $\begin{array}{c}\mathrm{KC} \\
(\mathrm{CXCL} 1)\end{array}$ & Leptin & LIX \\
\hline $\begin{array}{l}\text { Lymphotactin } \\
\text { (XCL1) }\end{array}$ & $\begin{array}{l}\text { MCP-1 } \\
\text { (CCL2) }\end{array}$ & M-CSF & $\begin{array}{c}\text { MIG } \\
\text { (CXCL9) }\end{array}$ & $\begin{array}{l}\text { MIP-1 alpha } \\
\text { (CCL3) }\end{array}$ \\
\hline MIP-1 gamma & $\begin{array}{l}\text { RANTES } \\
\text { (CCL5) }\end{array}$ & $\begin{array}{l}\text { SDF-1 alpha } \\
\text { (CXCL12 alpha) }\end{array}$ & $\begin{array}{c}\mathrm{I}-309 \\
\text { (TCA-3/CCL1) }\end{array}$ & $\begin{array}{c}\text { TECK } \\
\text { (CCL25) }\end{array}$ \\
\hline TIMP-1 & TIMP-2 & TNF alpha & $\begin{array}{c}\text { TNF RI } \\
\text { (TNFRSF1A) }\end{array}$ & $\begin{array}{c}\text { TNF RII } \\
\text { (TNFRSF1B) }\end{array}$ \\
\hline
\end{tabular}

